(ISSN:2149-2751)

2 (3), pp. $58-79$

http://www.ijoks.com

\title{
Education and improvement of Kurdish written language: some newspapers and magazines of the beginning of 20th century as examples
}

\author{
Halmat Baiz Rasool ${ }^{I}$
}

Received: February 01, 2016

Reviewed: March 03, 2016

Accepted: March 21, 2016

\begin{abstract}
The issues of Kurdish Language and Kurdish Language Identity has been highly evident through the beginnings of twentieth century. The significant changes that took place in political and cultural aspects in Kurdistan has gave the birth of numerous journals and magazines which clearly expressed the general circumstances of the twentieth century. This research under the title "Issue of Literacy and Kurdish Written Language in Certain Journals and Magazines in the Early Twentieth Century" aims to provide a wide analysis on the related issues expressed through the common journals and magazines. The research covers five journals and magazines issued between1920-1932 and shades light on a number of efforts done by the Fourth Power (Power of Journalism) to highlight the language and Kurdish language study issues as a national privileges after the effects caused by the division of Kurdistan, Iraqi Government establishment and the British policy in the region. The common challenges can be literacy encouragement, spelling, language purification and requests to solve schools' problems, and these challenges will be the discussing topics in the research. There are many external and internal factors that caused the given challenges, that's why the writers and journalists boldly and eagerly discussed the challenges and were part of the solutions by giving suggestions and pointing the weaknesses through various techniques and evidences.
\end{abstract}

Recommended citation:

Rasool, H. B. (2016). Education and improvement of Kurdish written language: some newspapers and magazines of the beginning of 20th century as examples. International Journal of Kurdish Studies 2 (3), 58-79.

${ }^{1}$. Lecturer, Department of Kurdish language, Faculty of art, Soran University, Soran Erbil, Kurdistan Region - F.R. Iraq. email; Halmat.rasool@soran.edu.iq 


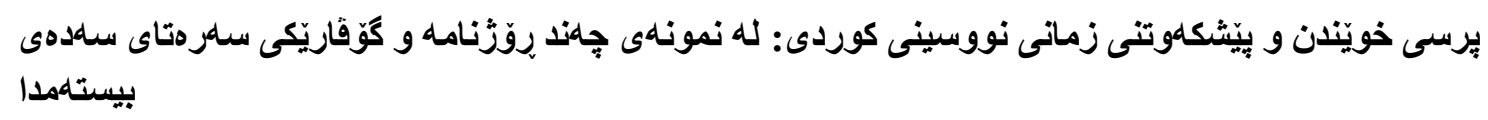
هلْمّمت بايز رِمسول

\section{بِيَّنهى}

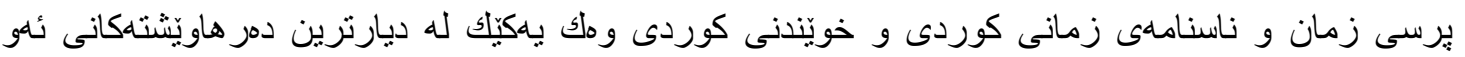

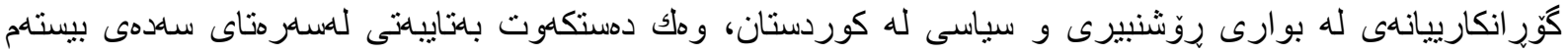

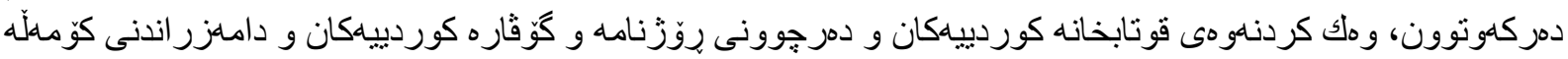

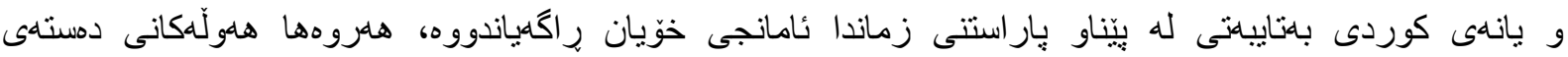

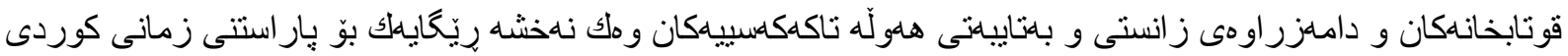

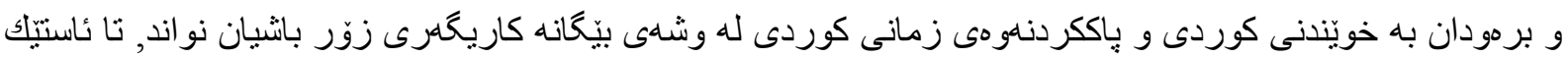

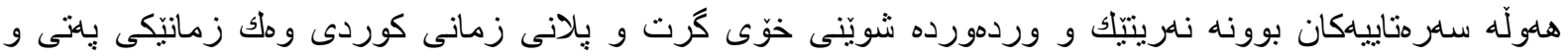
كاريخهر هاتهكايهوه.

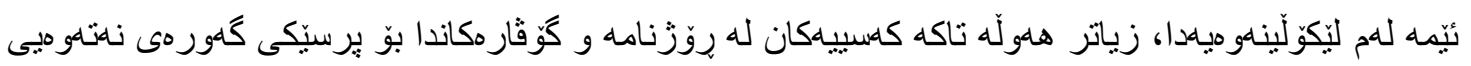

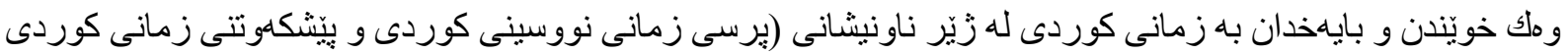

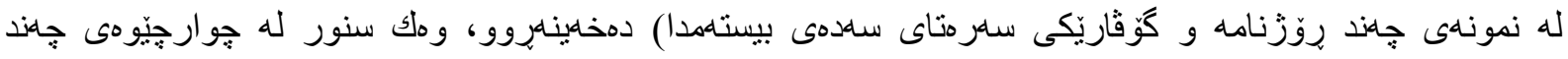

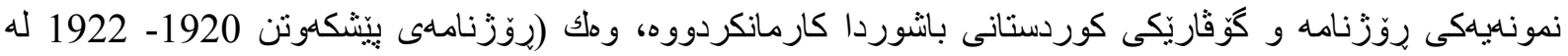

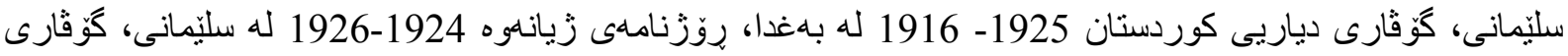

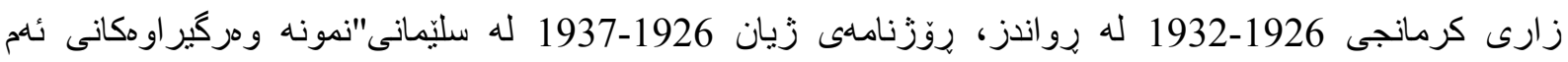

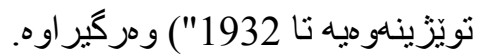

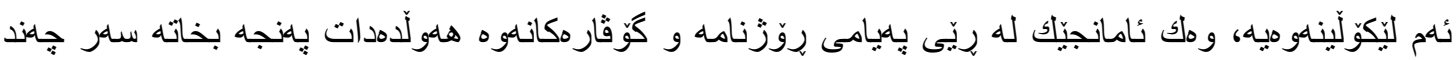

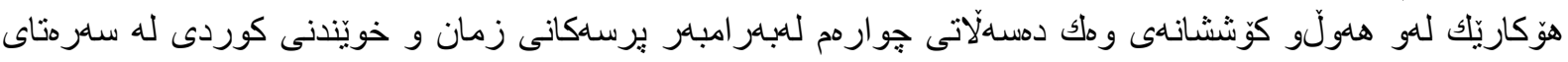

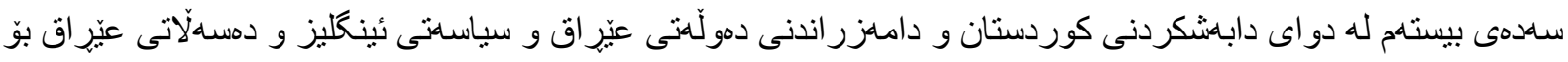

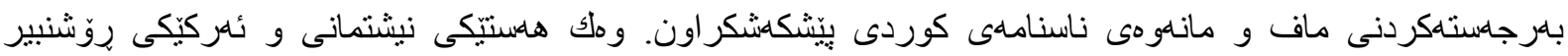

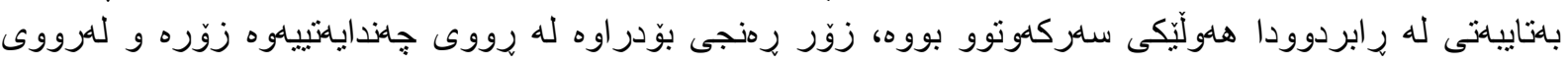

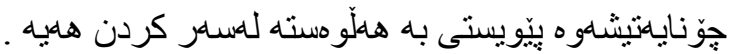

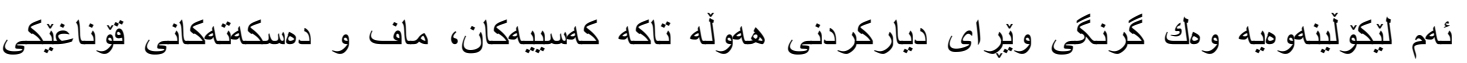

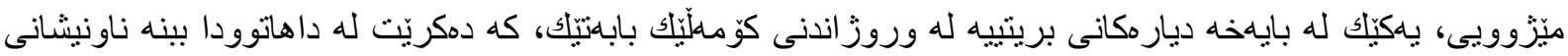

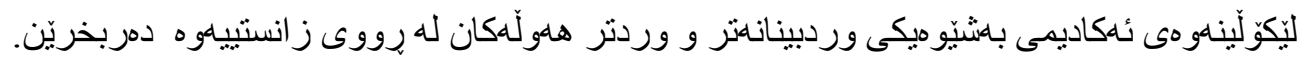

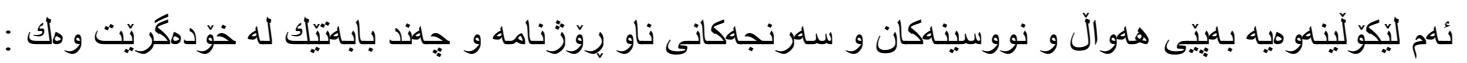

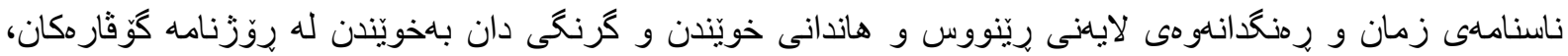

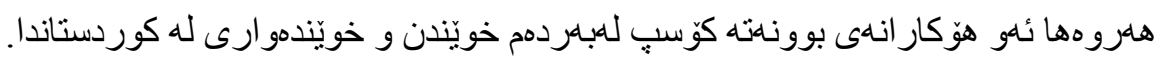




\section{ردكاه سلرهتاييهكانى برسبى زمان و خويَندنى كوردى}

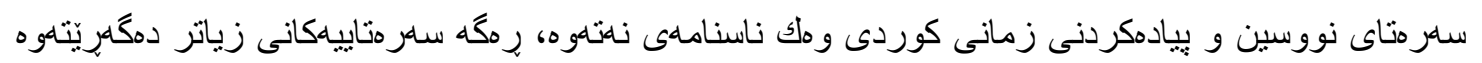

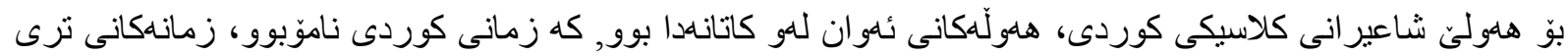

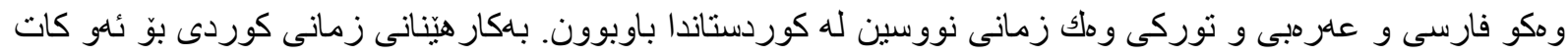

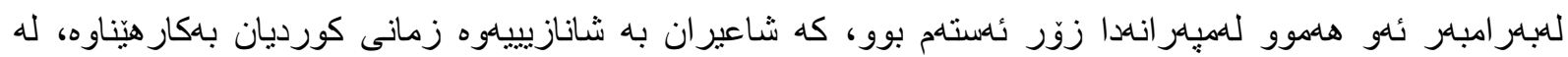

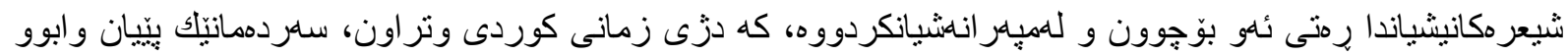

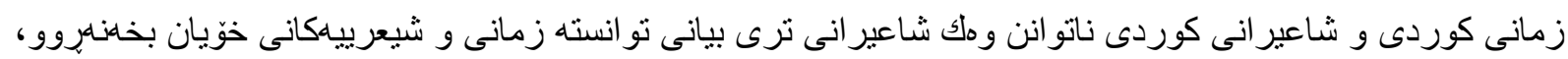

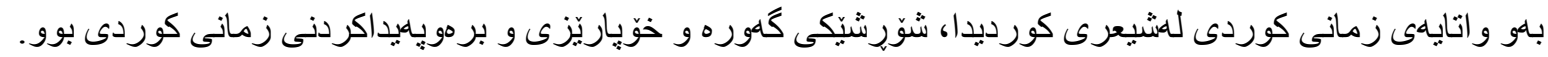

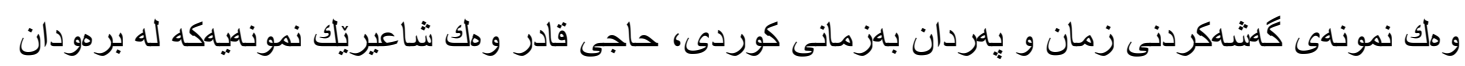

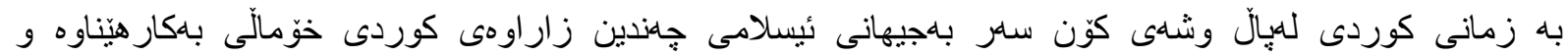

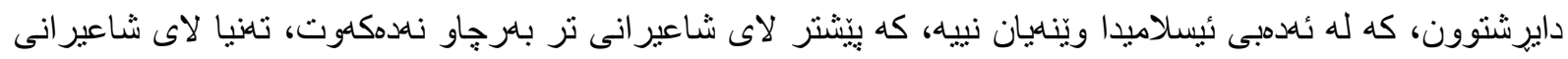

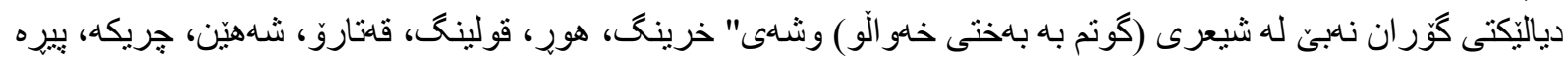

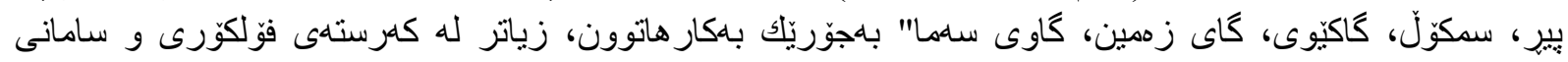

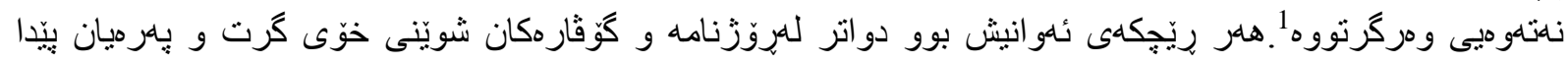

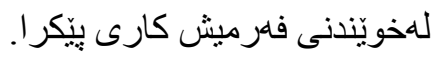

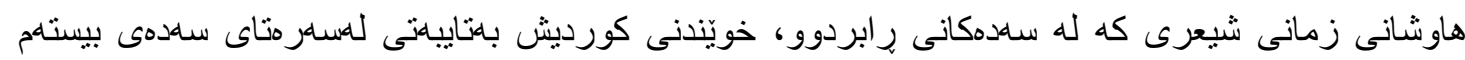

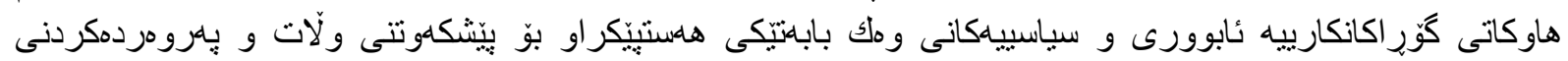

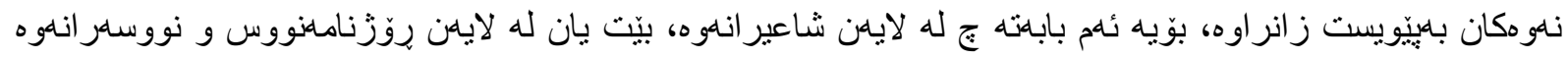

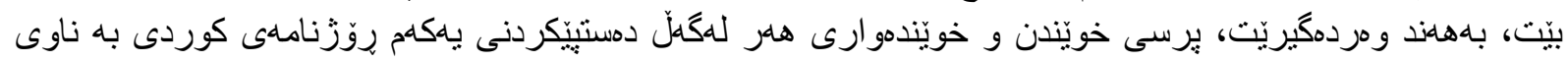

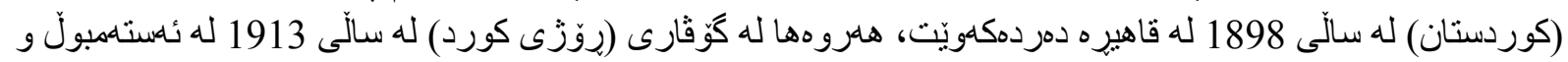

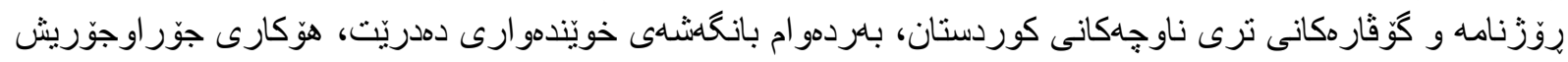

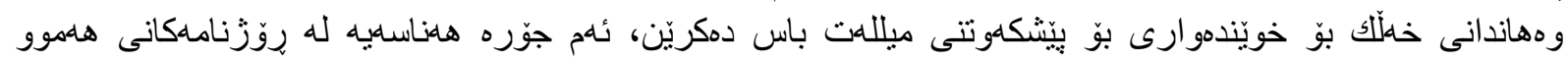

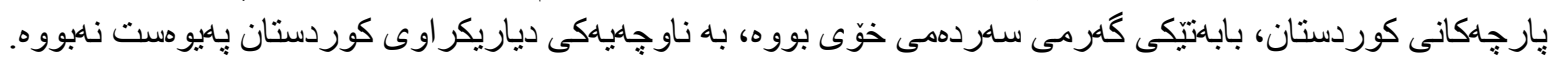

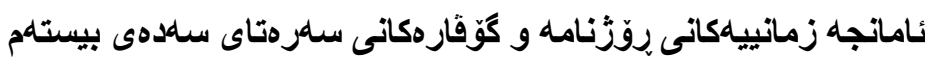

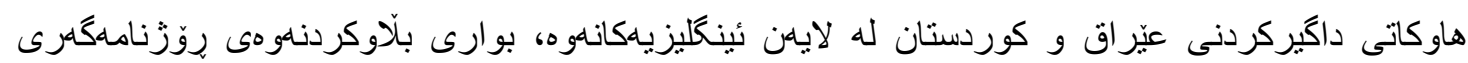

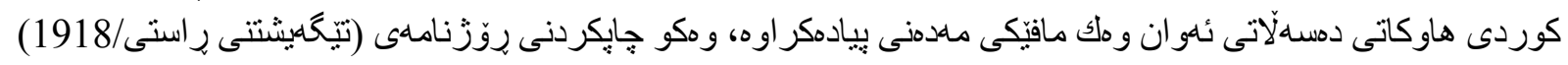

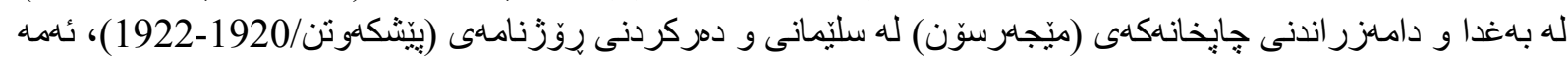

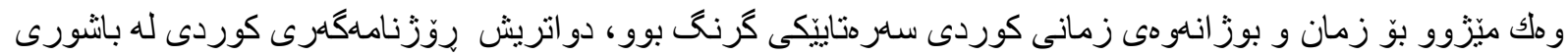

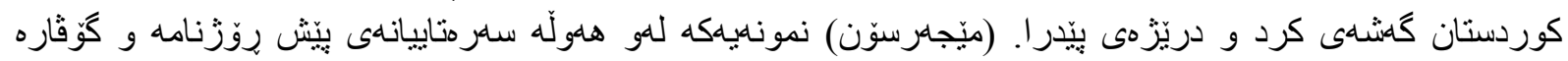

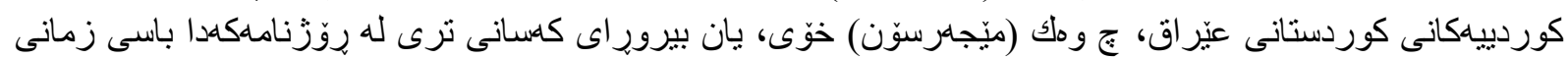

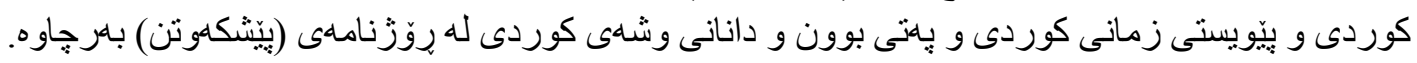

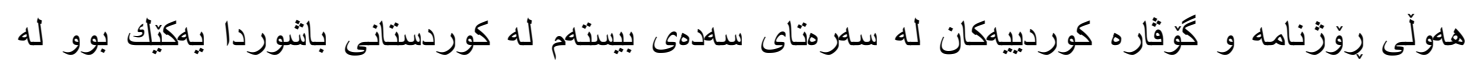

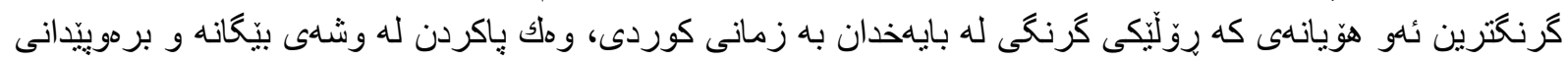

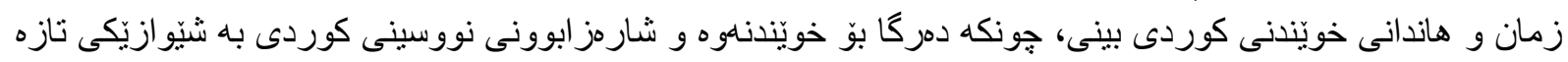

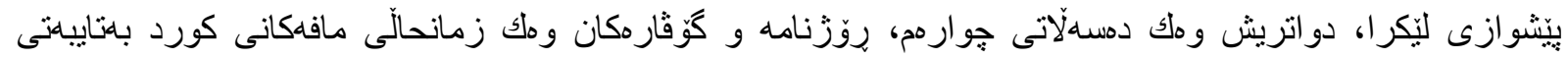

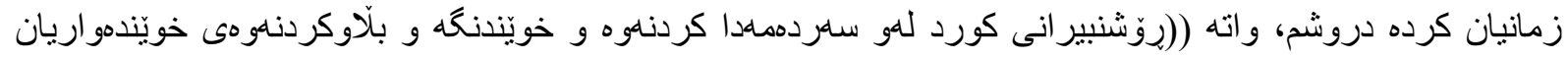

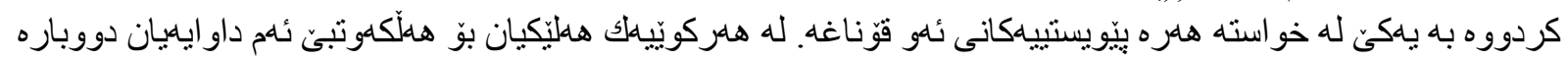

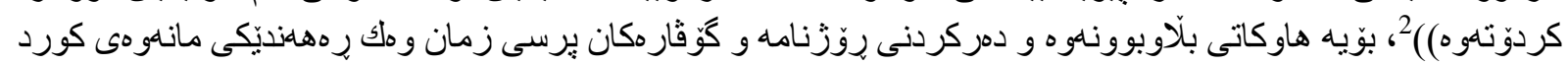

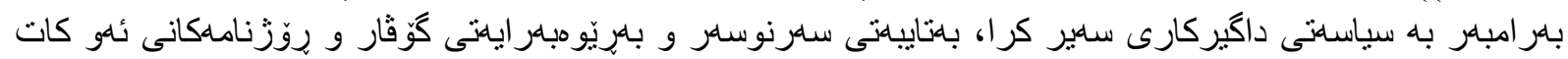

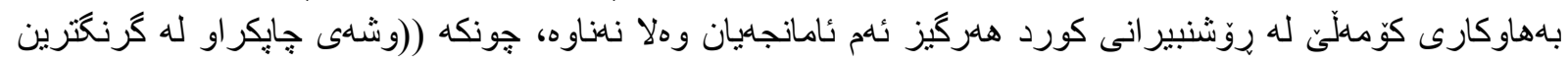




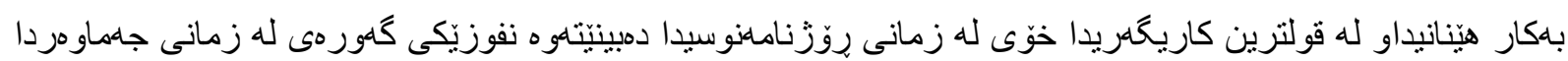

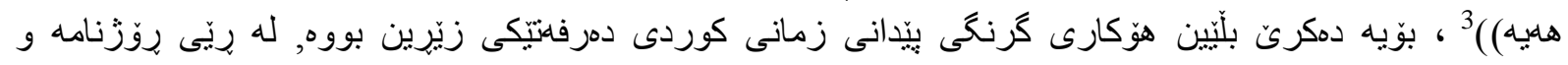

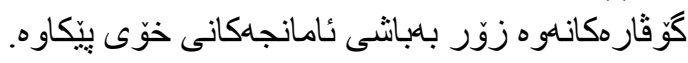

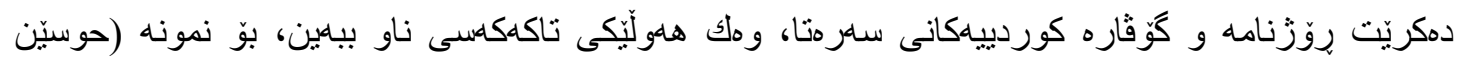

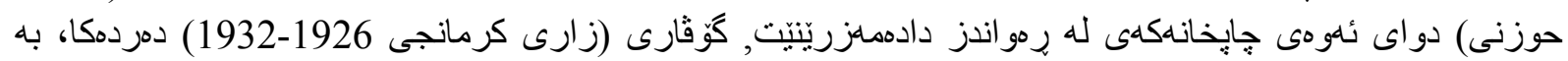

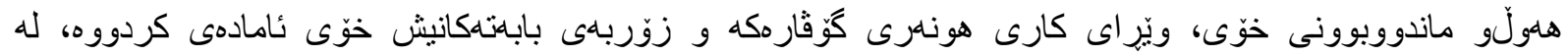

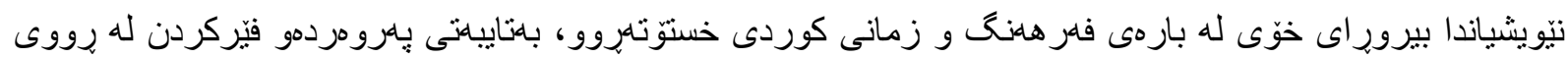

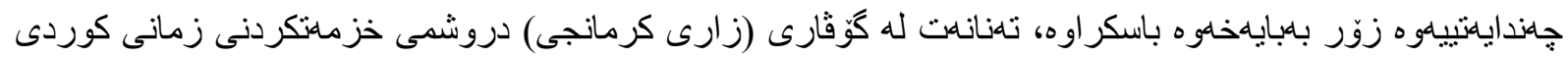

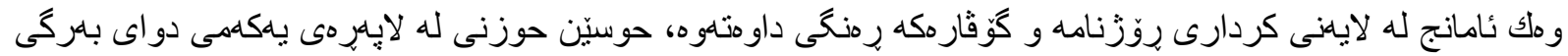

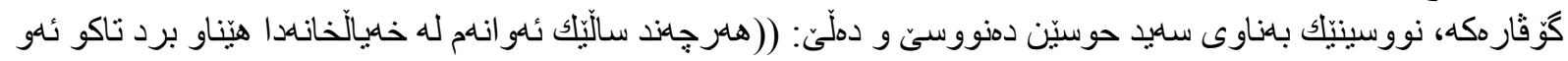

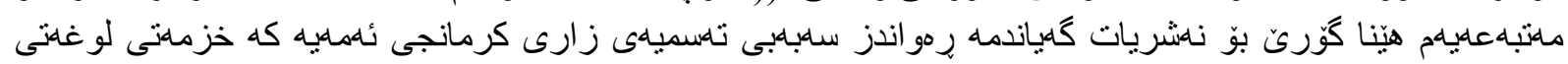

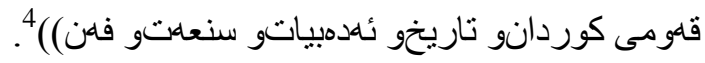

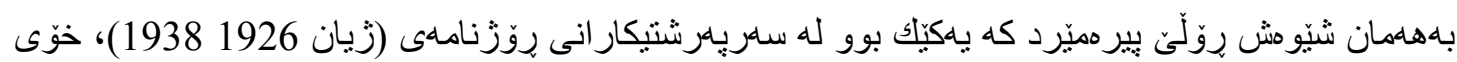

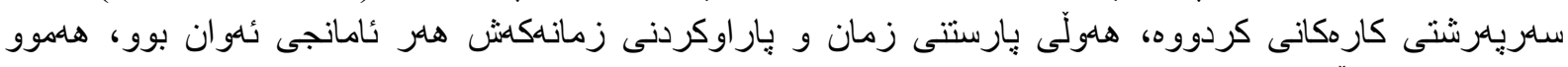

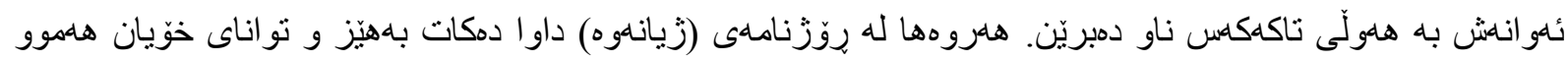

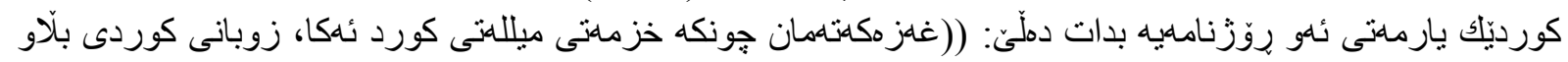

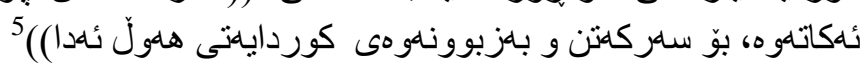

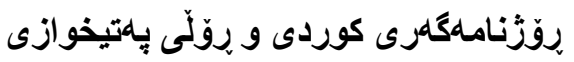

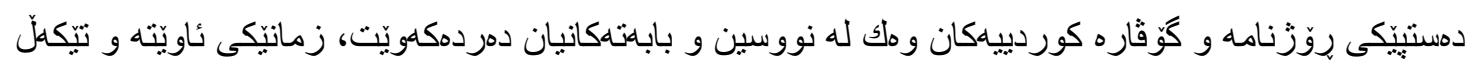

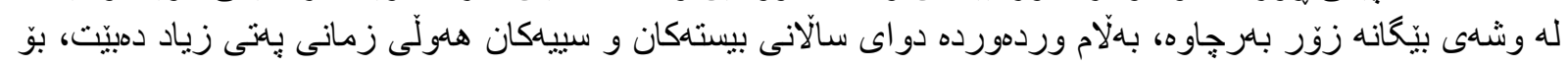

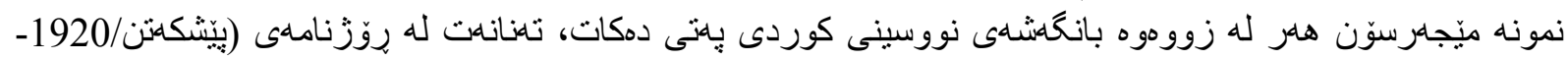

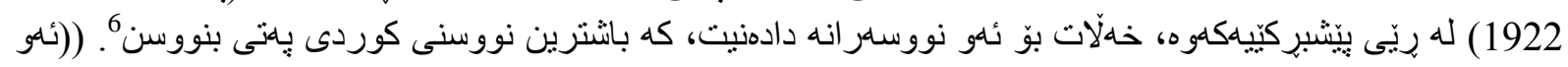

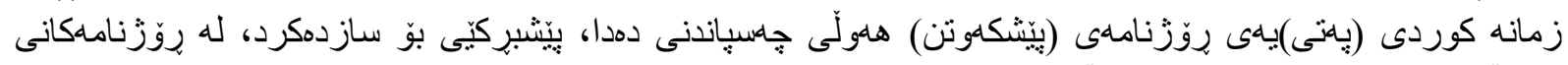

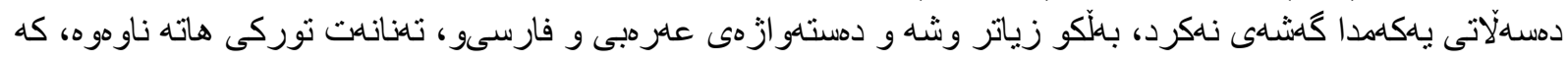

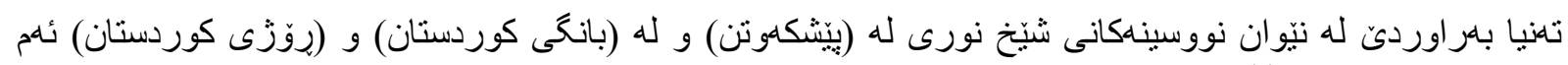

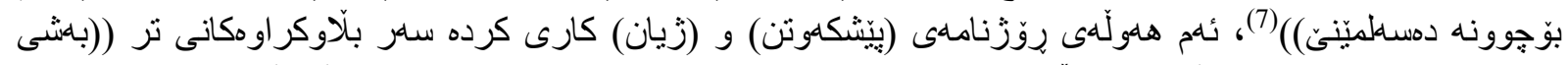

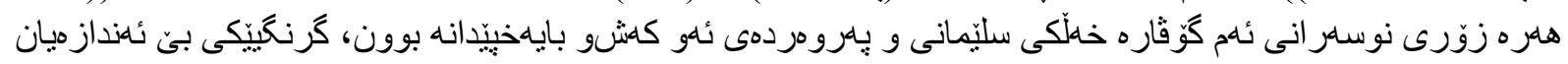

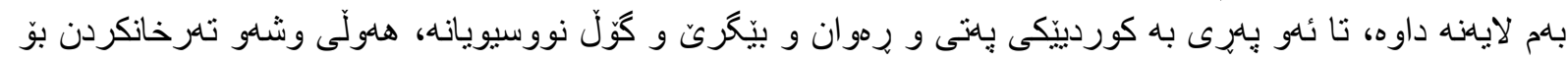

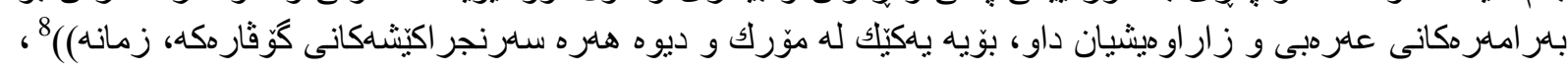

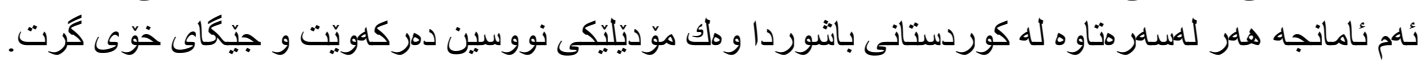

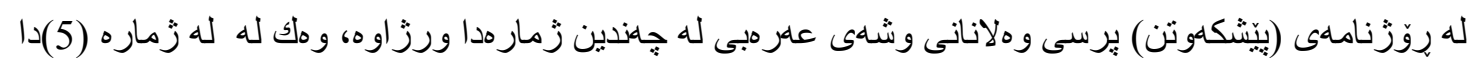

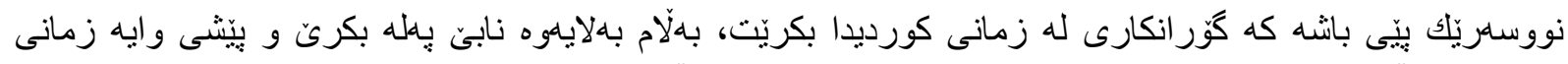

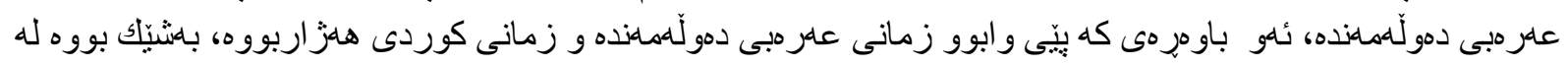

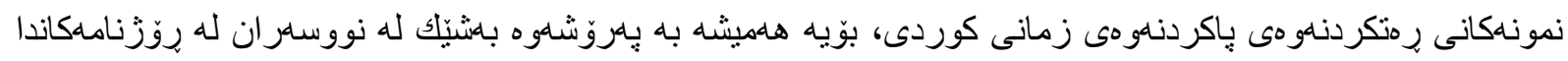

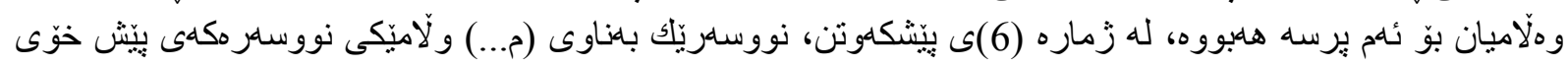

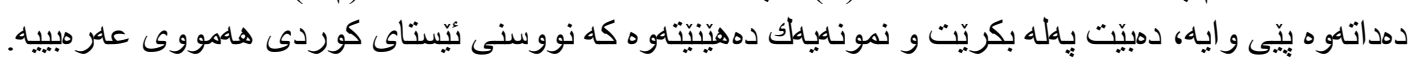

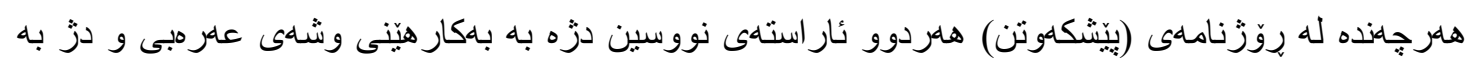

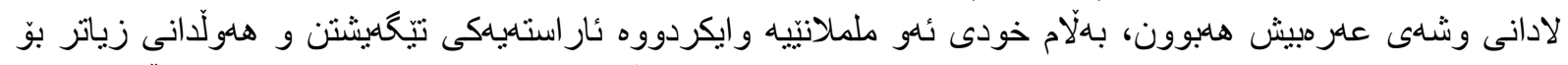

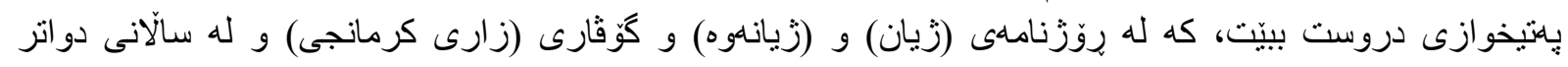




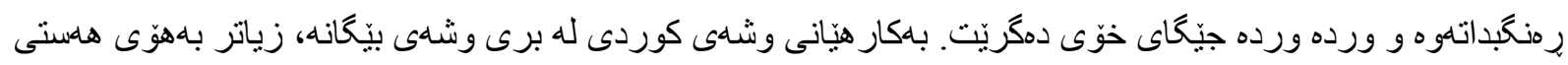

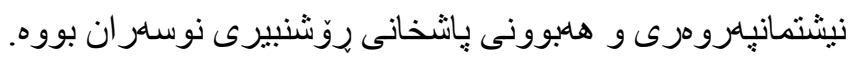

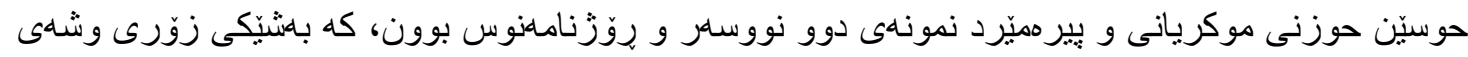

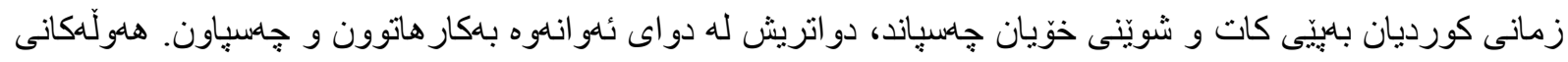

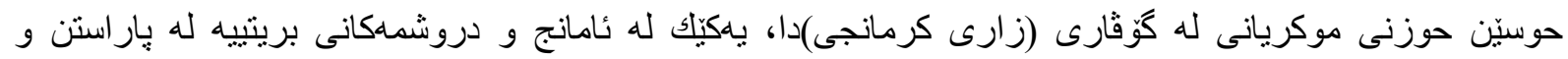

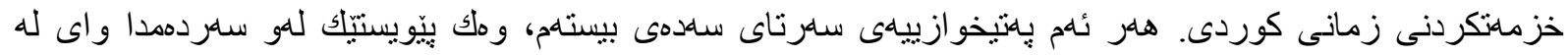

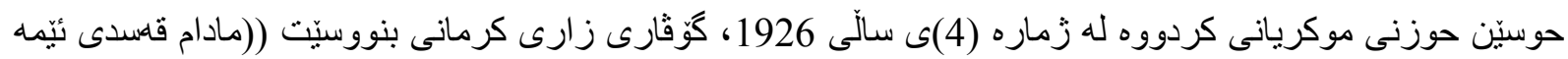

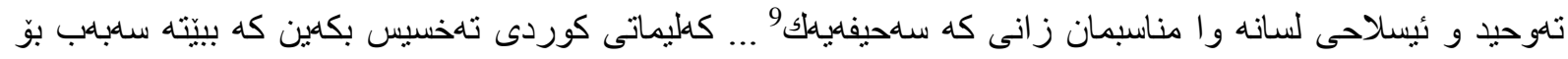

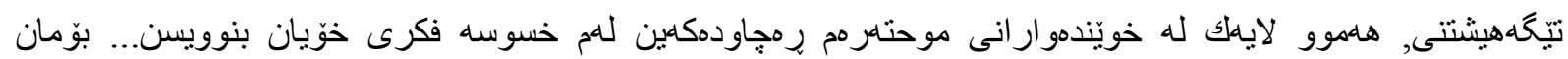

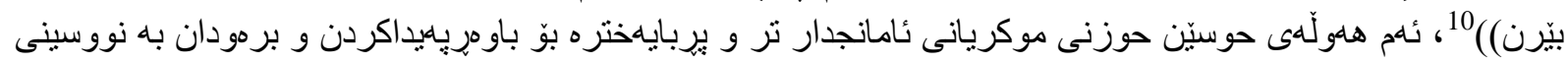

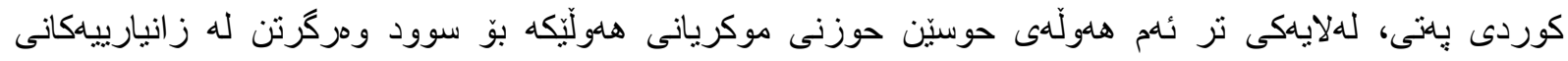

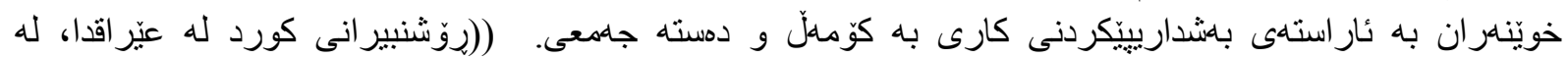

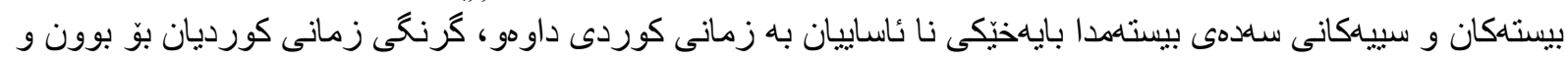

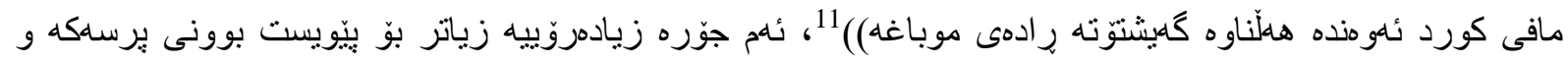

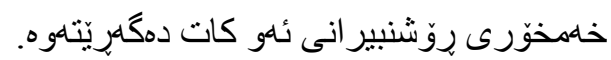

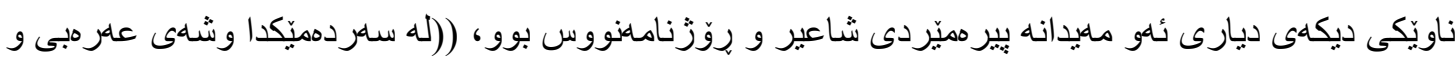

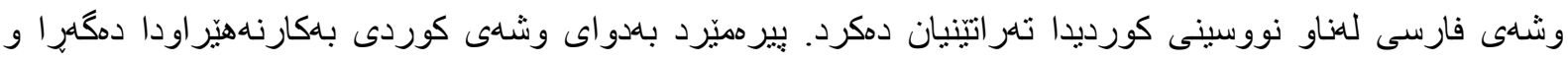

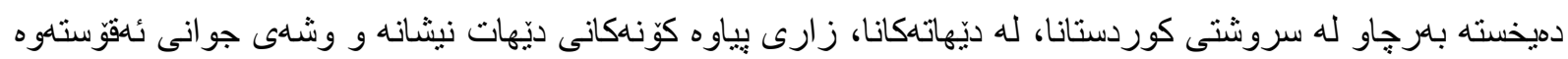

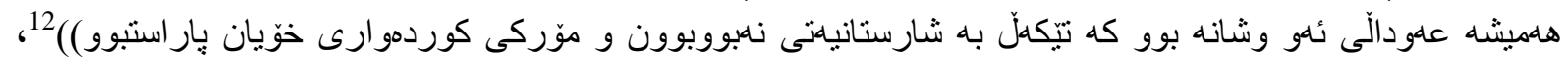

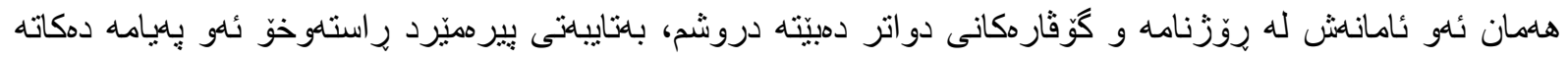

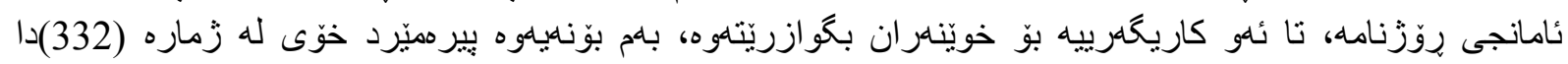

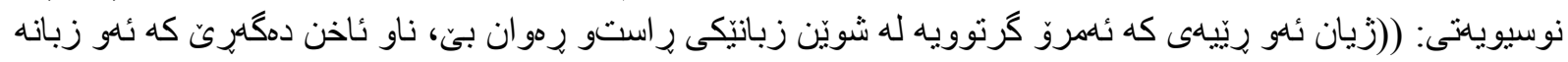

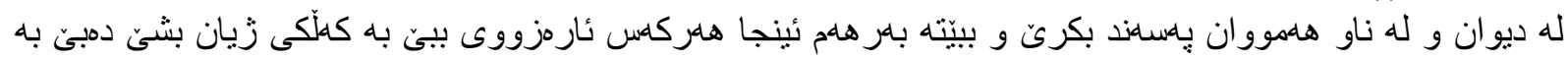

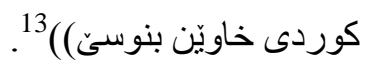

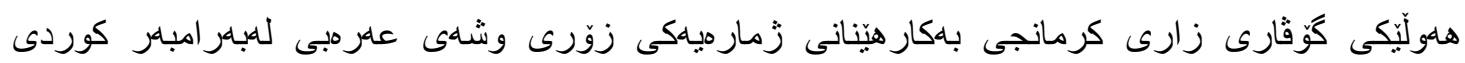

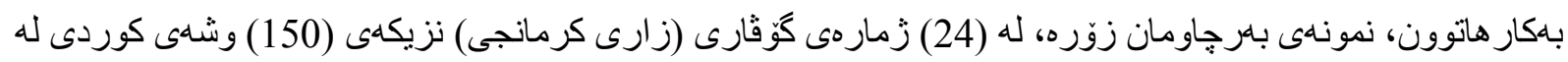

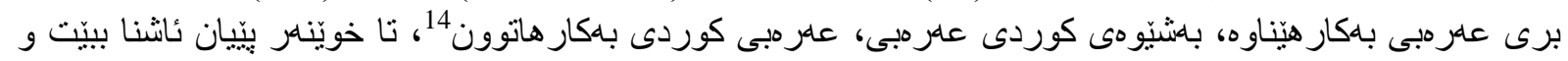

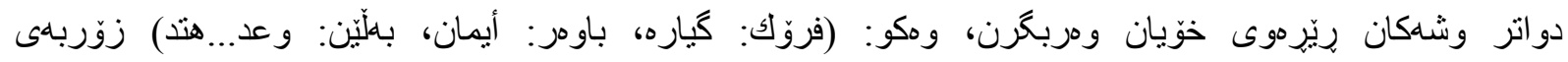

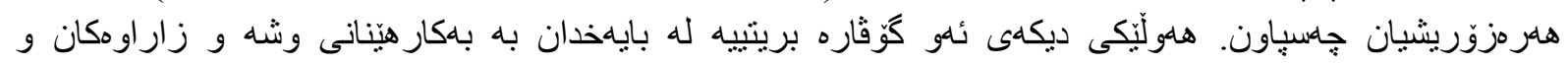

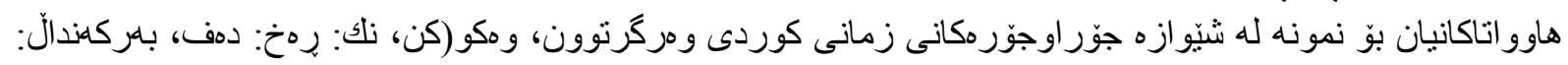

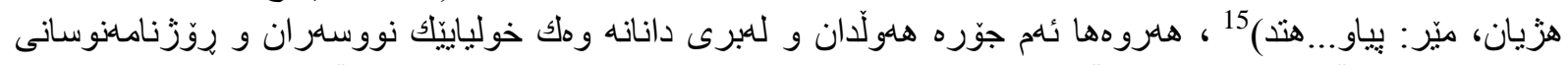

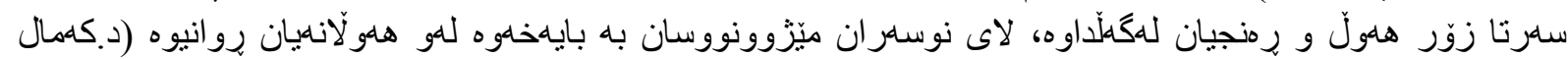

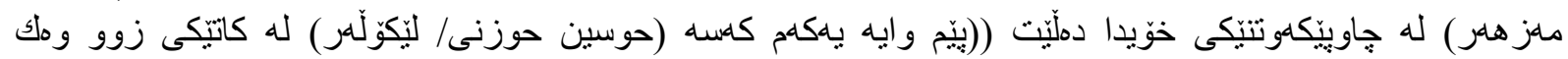

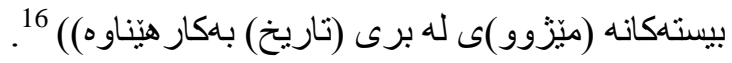

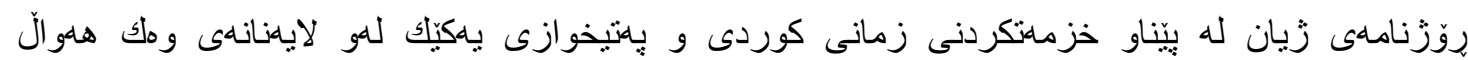

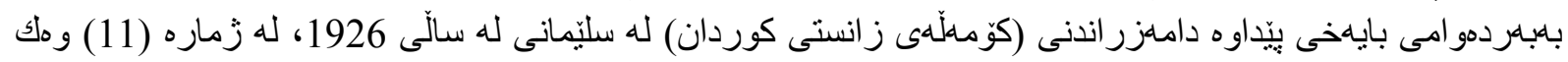

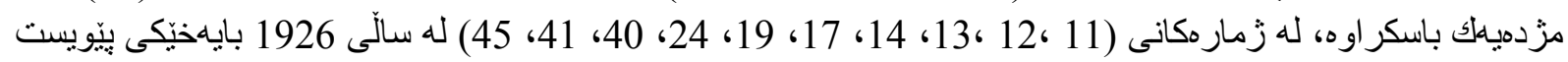

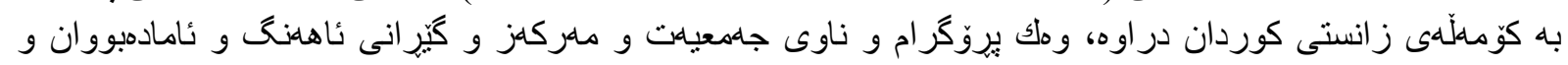

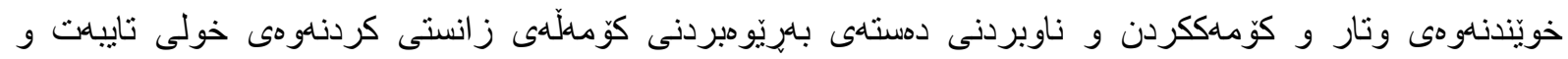

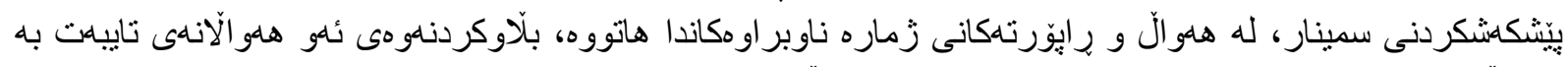

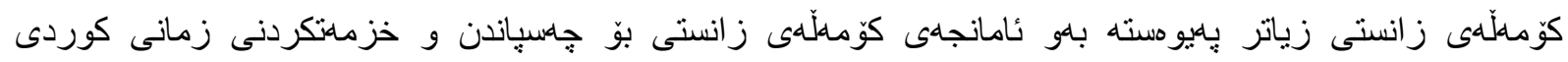




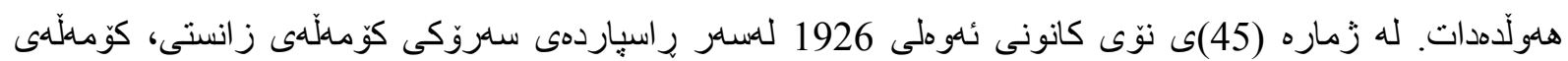

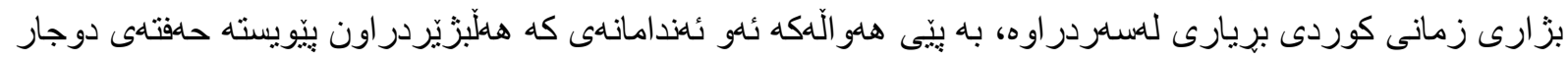

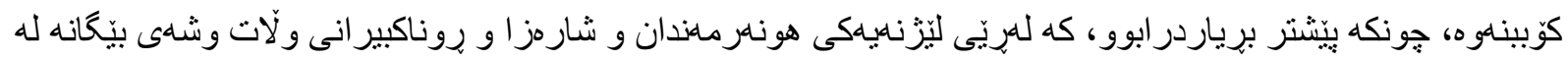

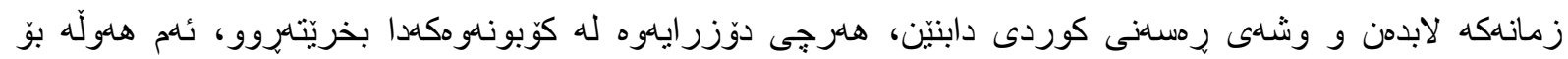

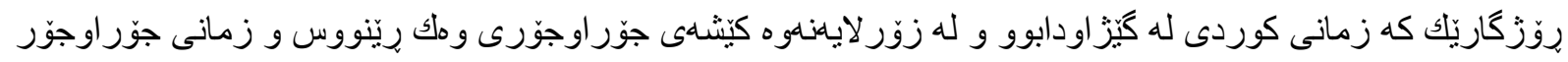

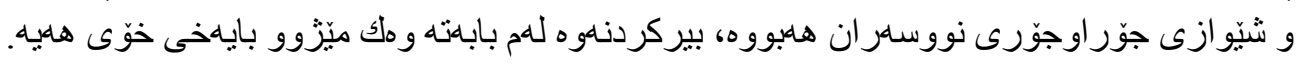

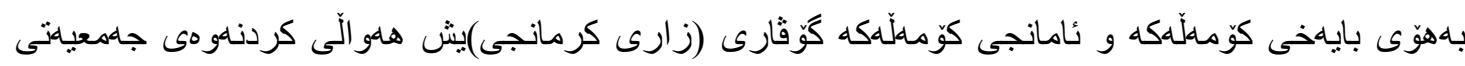

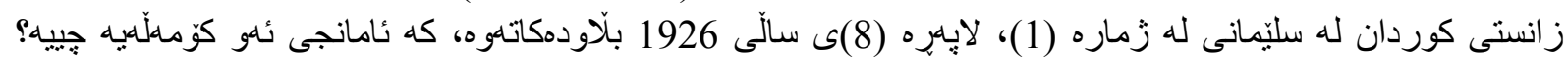

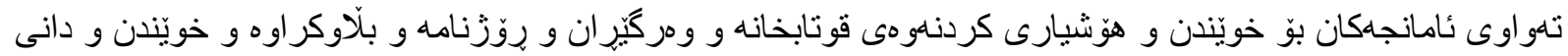

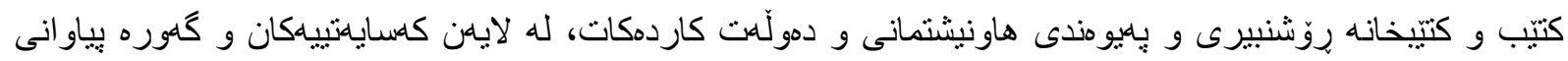

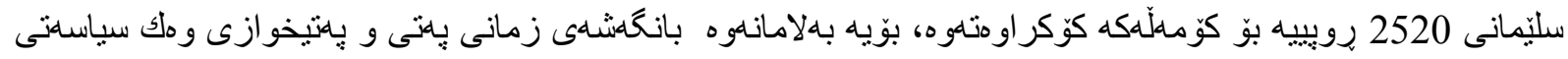

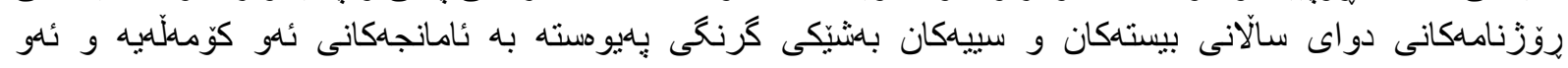

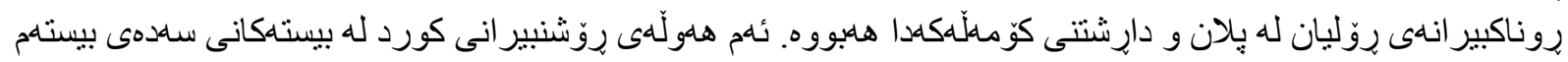

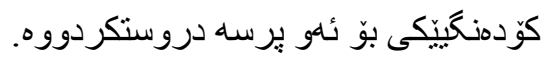

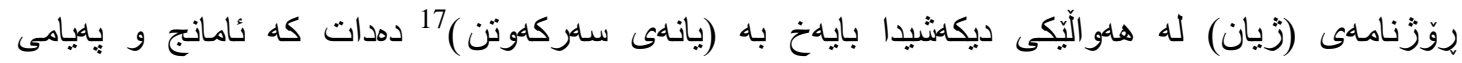

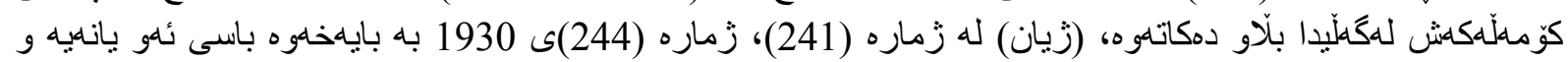

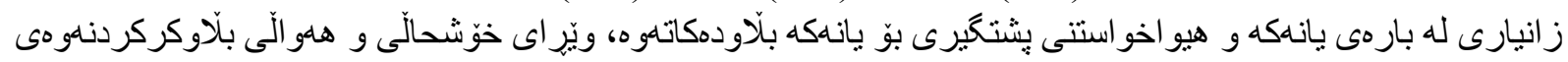

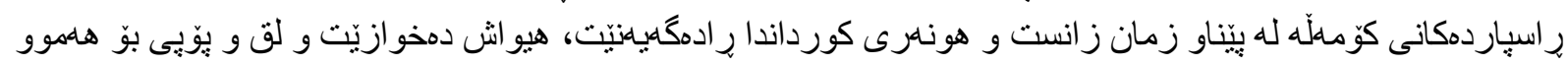

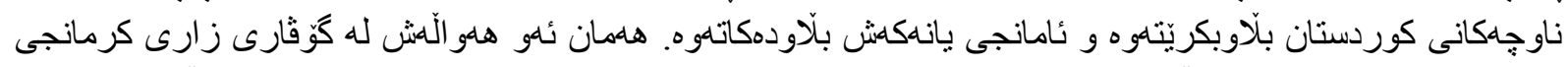

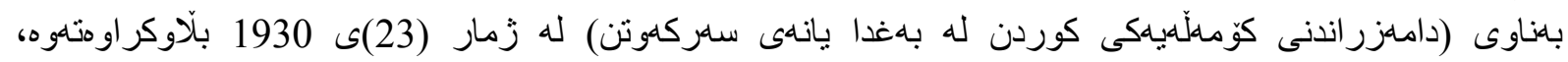

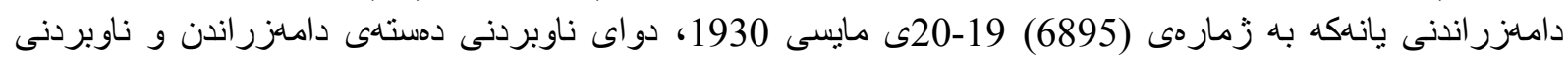

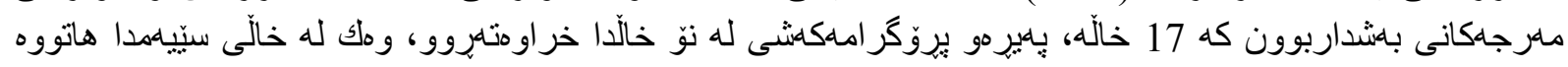

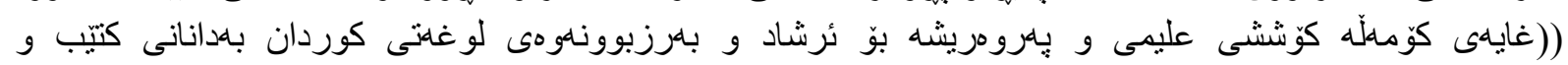

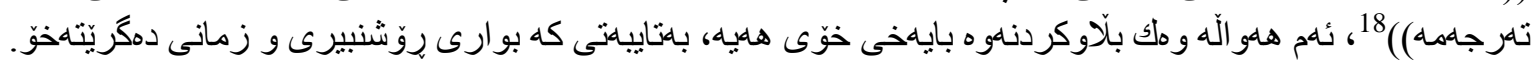

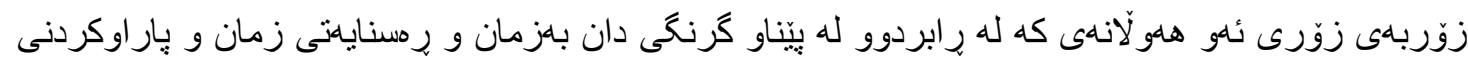

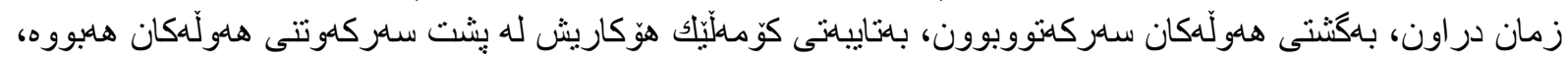

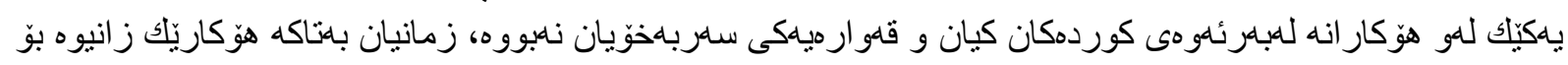

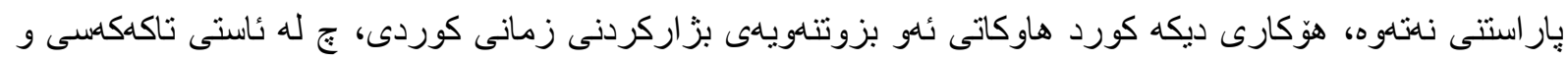

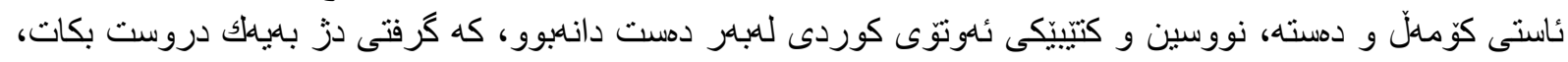

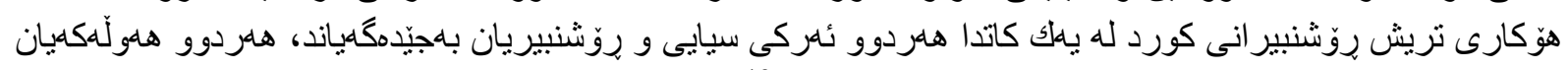

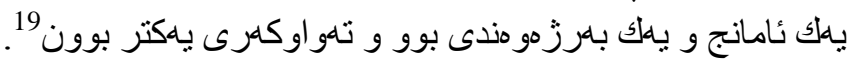

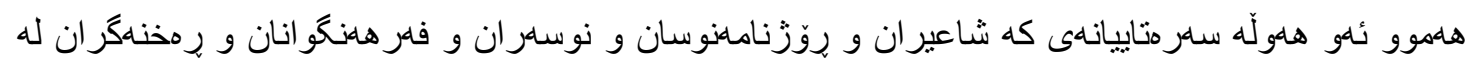

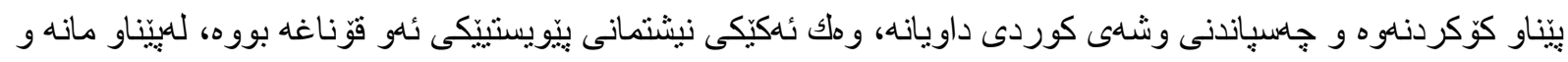

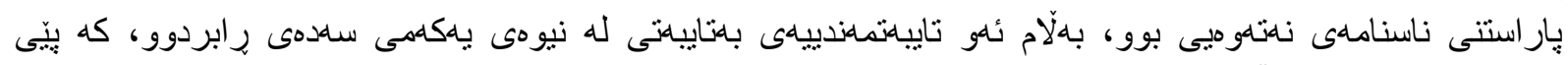

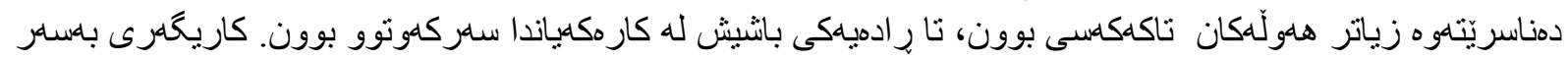

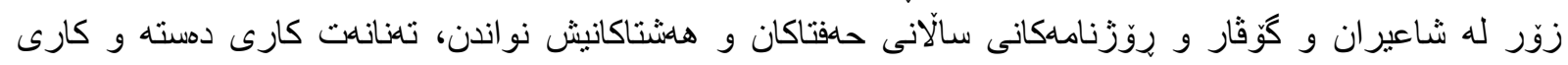
ئمكاديمشى بهدو اي خوّيدا هينّان.

\section{تهوهرهكانى بايهخدان به زمانى خويَندن و نووسين}

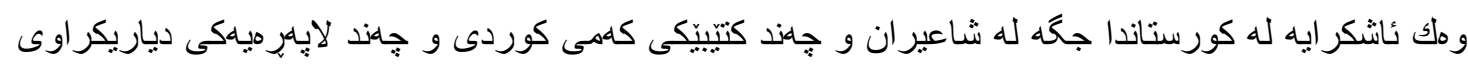

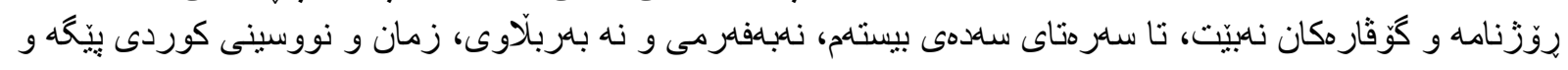




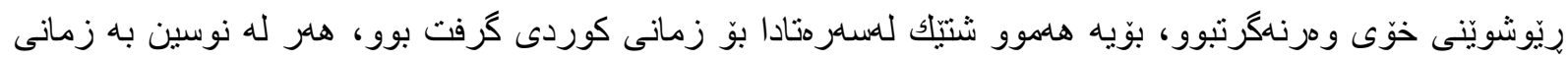

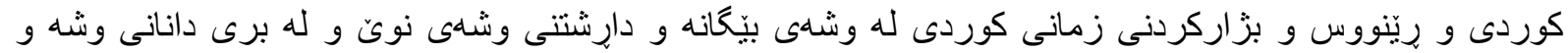

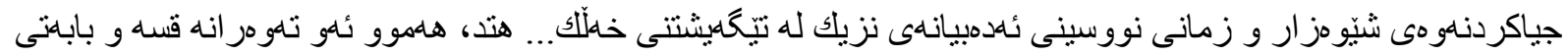

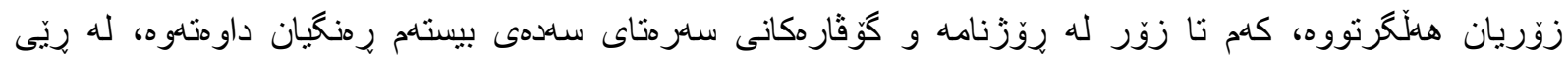

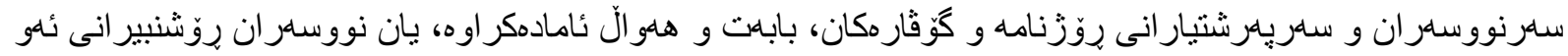

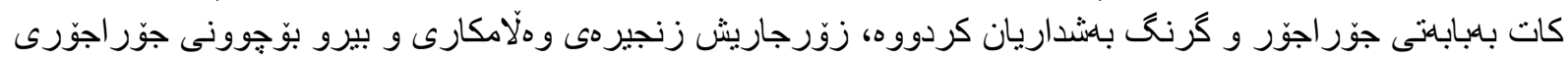

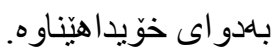

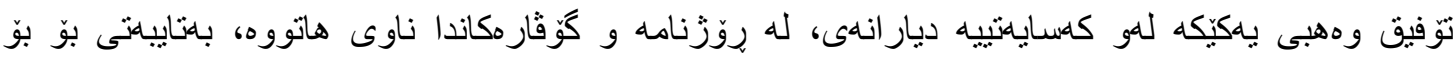

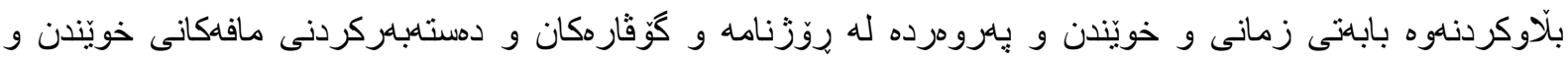

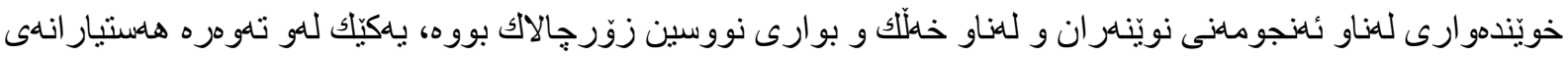

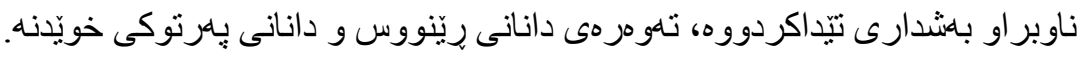

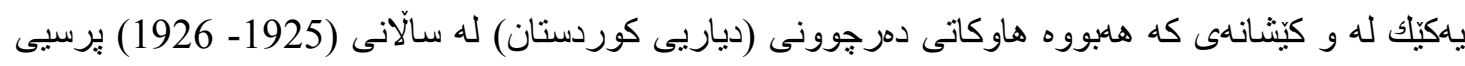

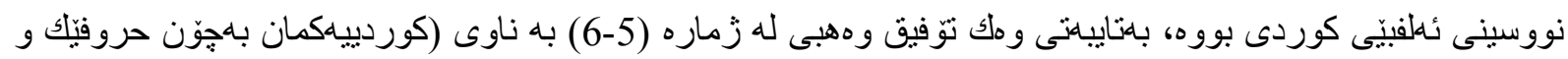

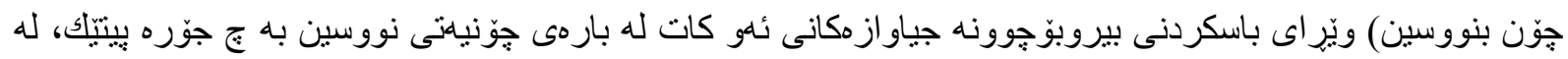

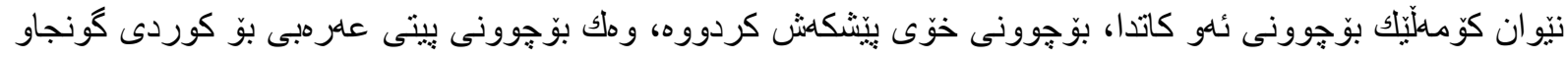

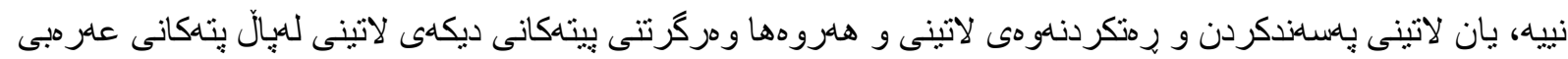

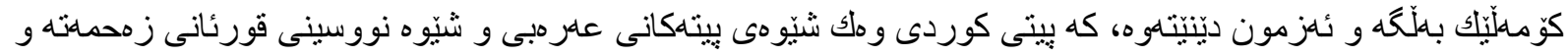

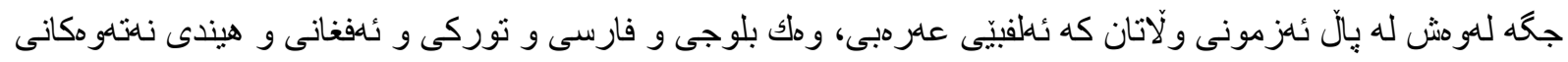

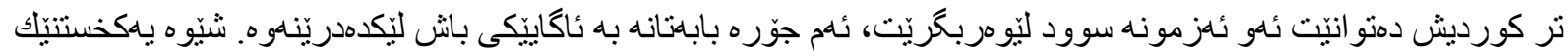

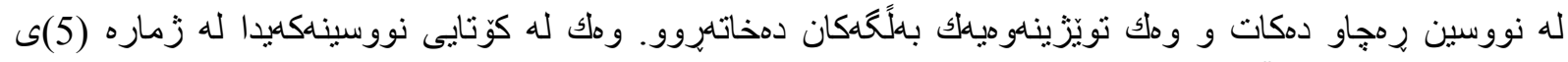

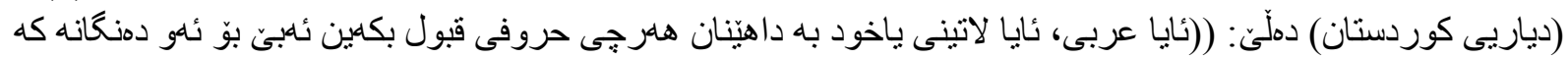

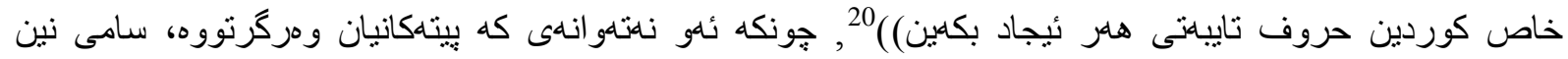

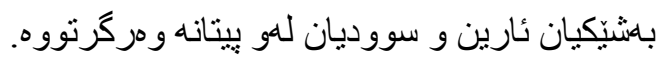

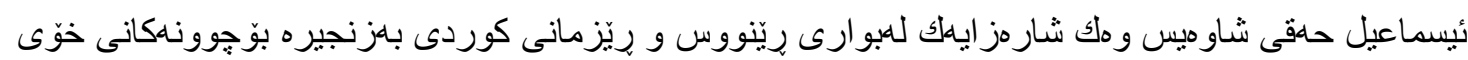

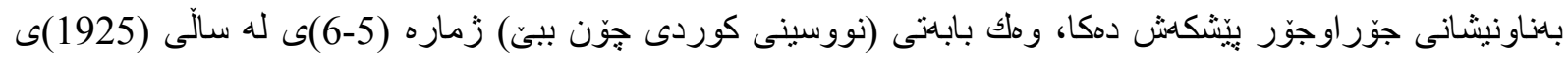

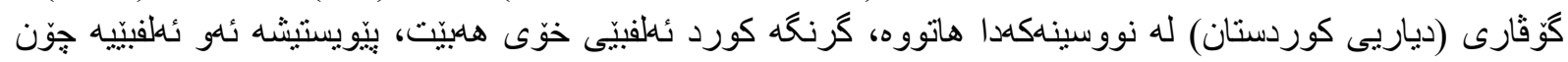

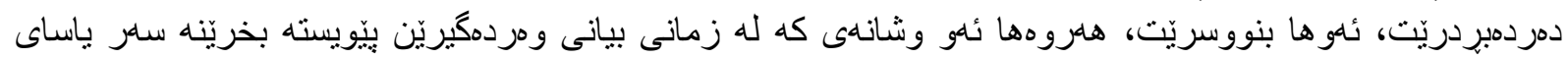

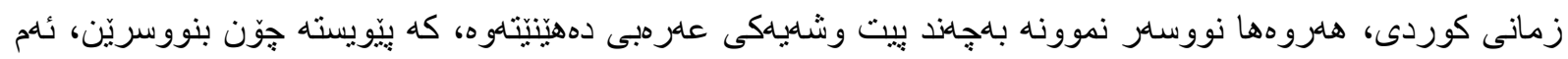

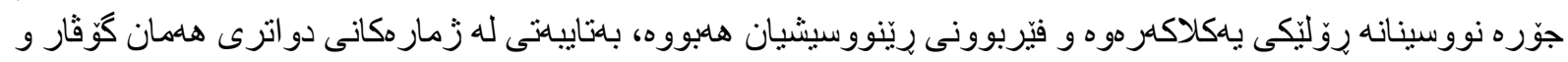

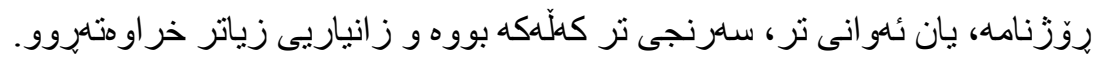

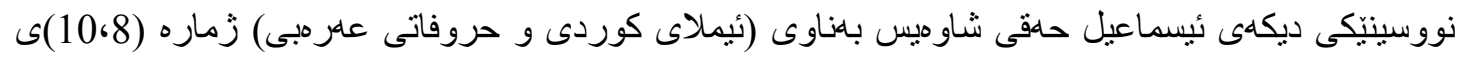

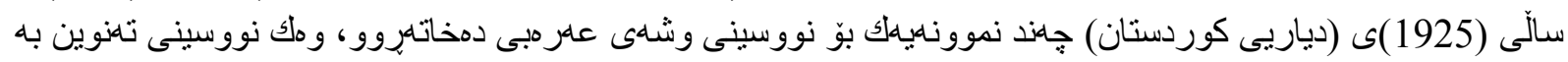

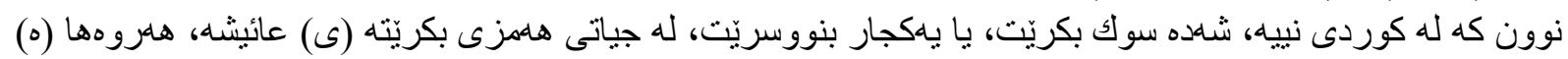

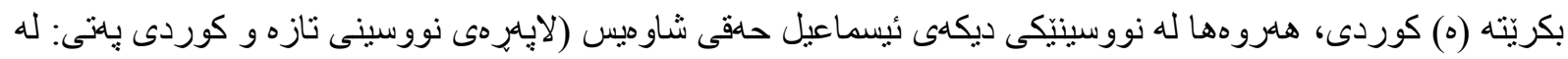

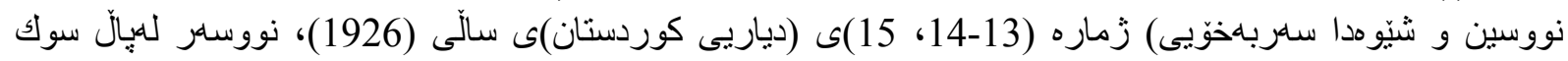

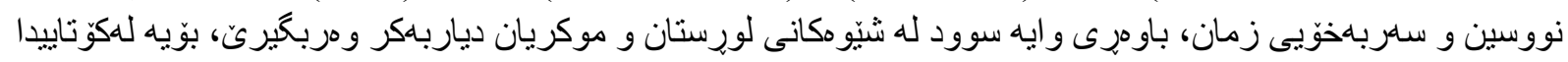

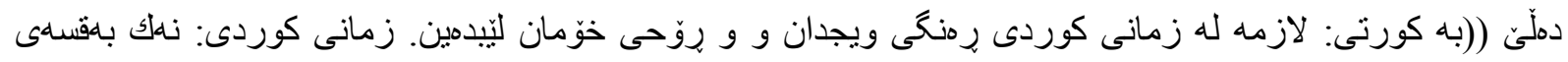

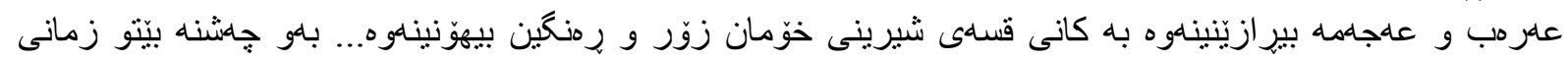

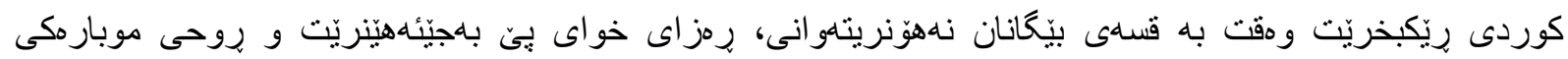

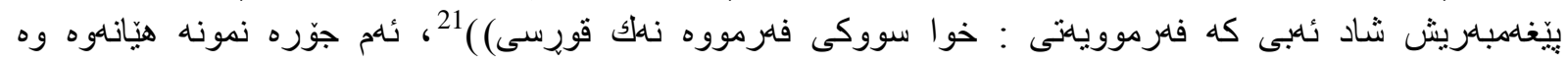




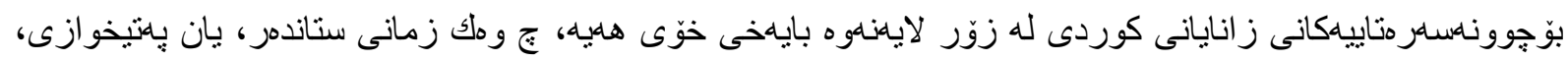

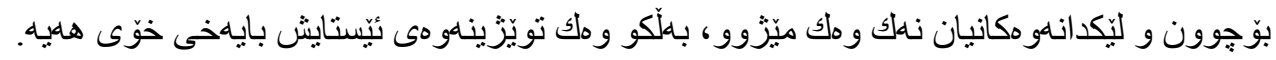

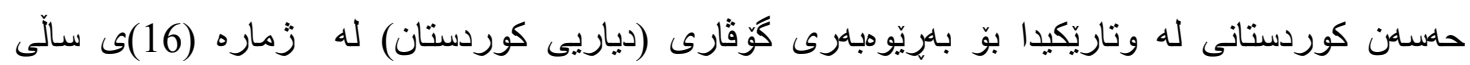

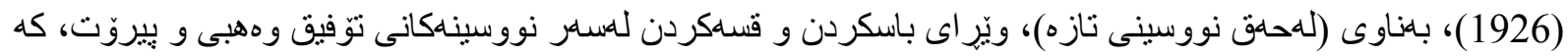

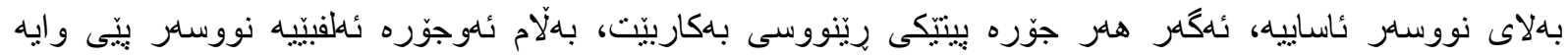

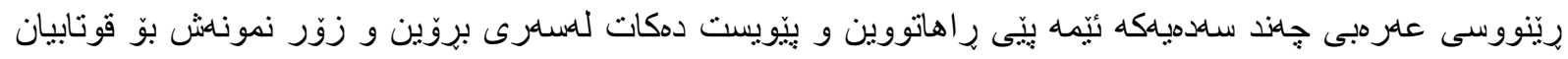

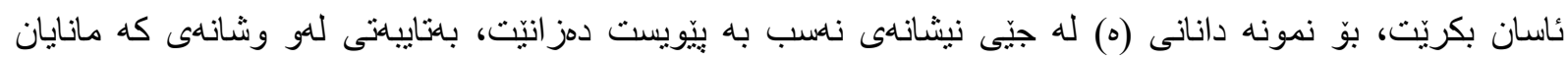

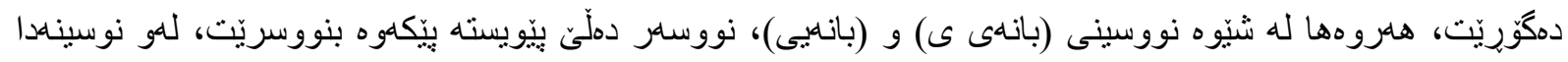

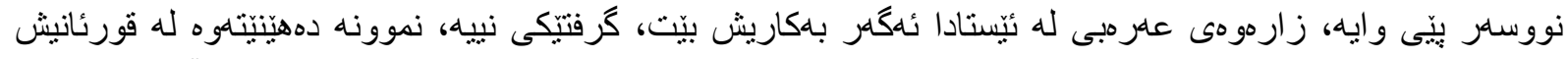

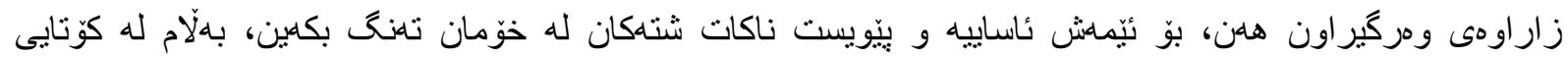

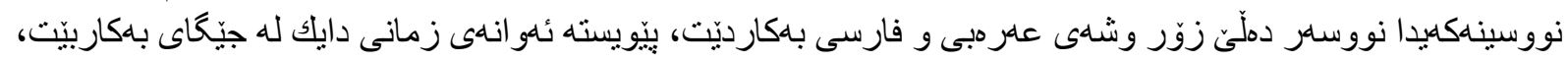

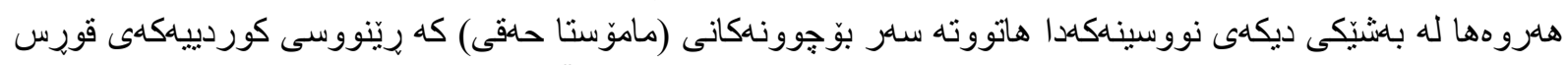

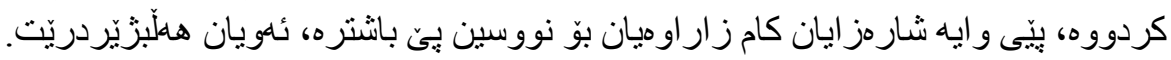

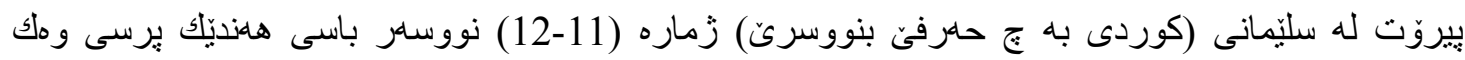

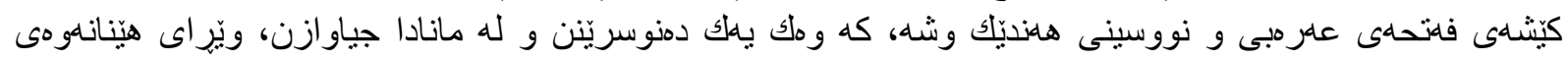

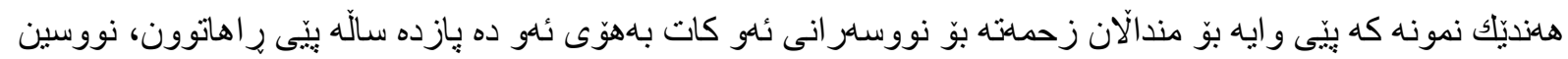

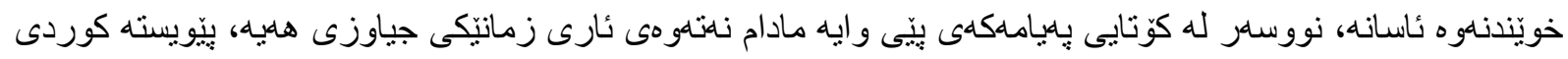

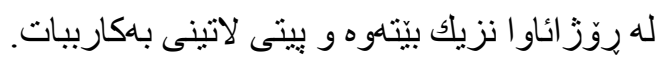

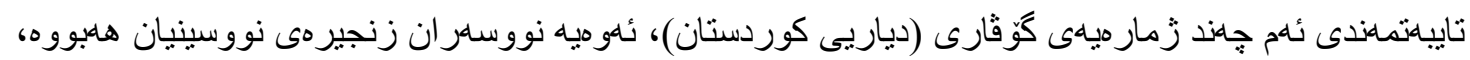

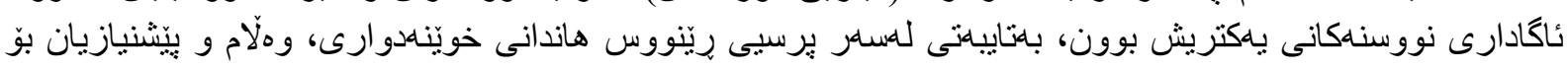

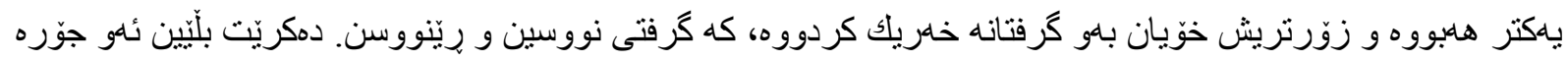

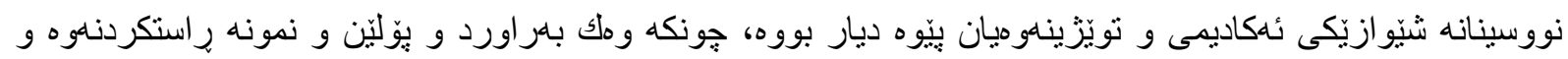

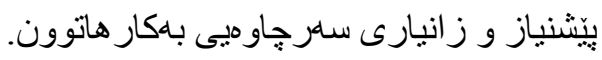

\section{روَّزنامهكَهرى و بِرسى خويَندن.}

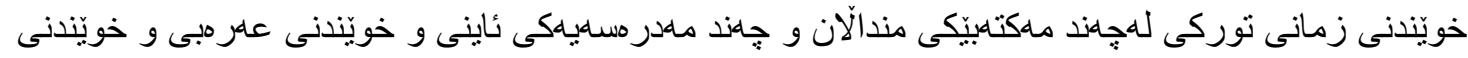

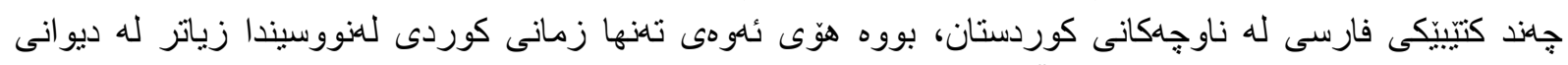

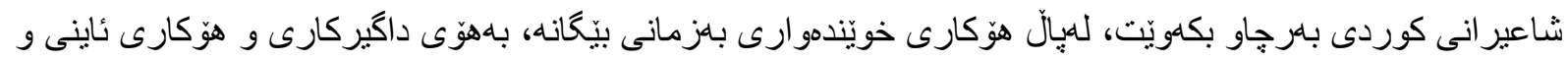

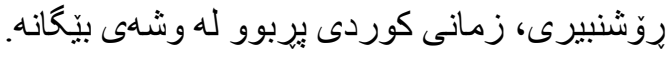

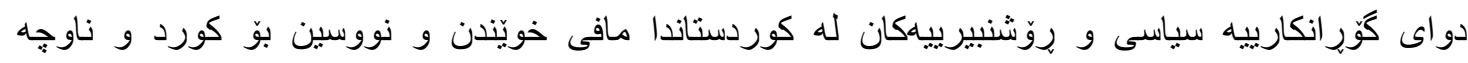

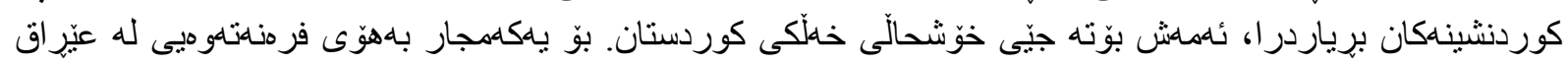

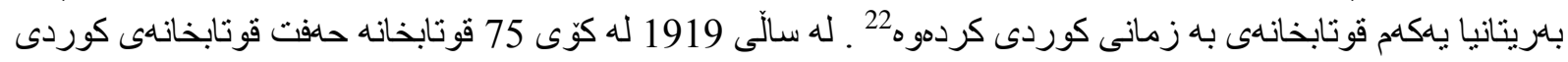

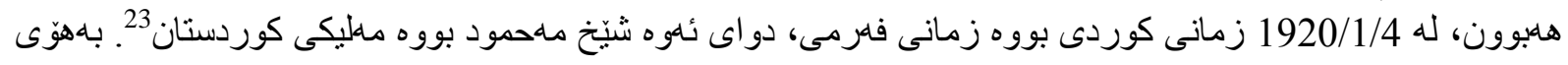

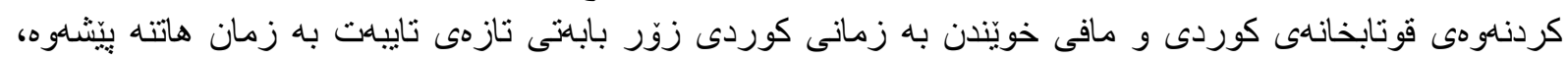

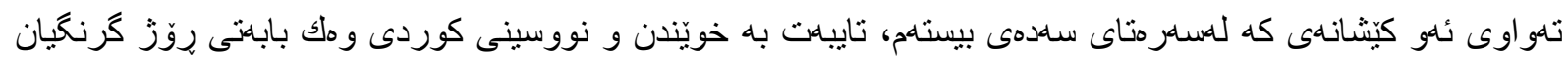

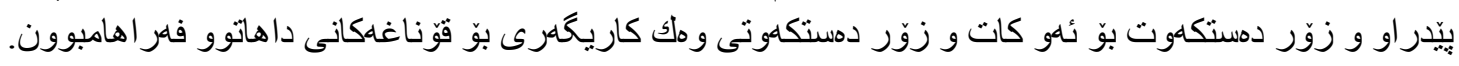

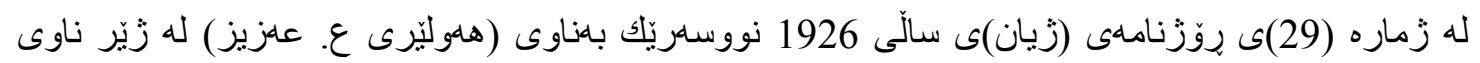

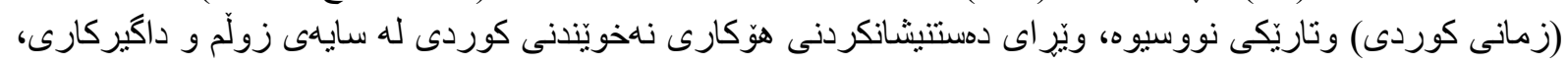

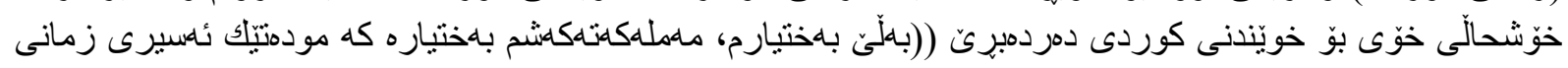

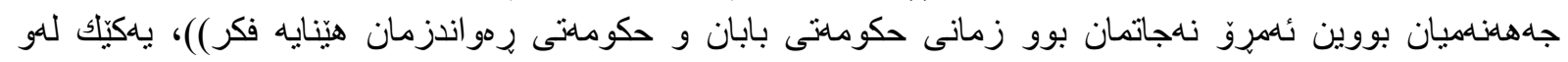




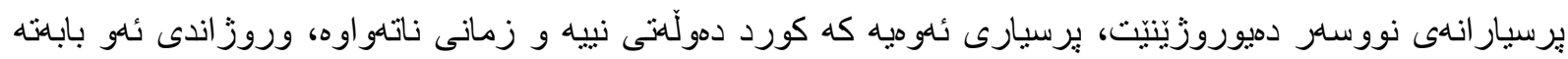

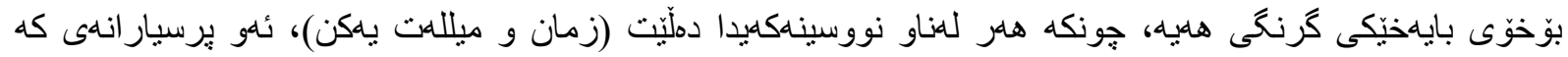

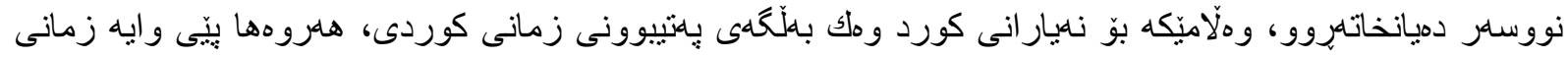

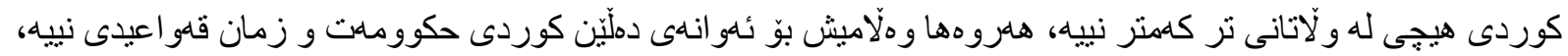

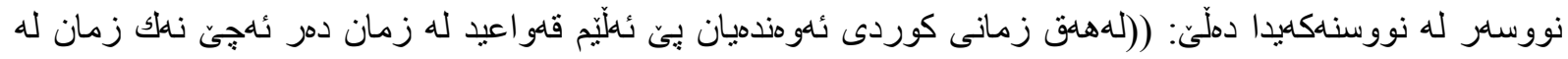

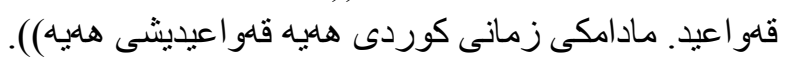

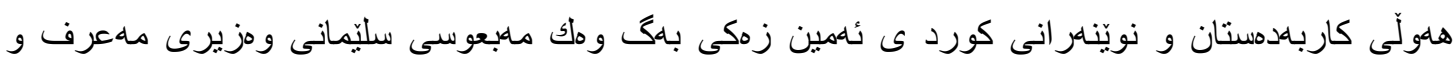

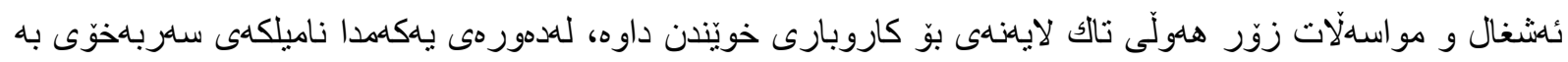

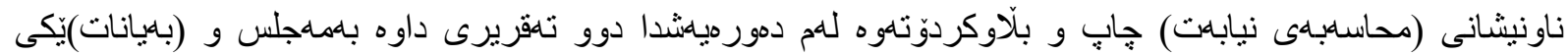

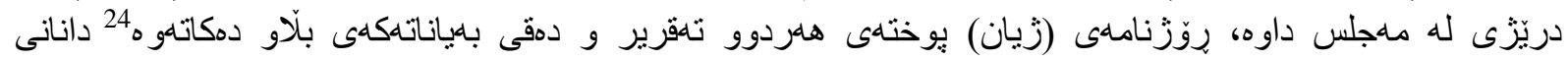

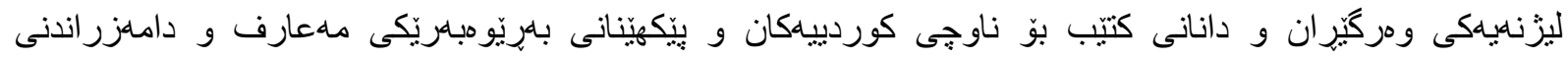

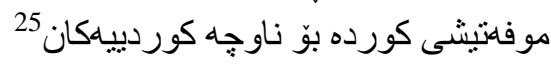

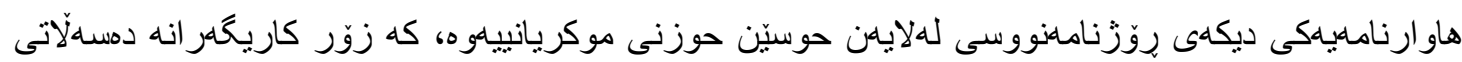

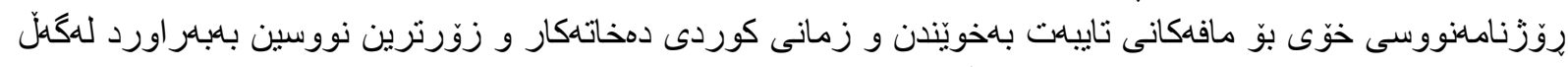

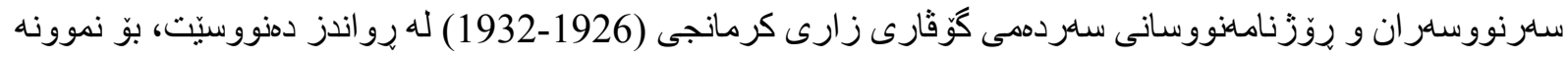

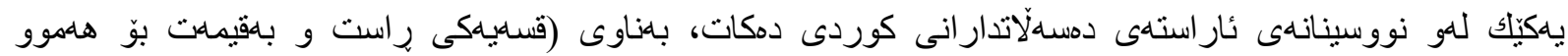

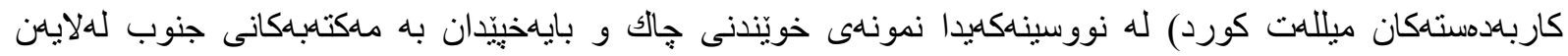

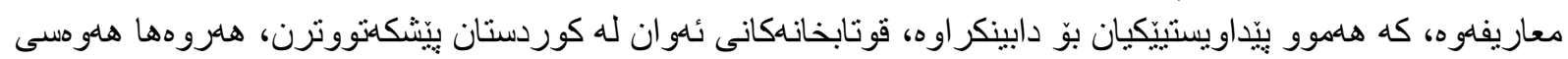

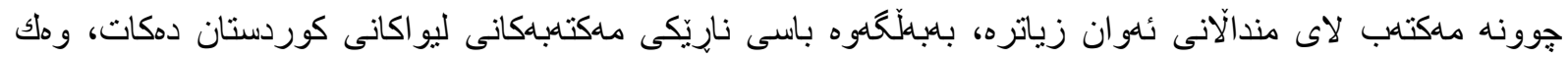

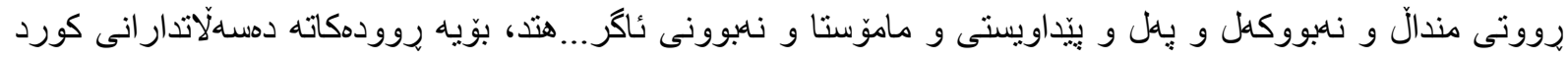

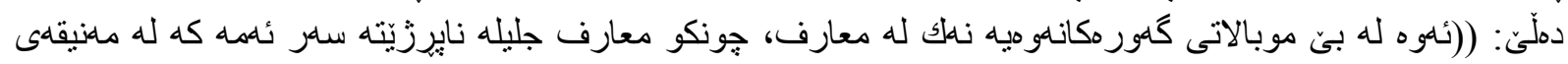

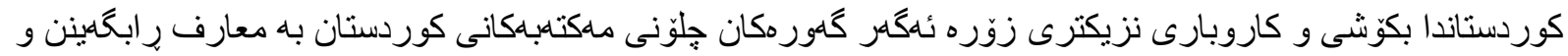

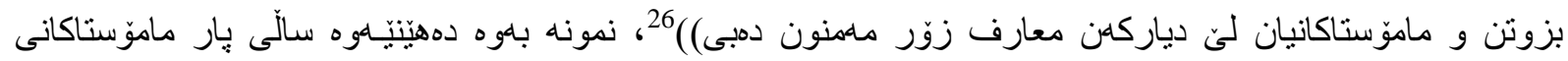

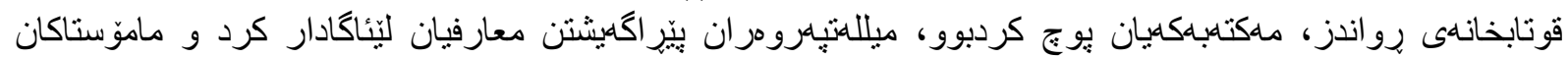

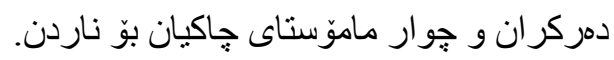

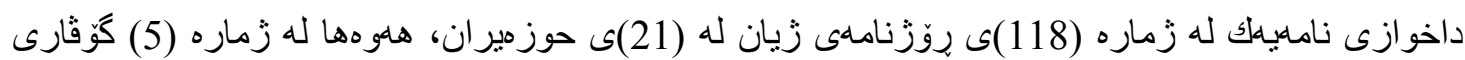

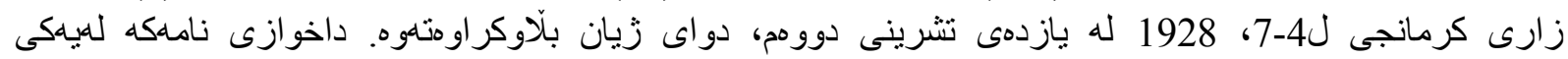

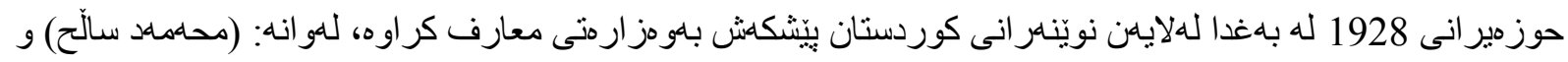

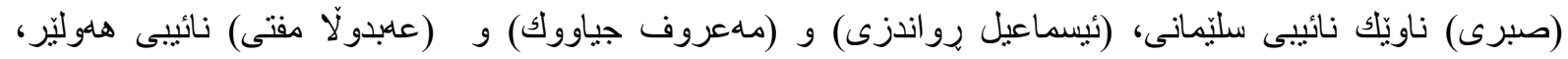

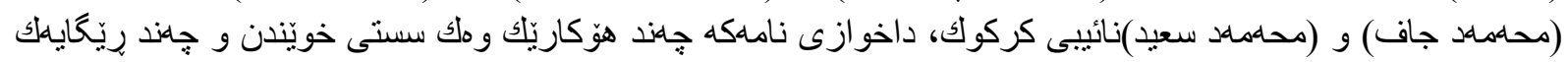

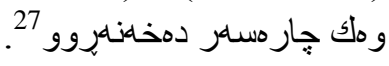

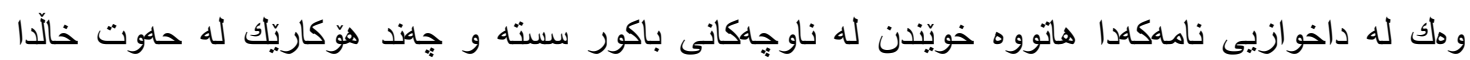

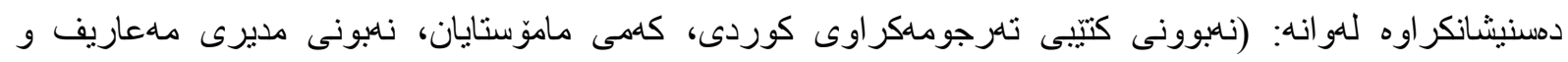

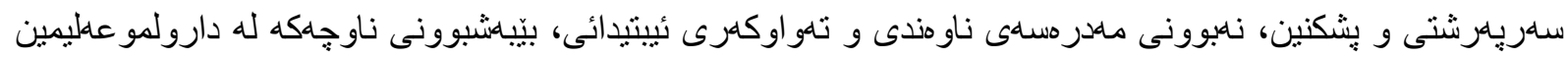

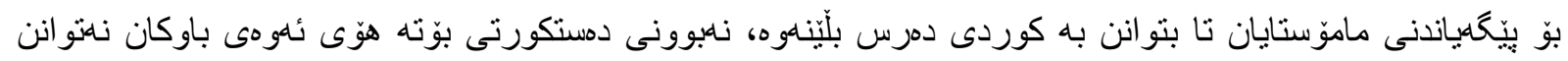

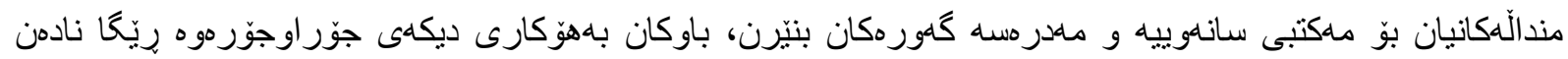

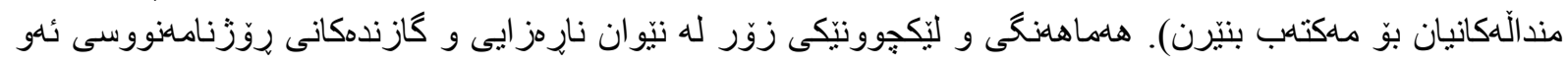

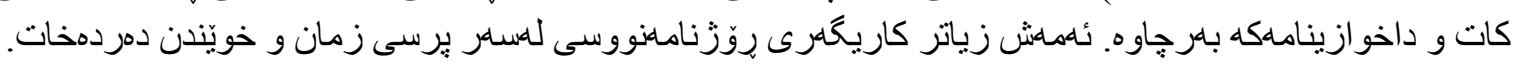

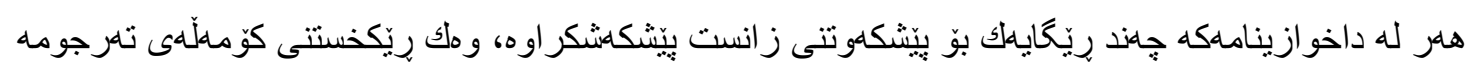

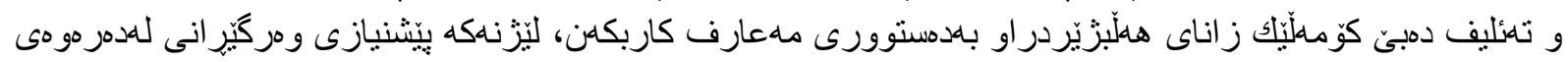




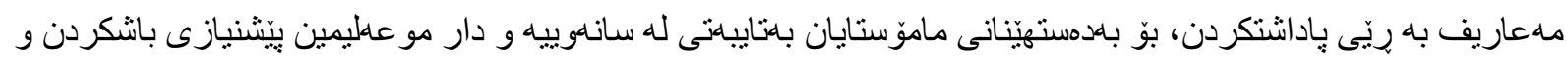

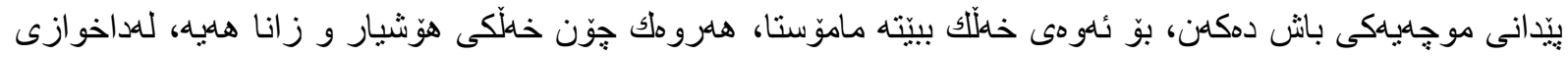

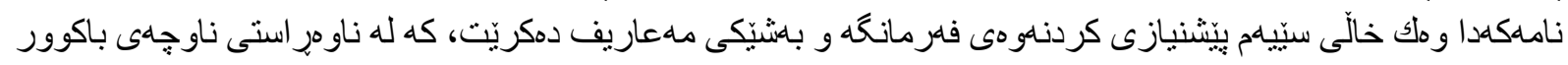

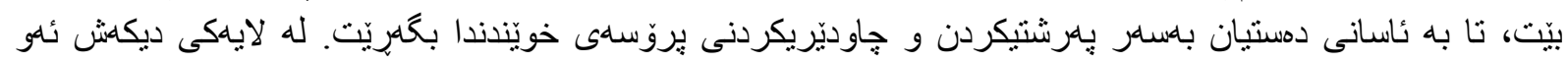

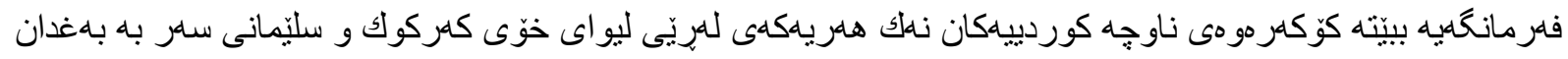

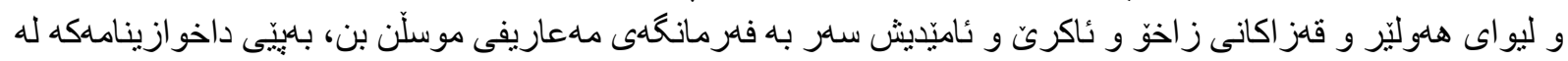

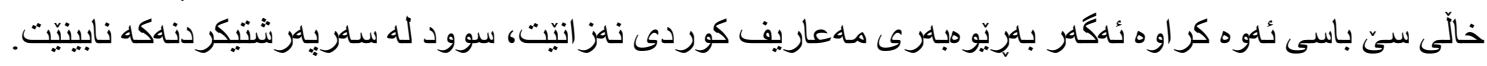

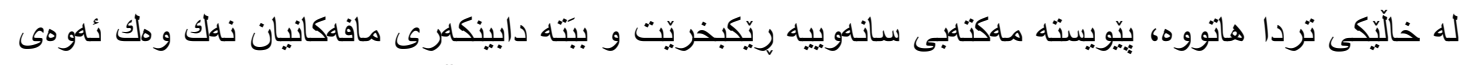

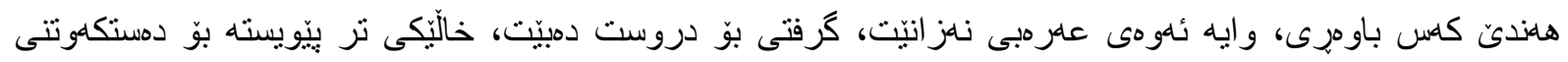

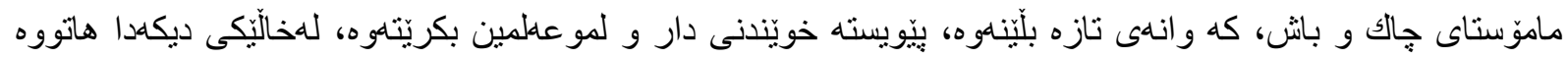

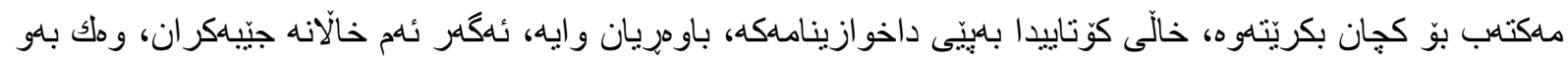

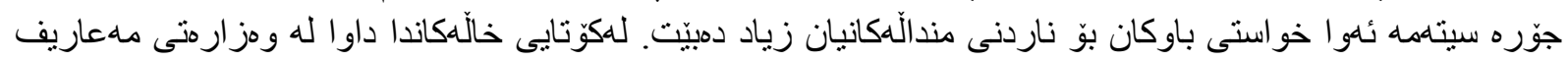

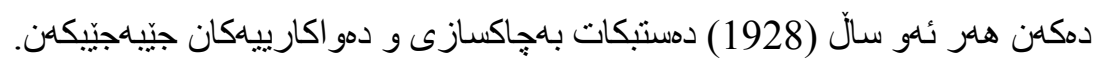

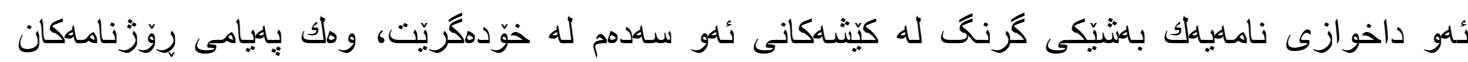

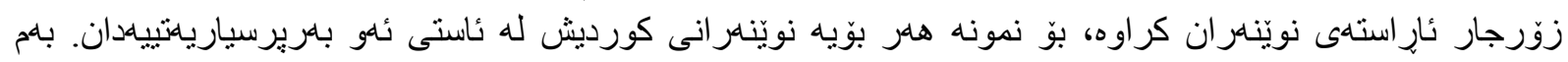

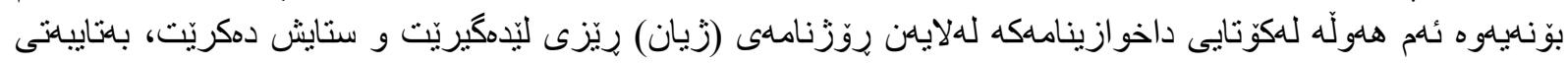

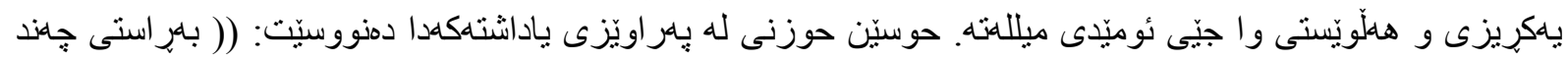

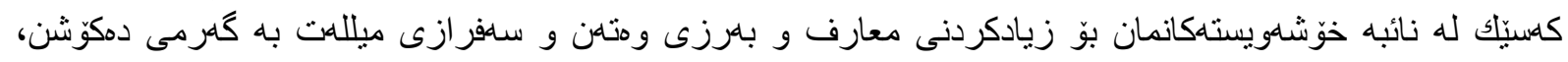

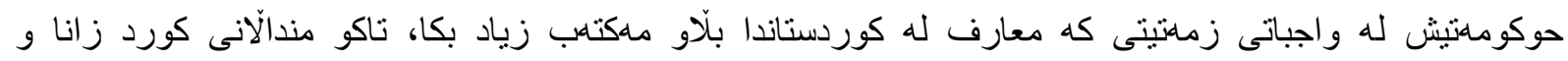

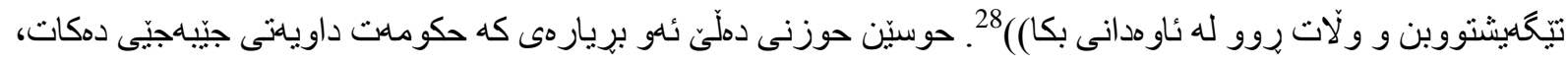

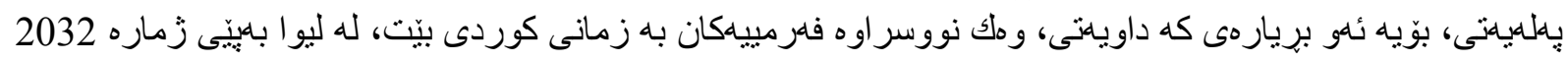

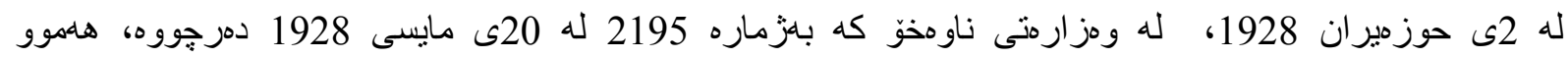

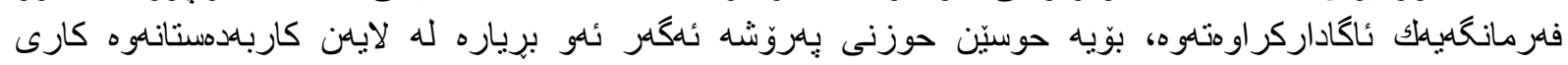

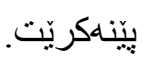

\section{زمان و ناسنامه}

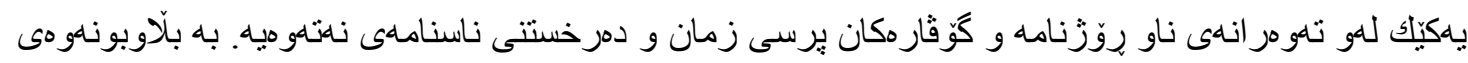

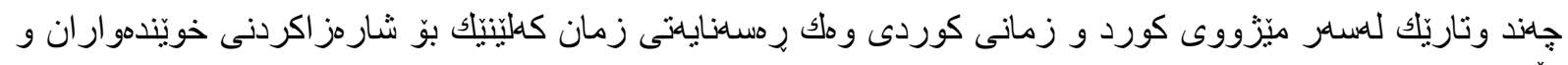

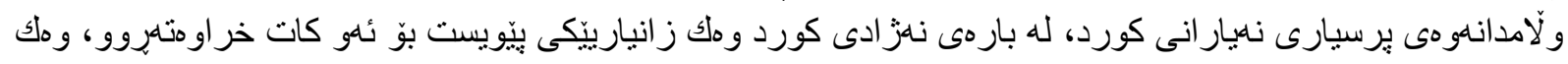

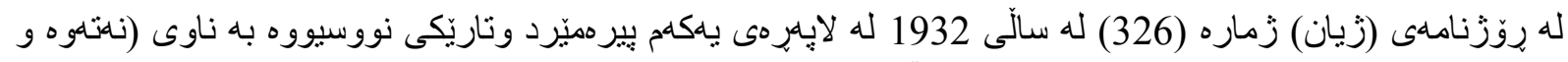

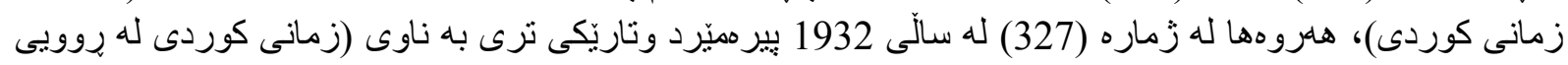

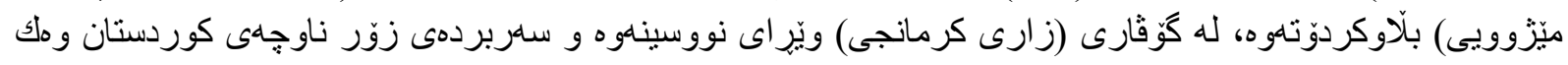

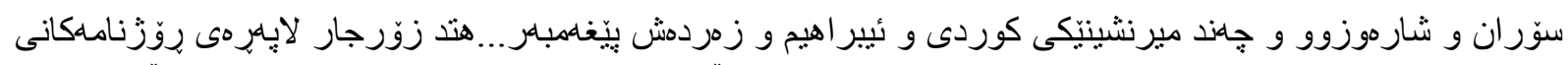

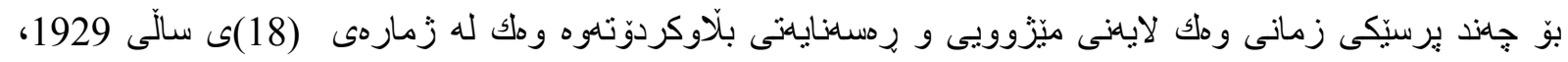

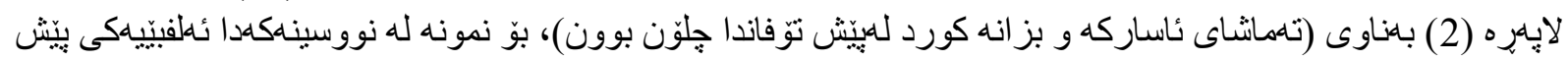

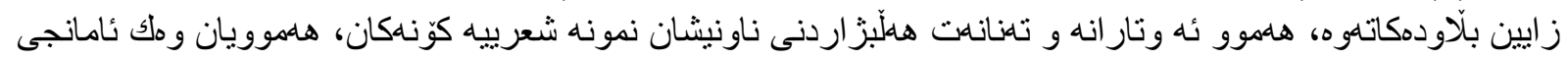

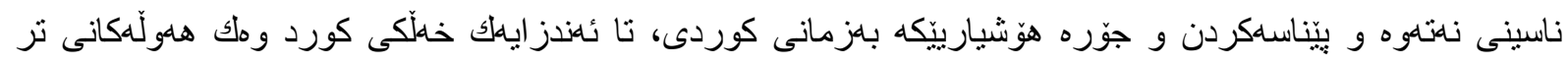

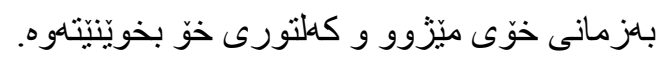

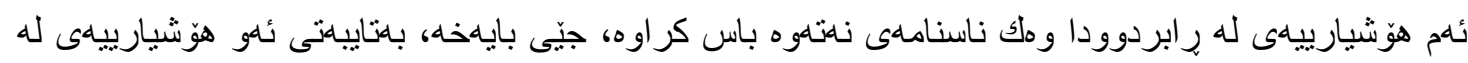

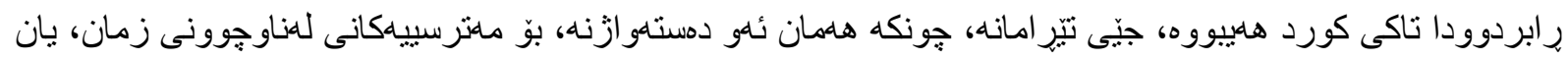

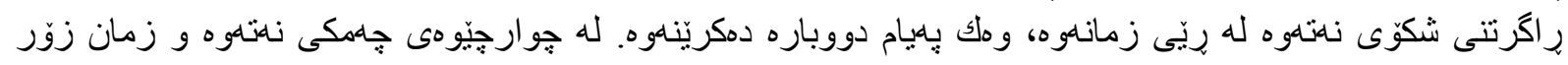




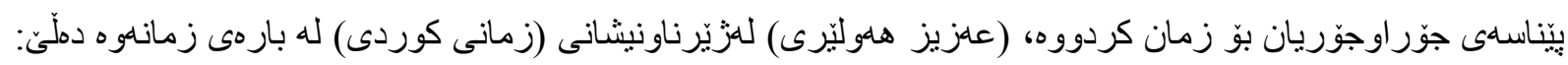

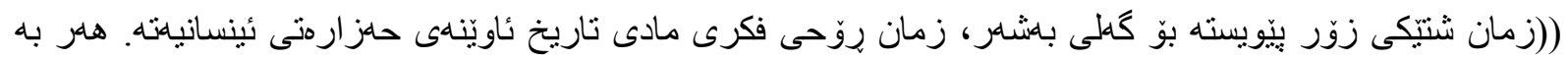

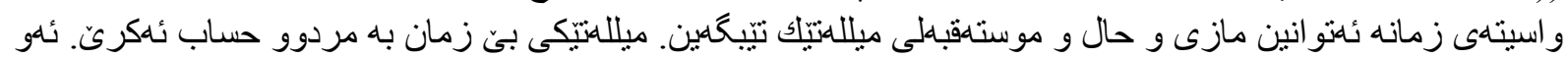

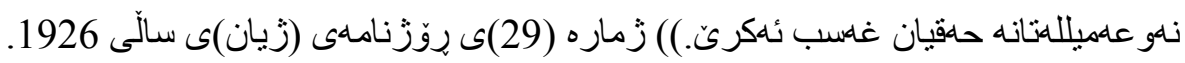

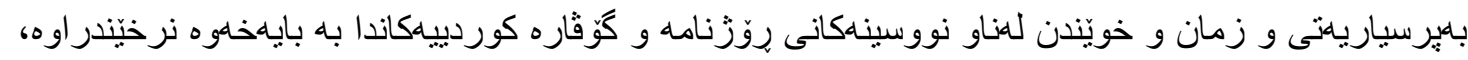

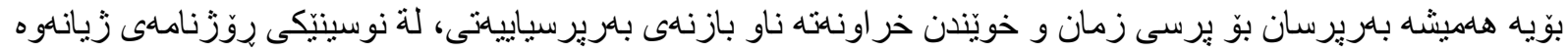

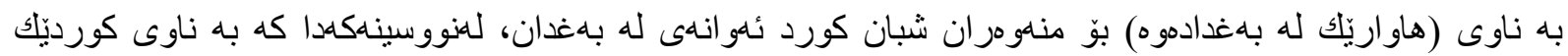

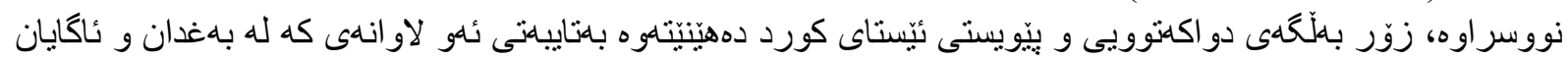

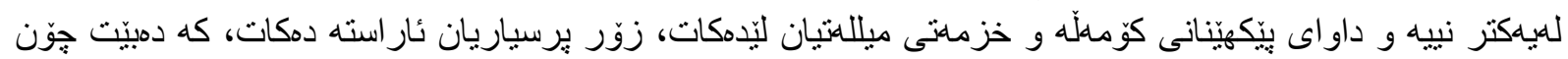

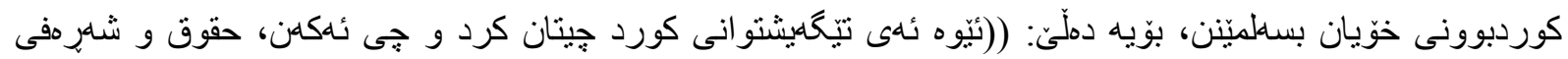

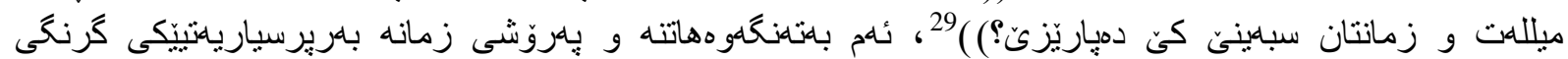

ريوّشنبيرى و سياسيى بووه.

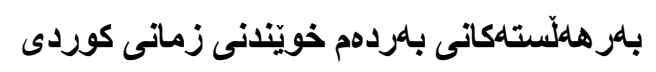

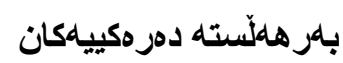

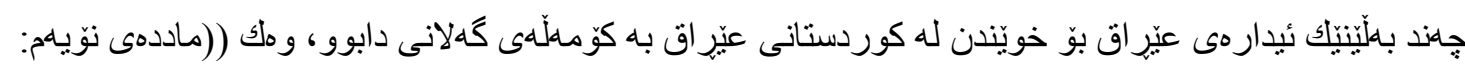

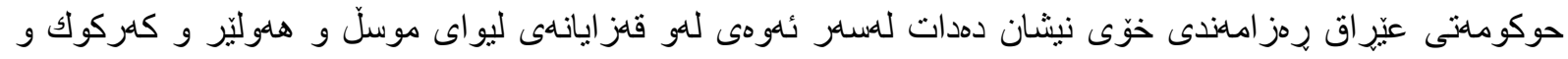

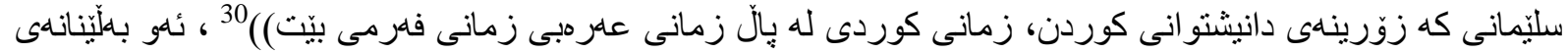

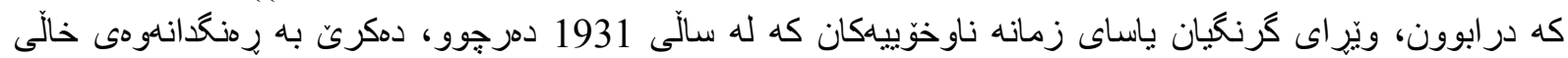

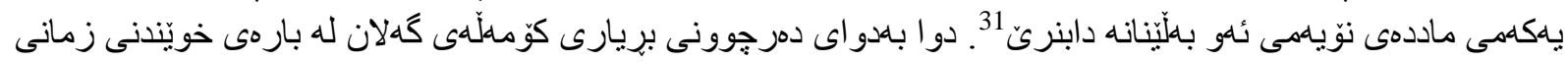

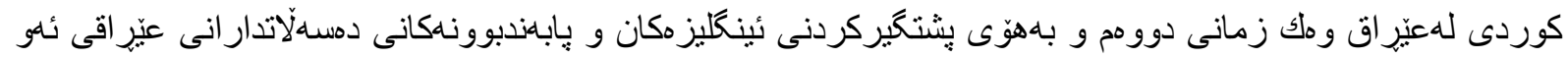

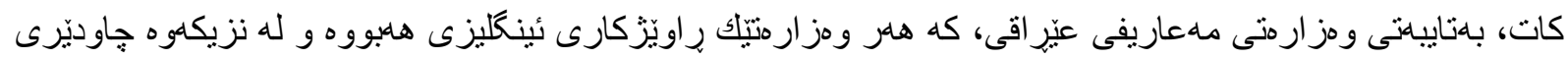

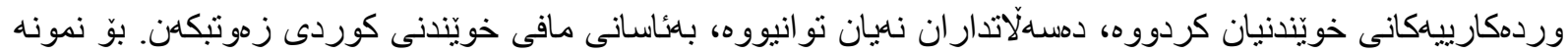

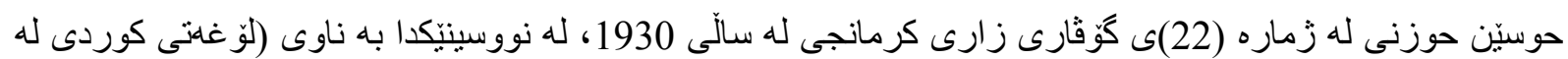

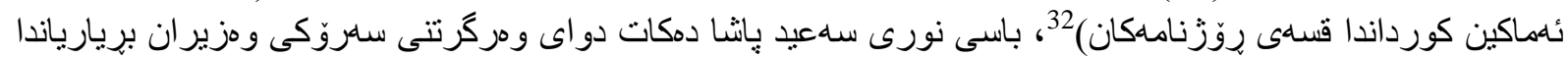

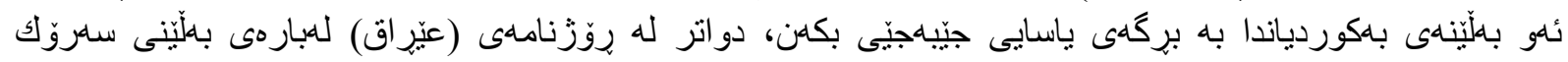

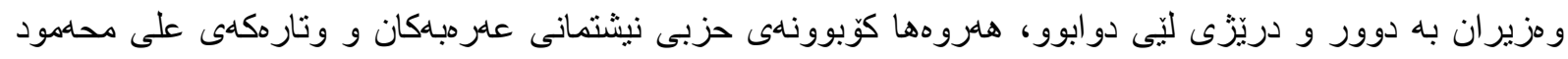

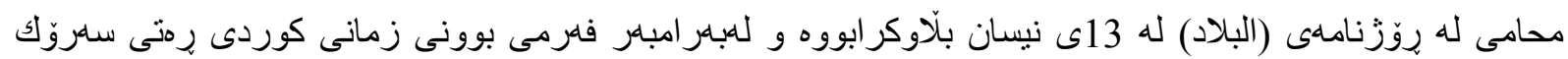

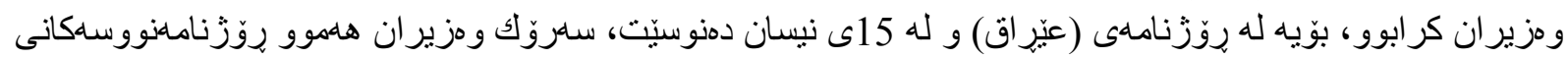

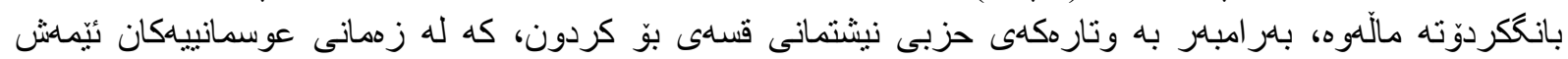

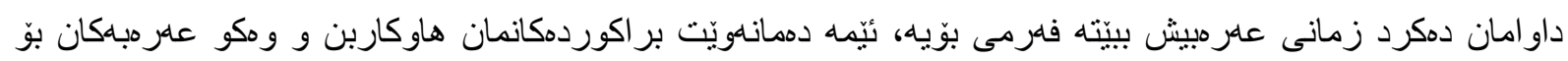

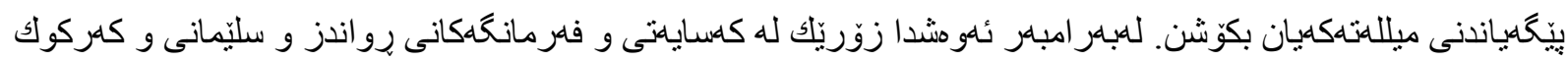

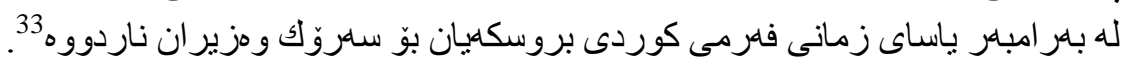

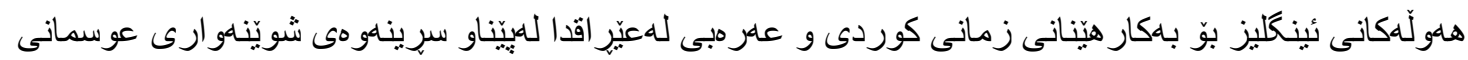

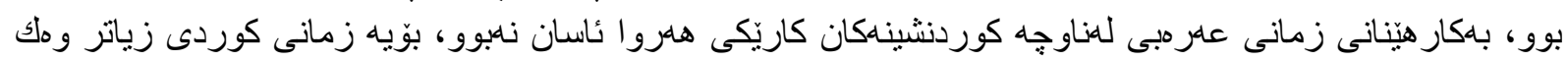

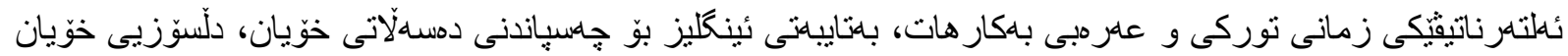

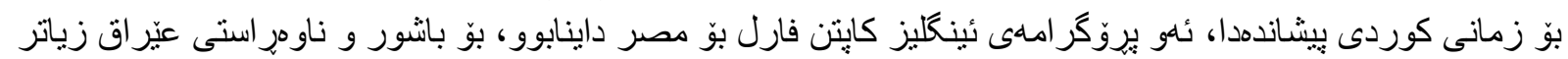

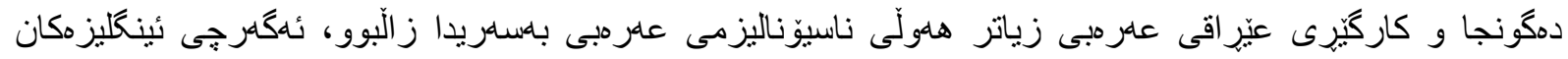

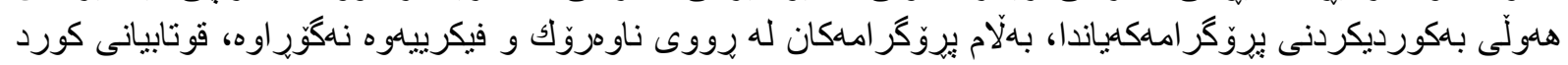

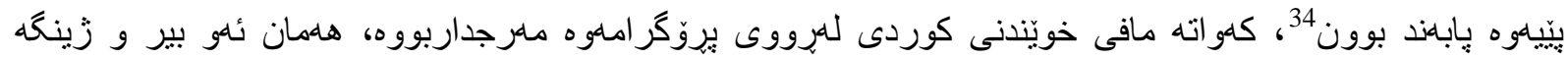

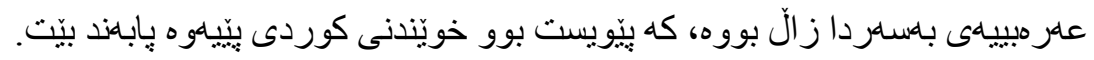




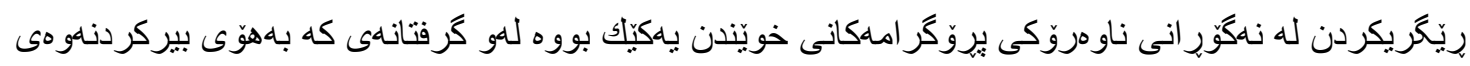

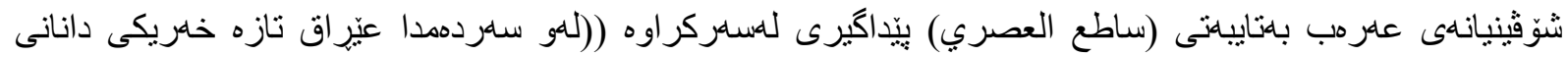

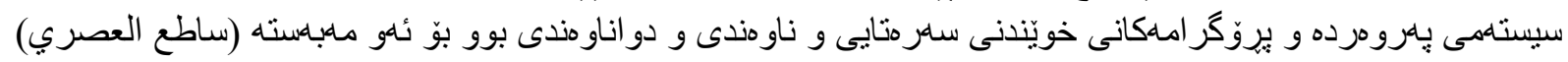

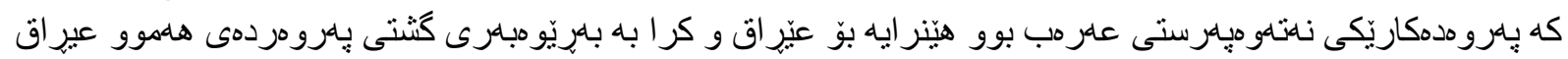

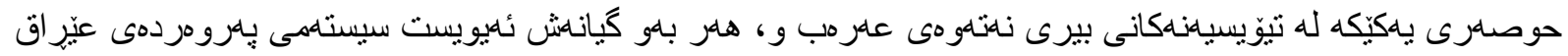

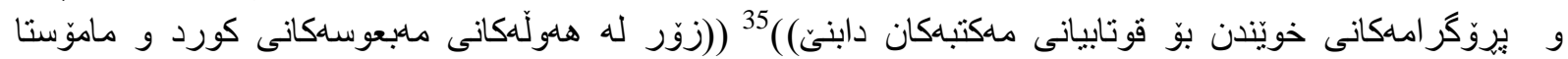

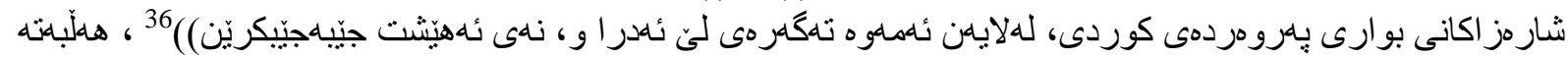

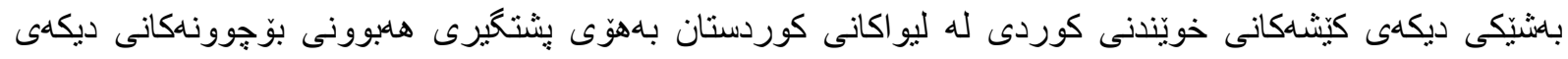

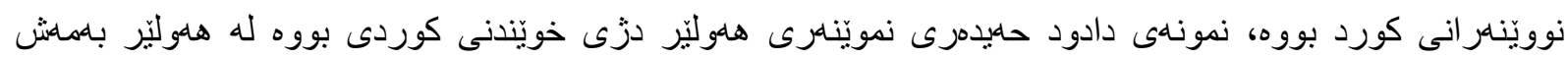

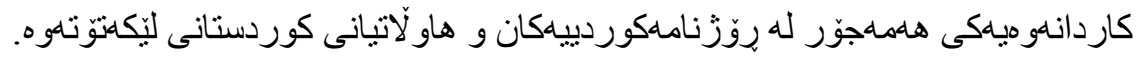

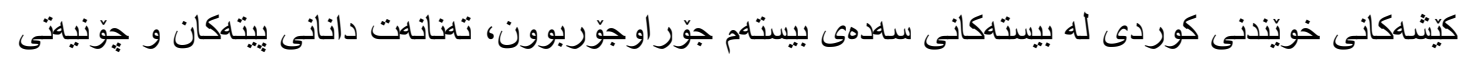

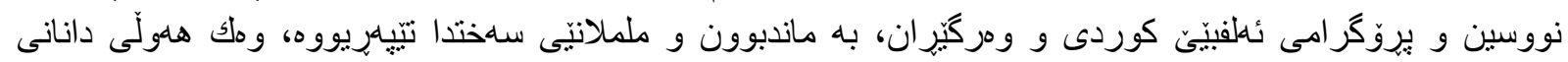

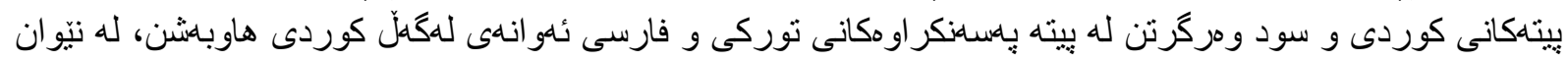

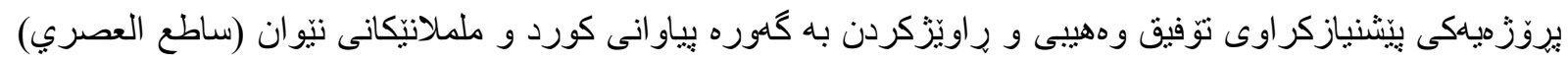

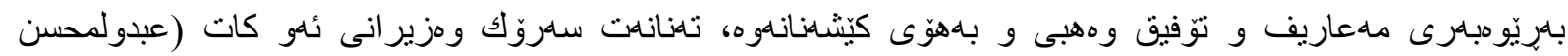

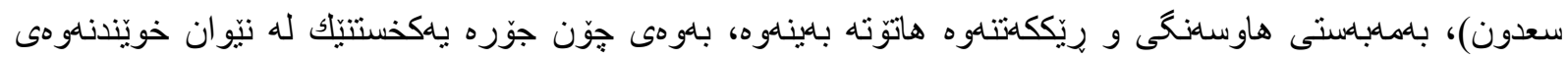

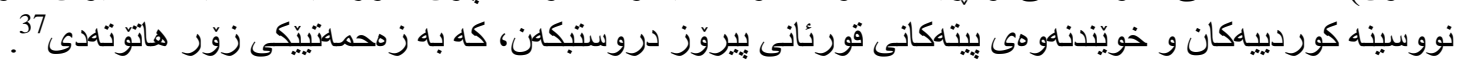

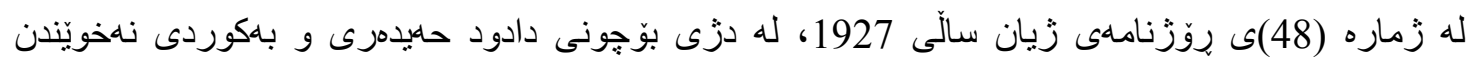

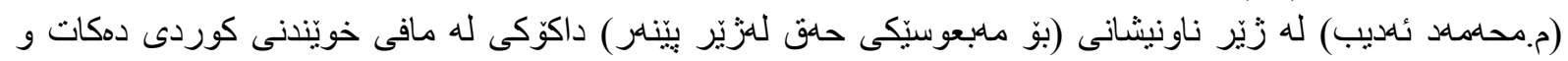

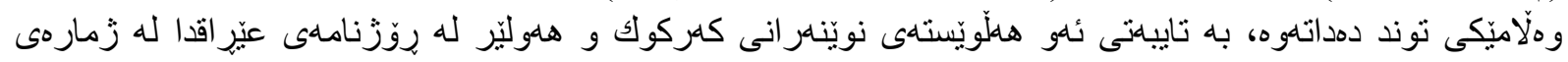

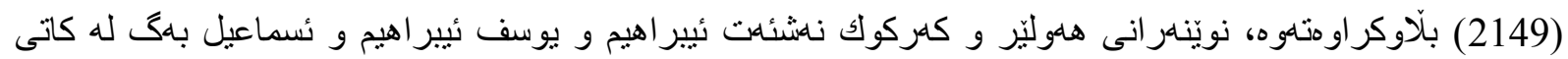

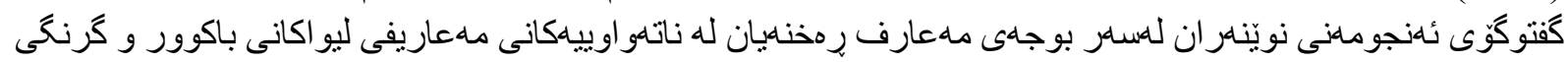

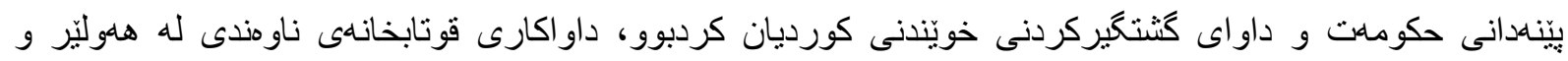

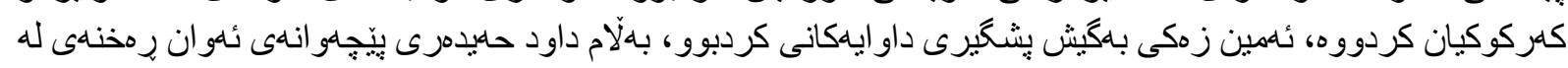

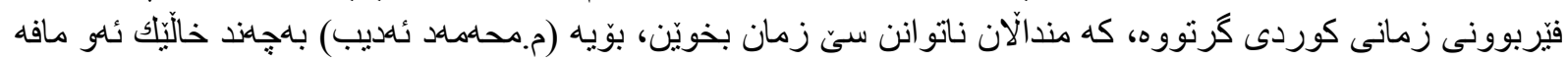

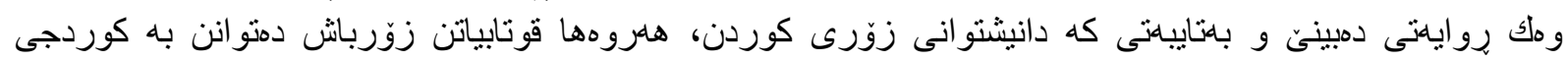

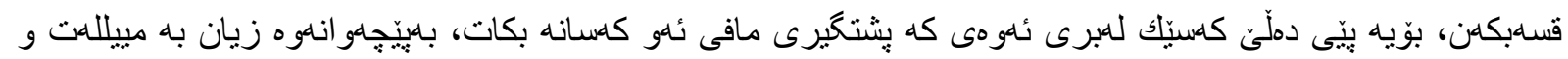

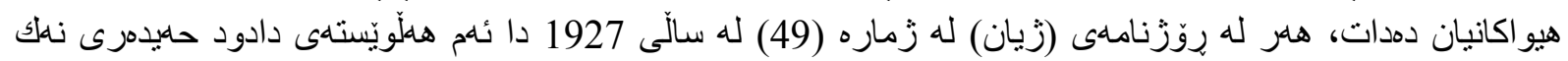

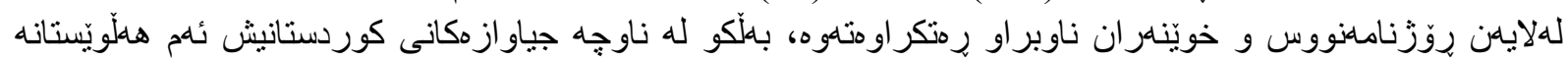

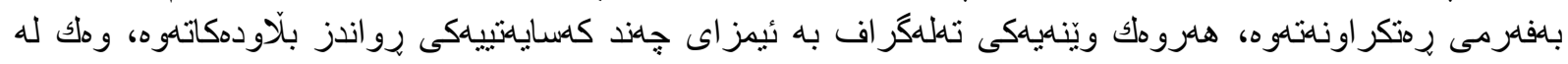

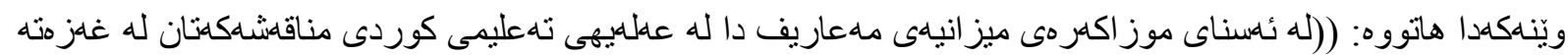

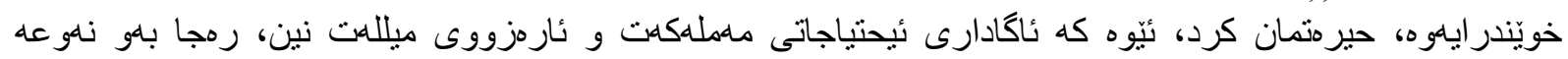

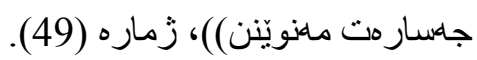

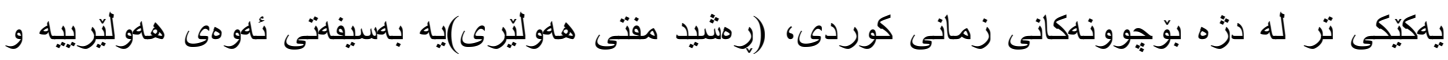

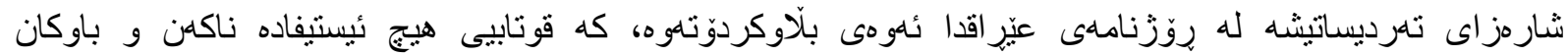

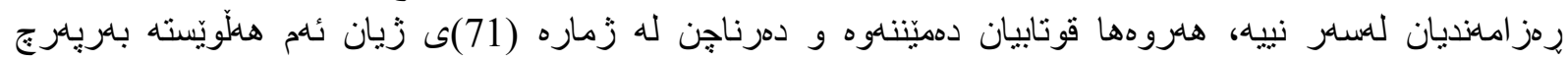

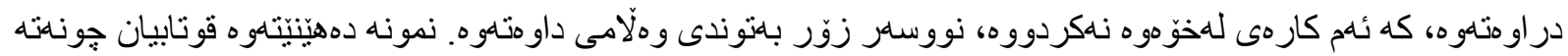

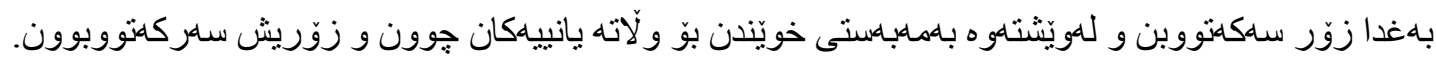

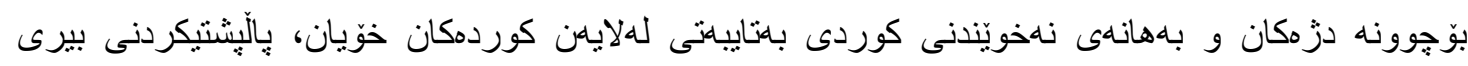

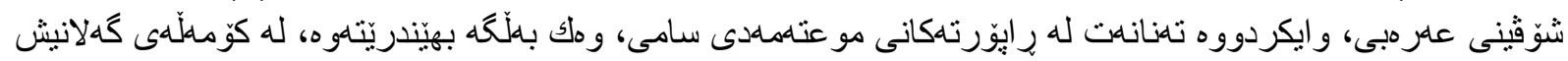

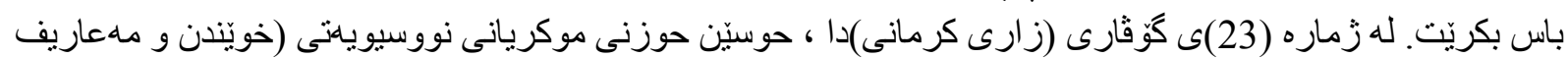




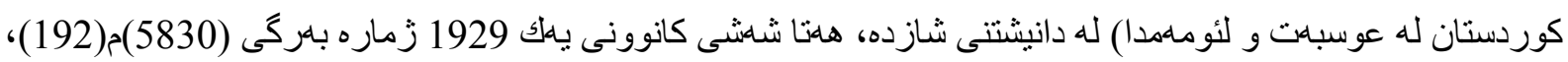

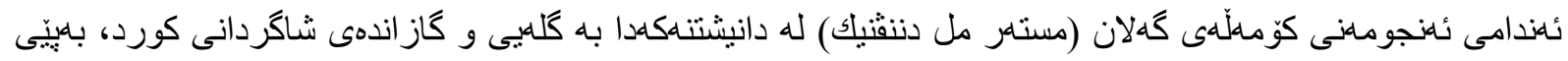

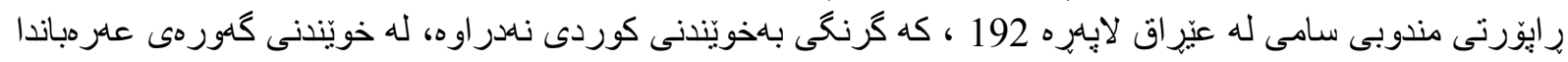

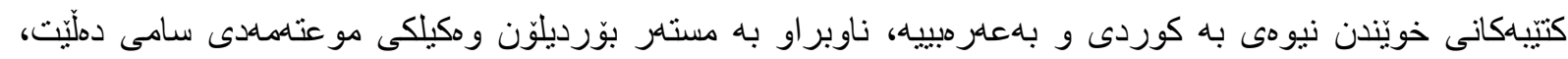

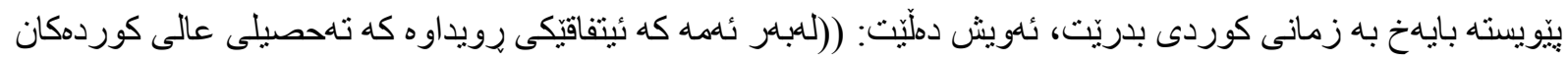

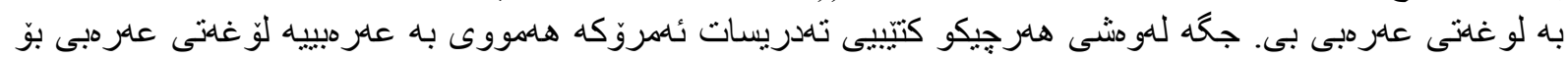

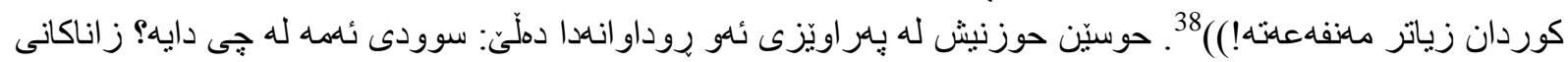

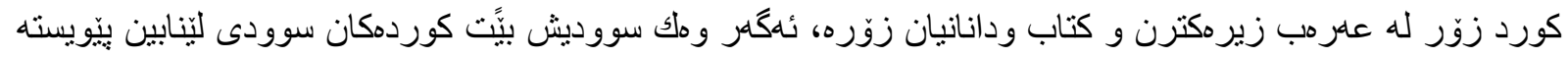

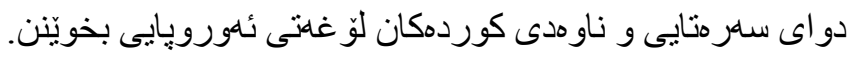

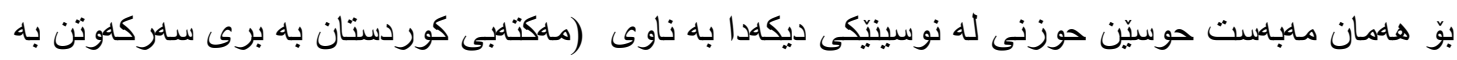

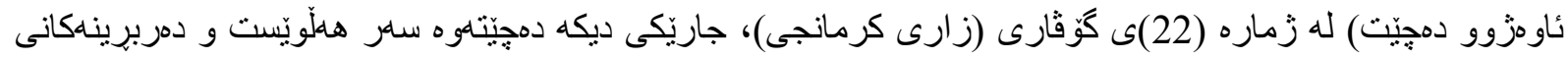

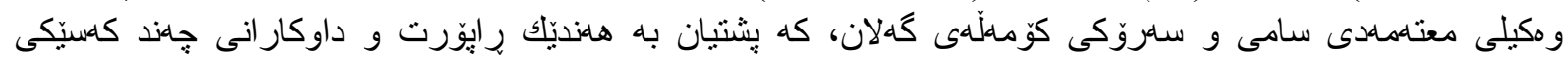

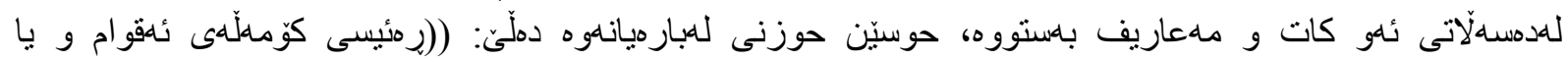

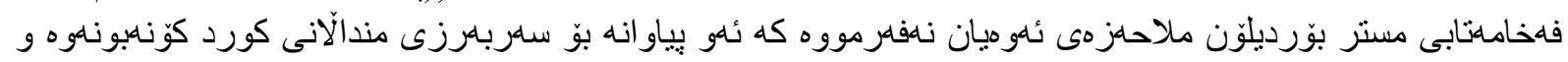

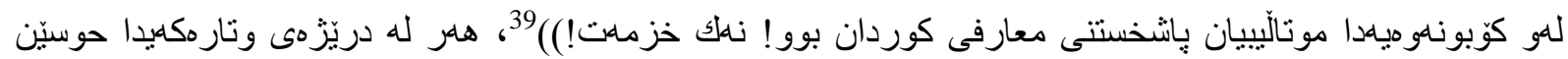

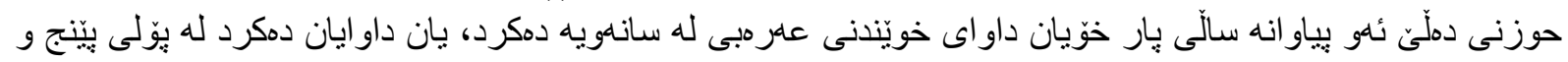

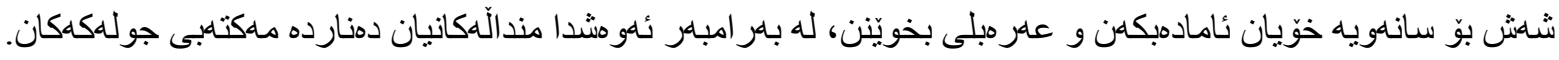

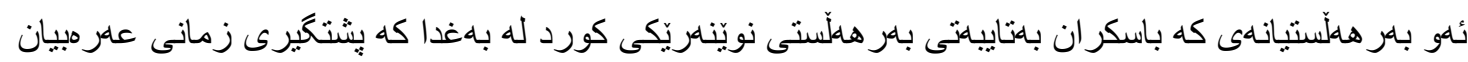

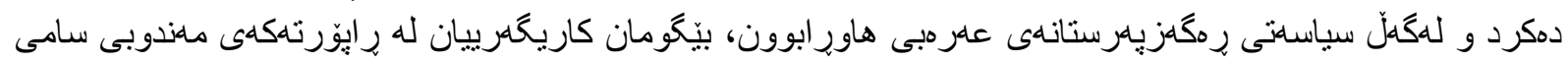

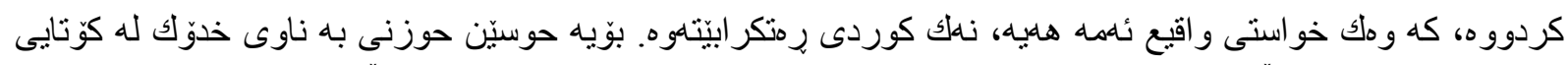

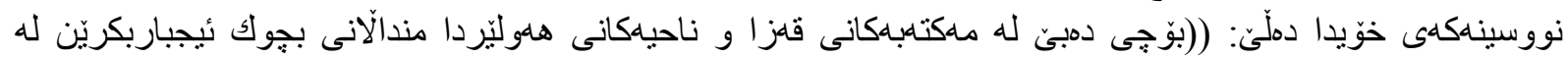

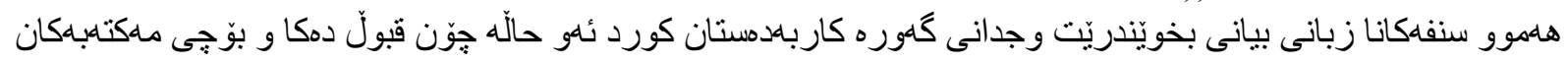

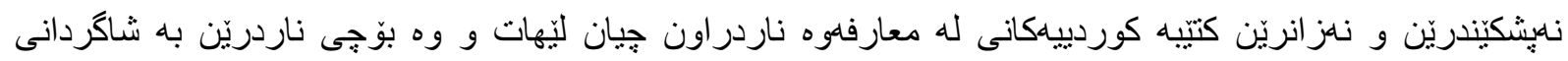

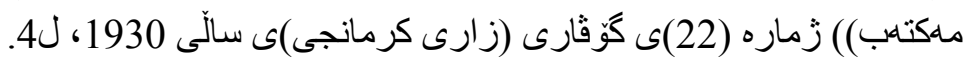

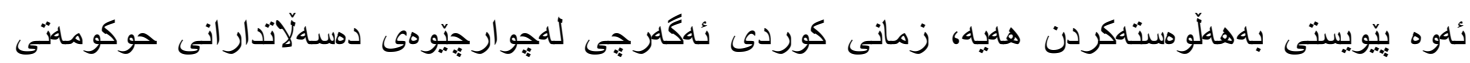

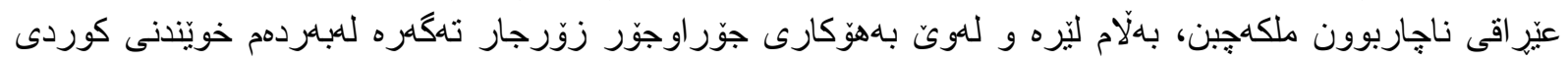

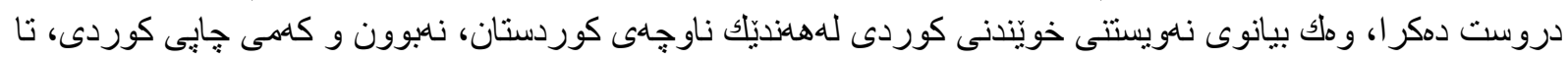

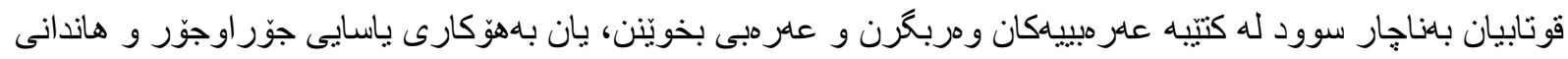

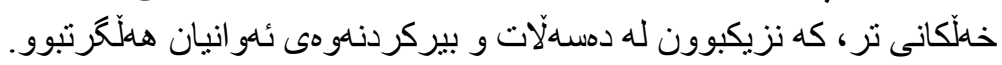

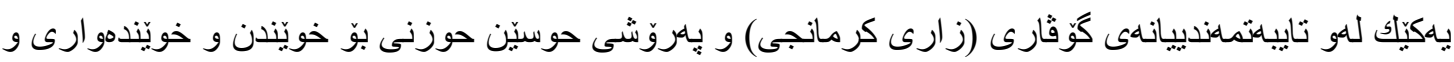

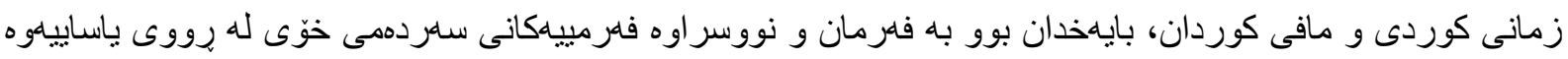

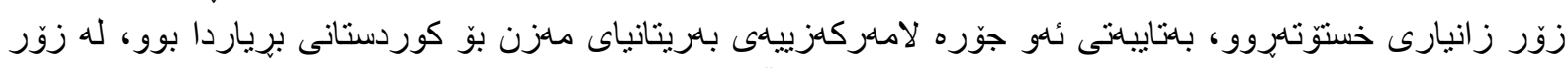

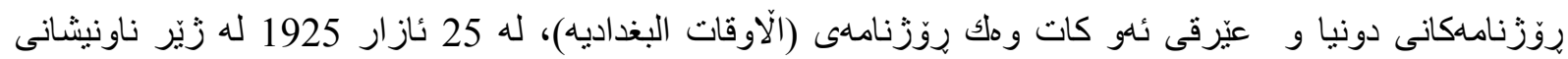

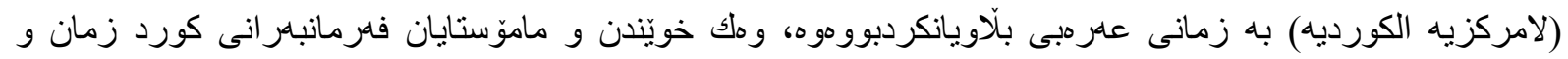

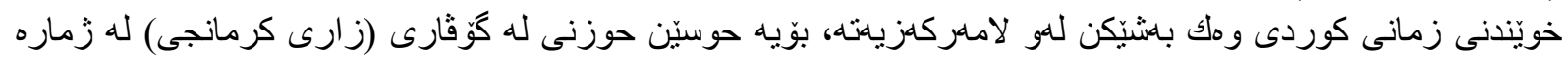

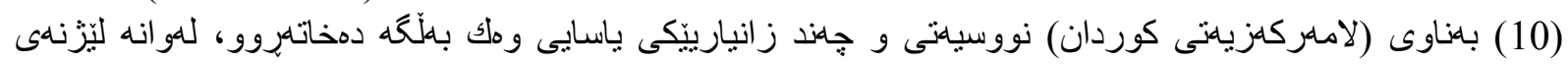

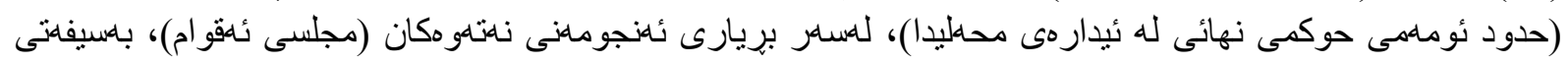

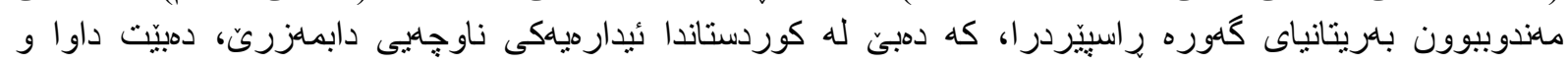

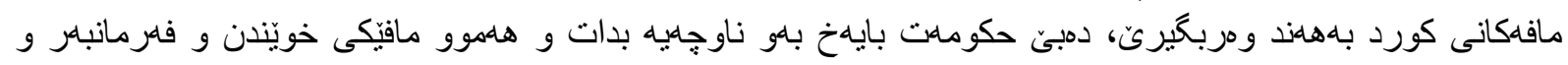

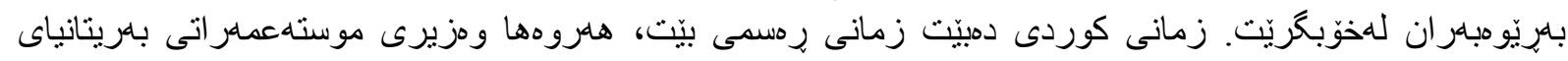

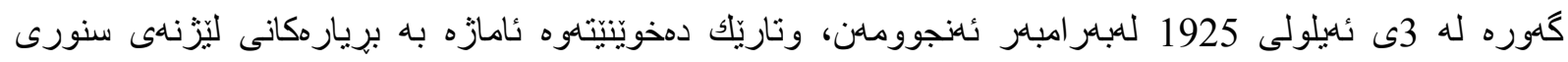




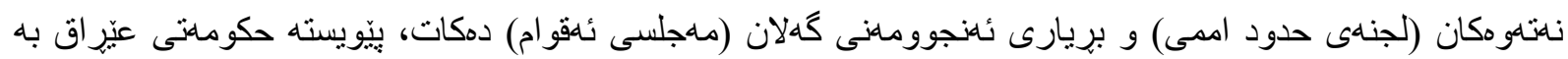

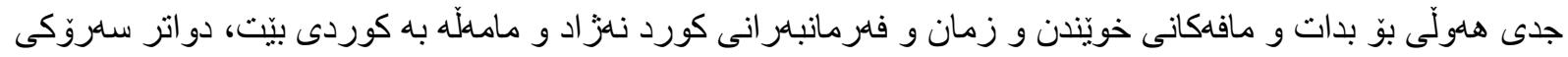

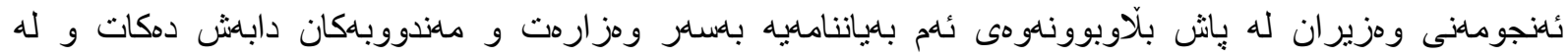

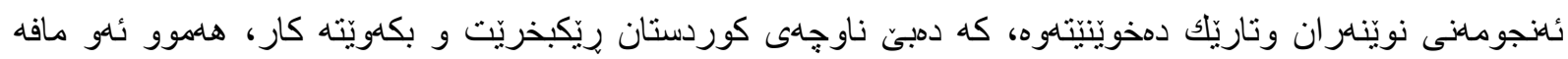

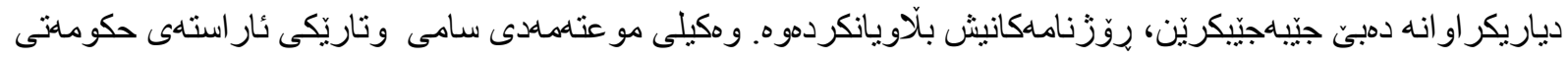

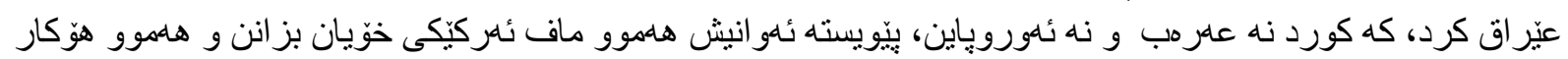

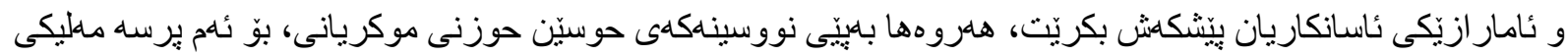

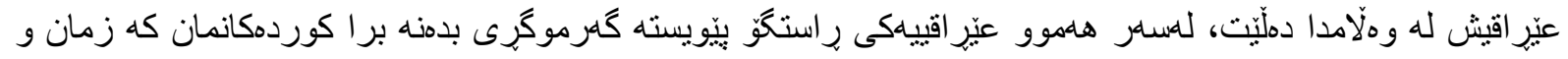

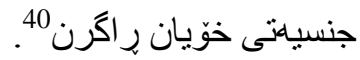

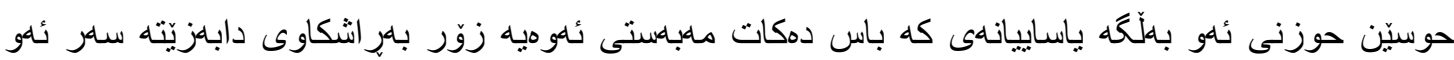

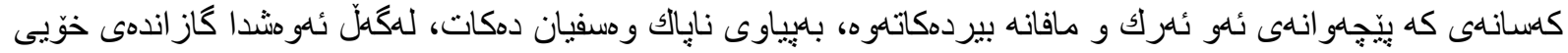

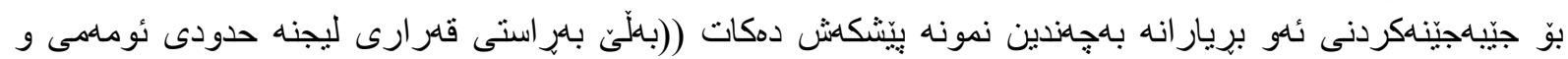

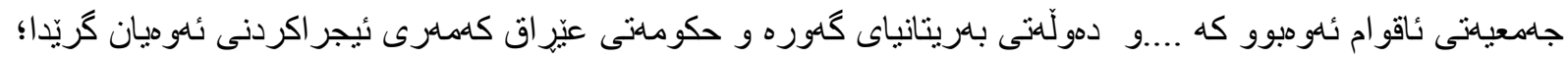

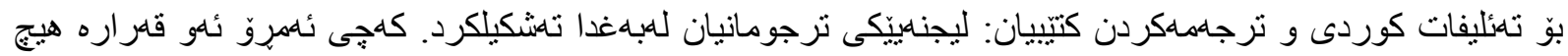

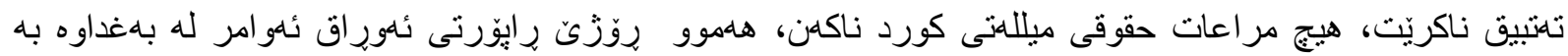

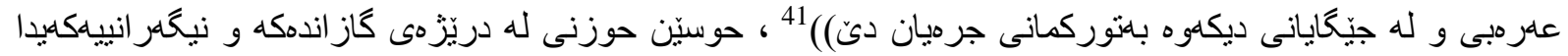

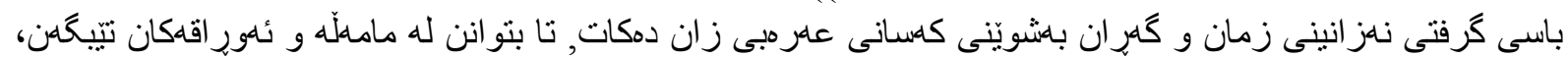

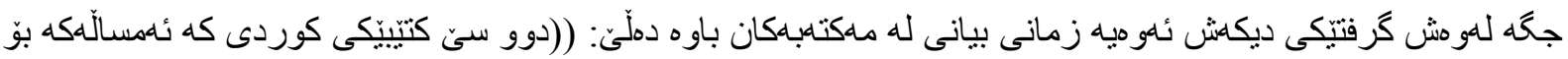

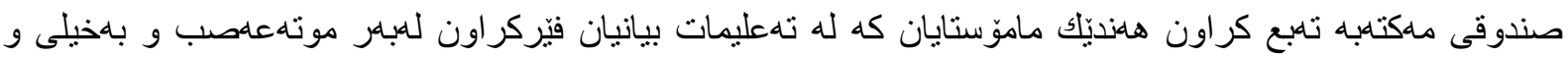

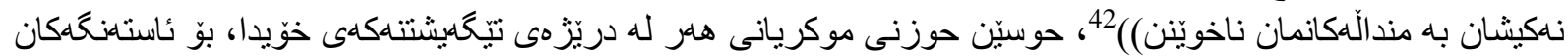

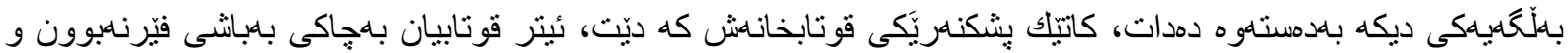

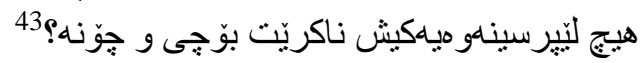

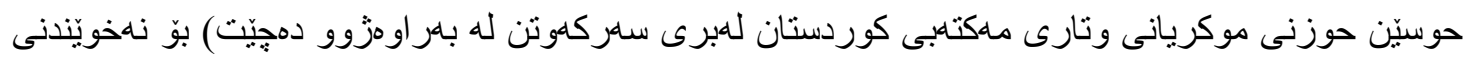

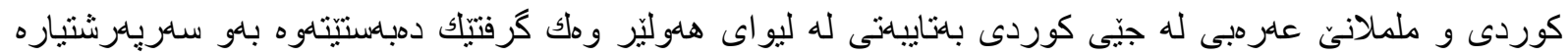

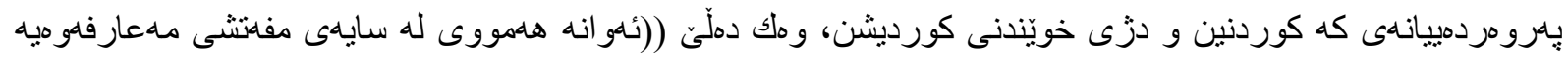

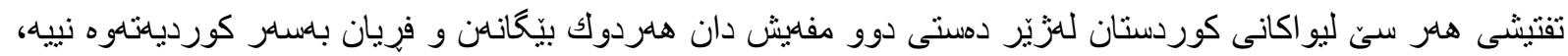

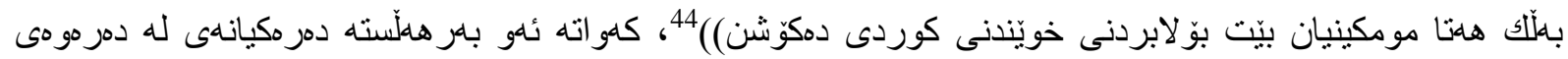

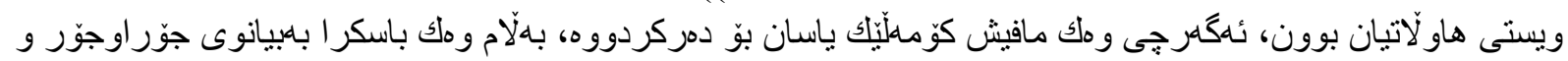

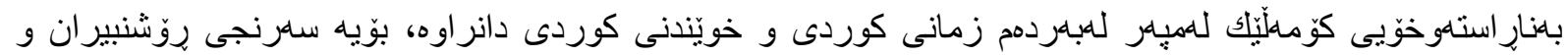

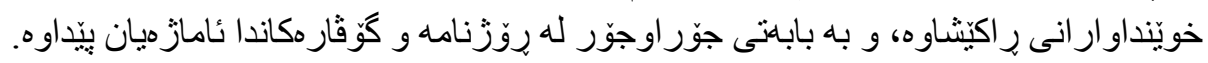

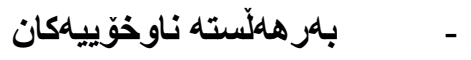

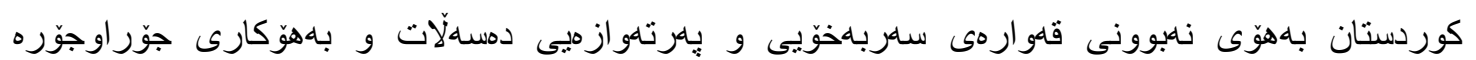

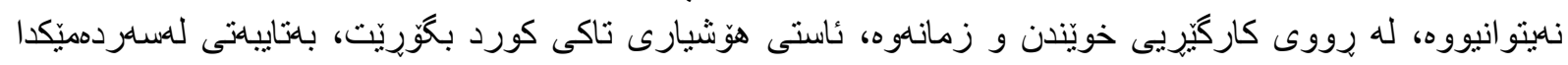

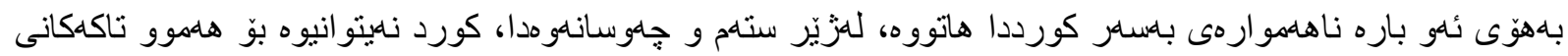

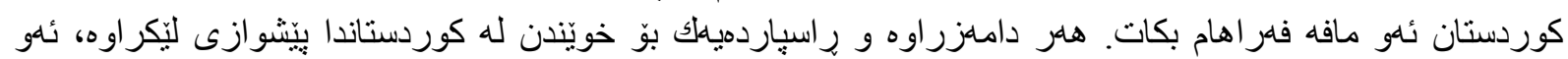

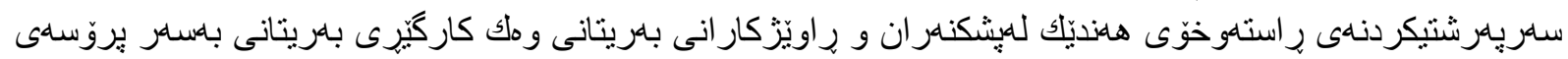

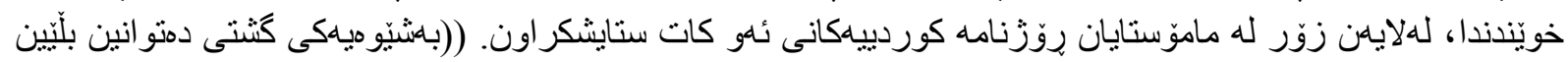

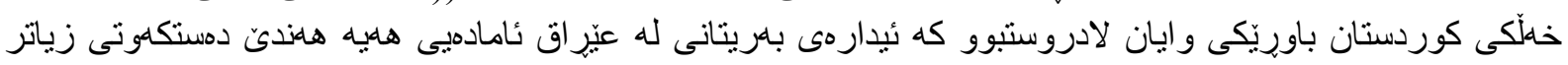

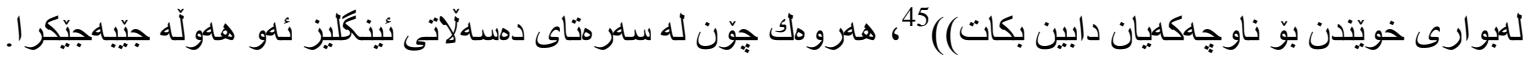




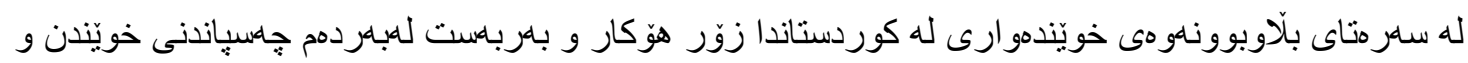

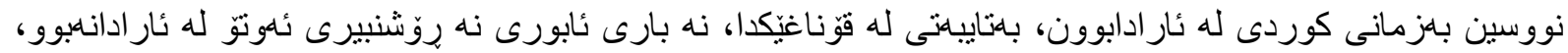

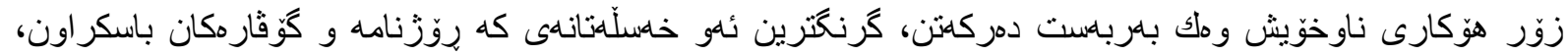

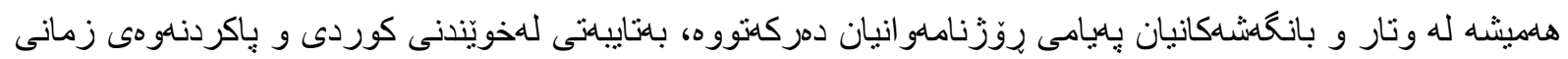

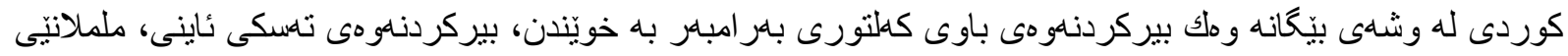

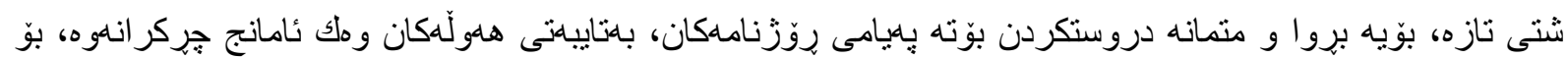

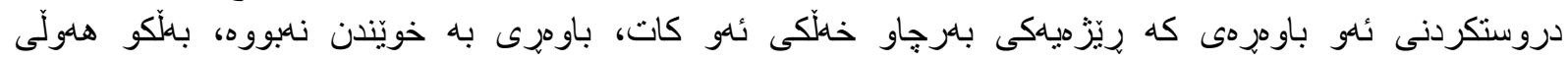

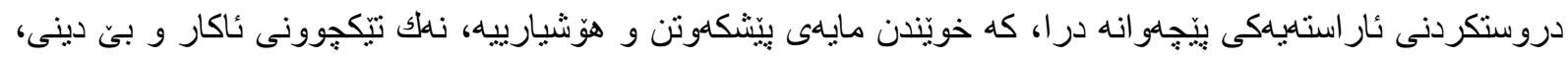

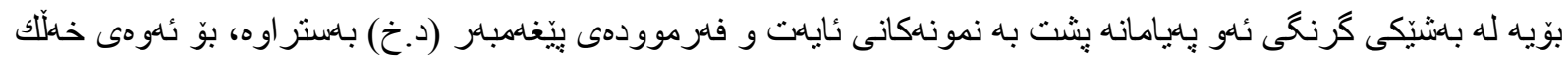

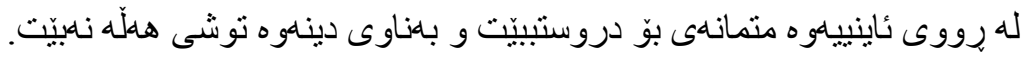

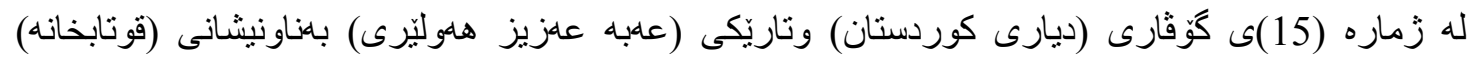

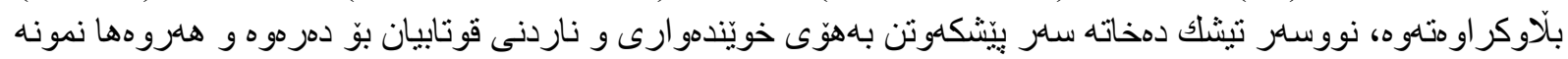

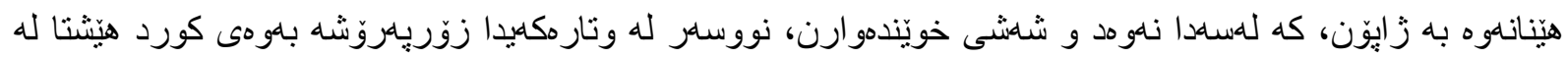

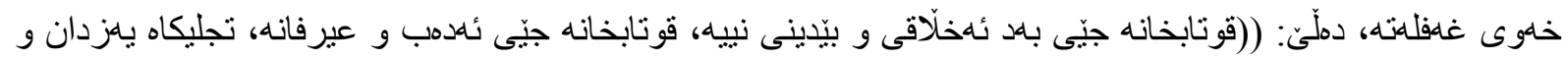

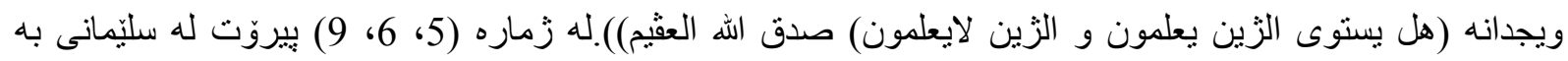

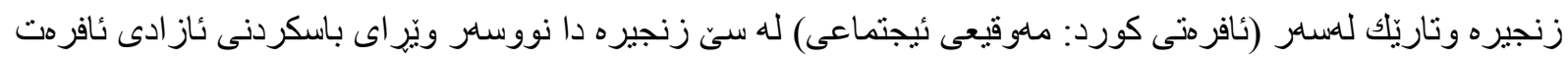

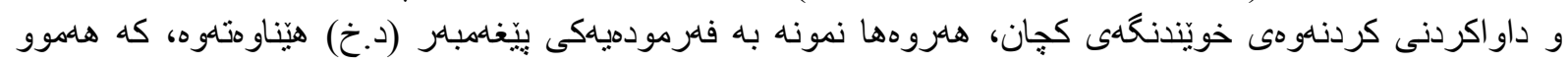

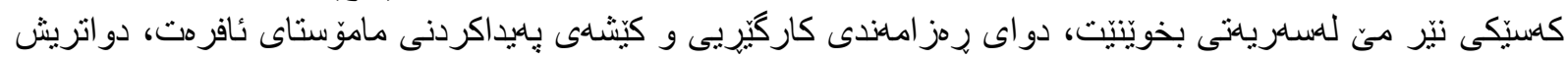

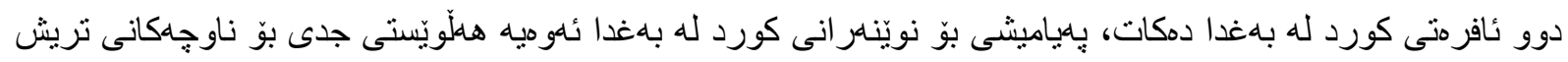

بنويَنن.

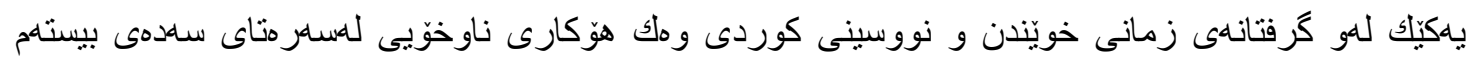

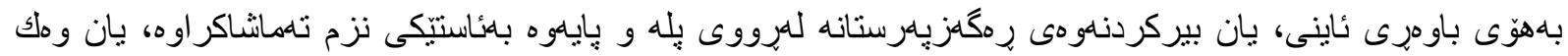

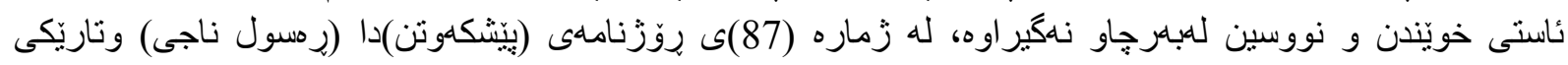

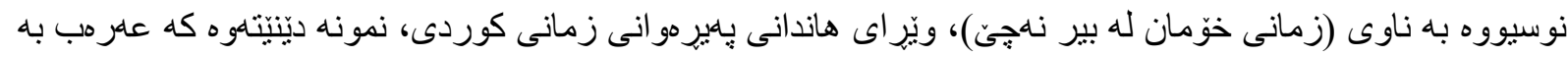

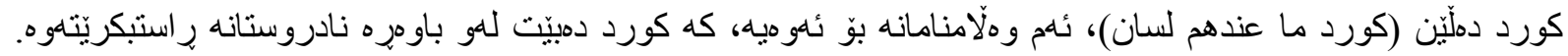

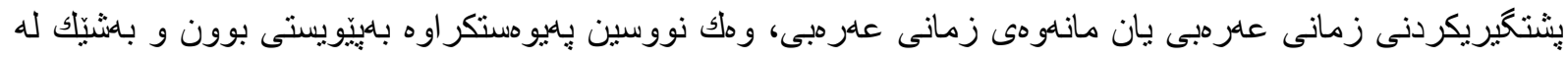

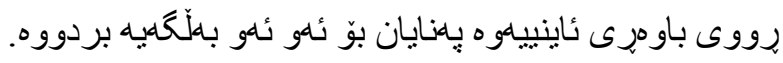

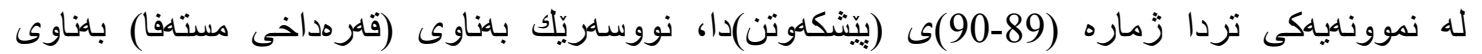

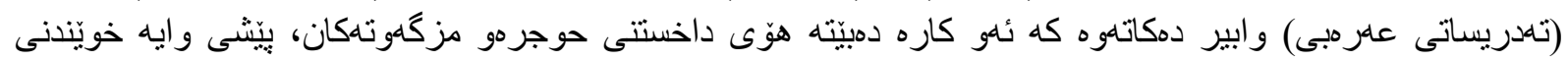

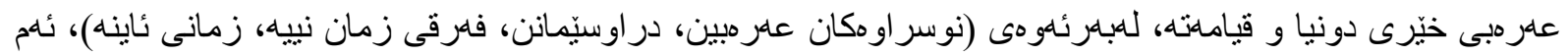

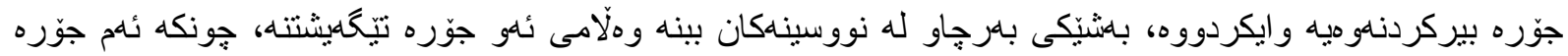

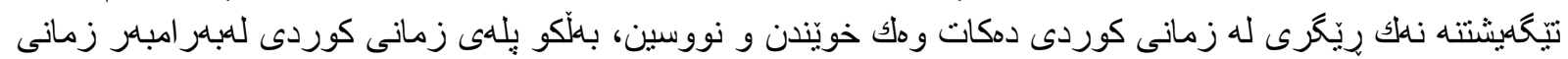

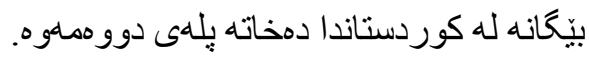

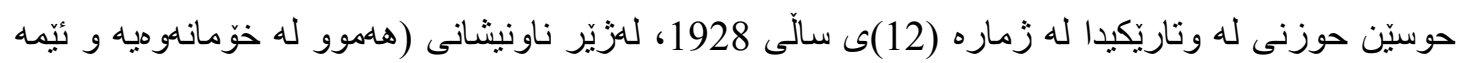

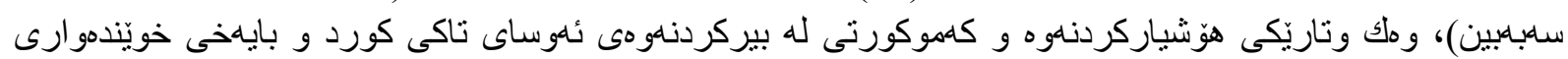

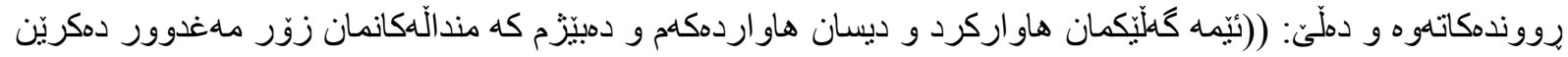

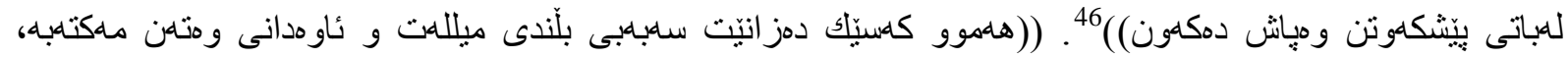

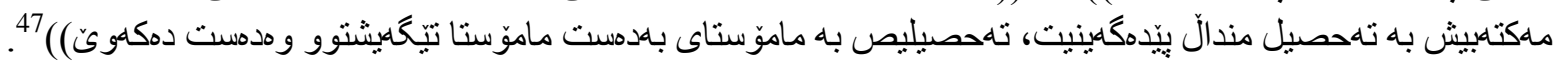

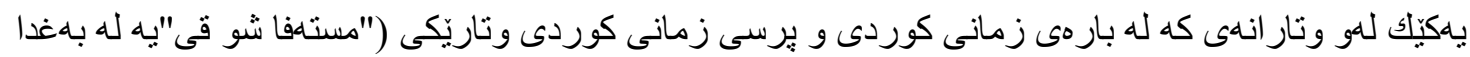

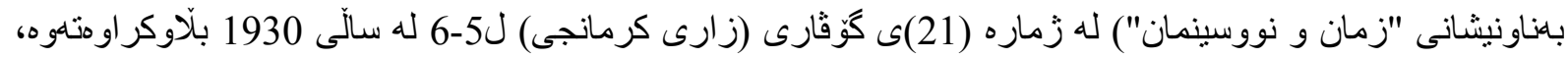




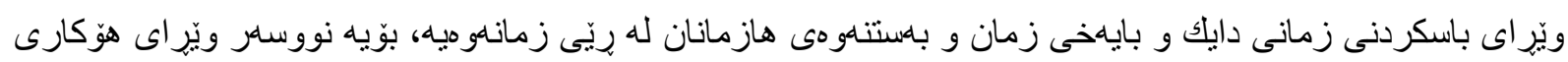

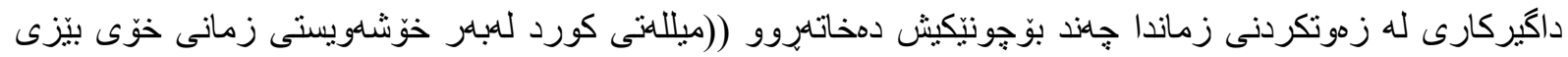

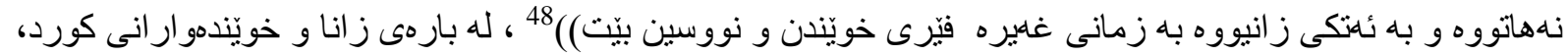

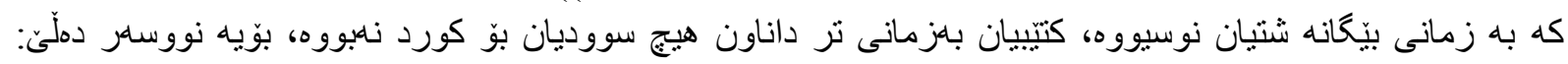

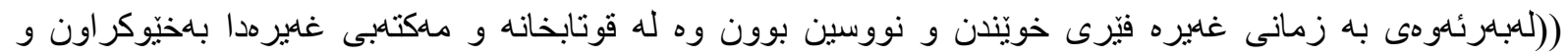

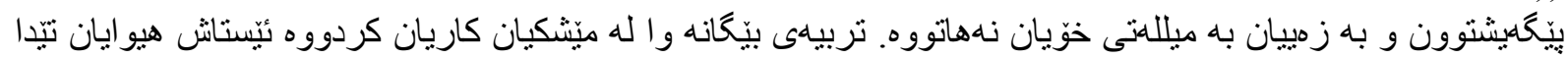

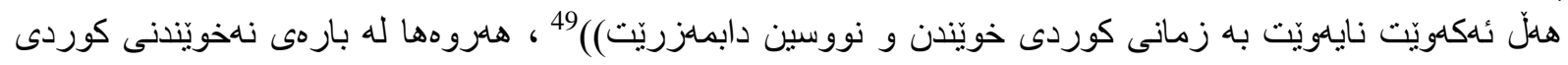

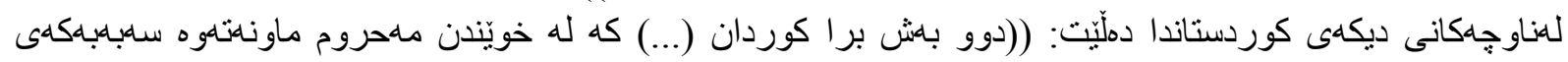

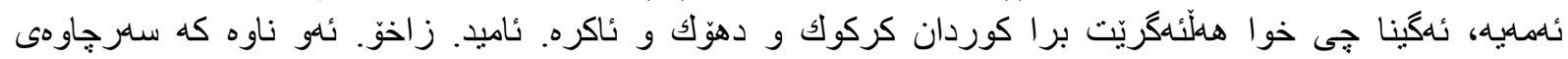

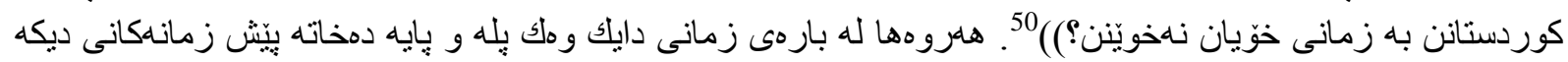

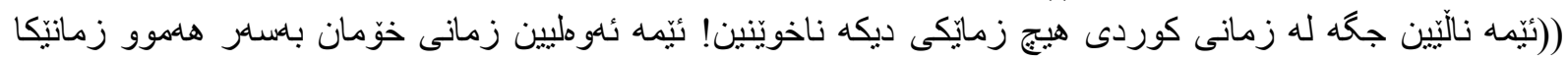

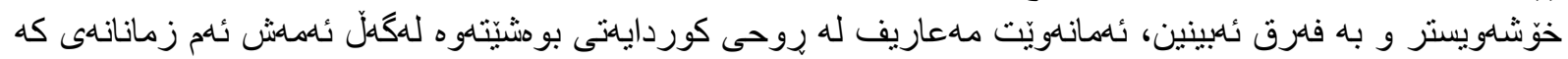

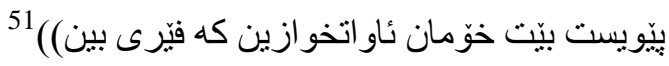

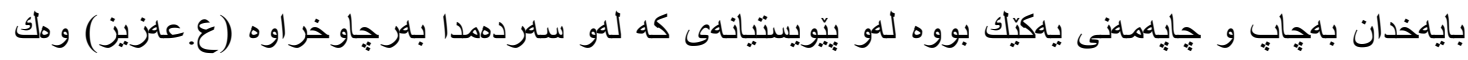

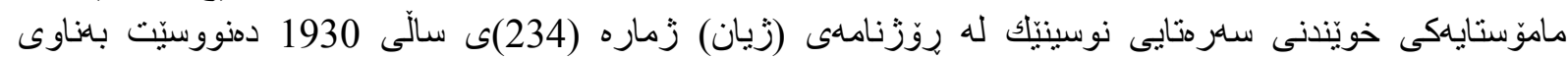

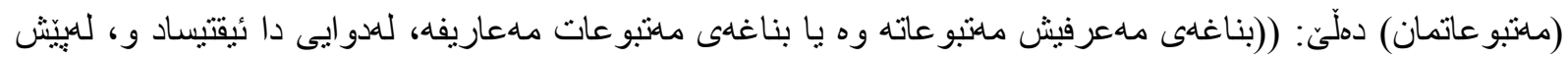

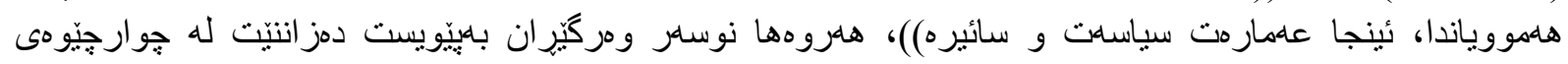

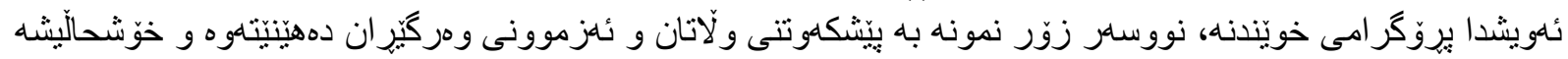

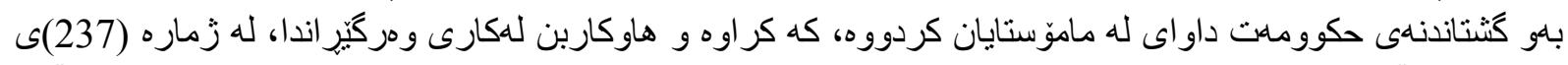

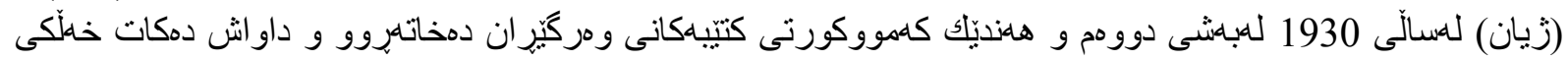

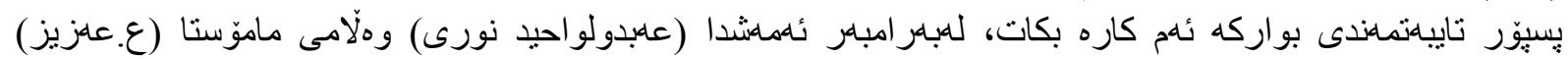

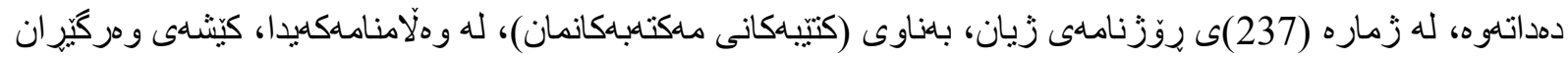

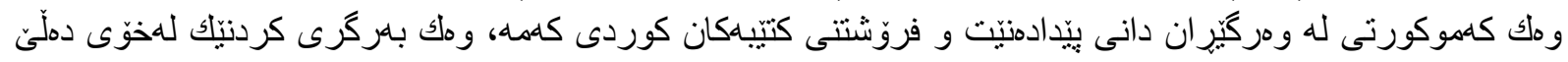

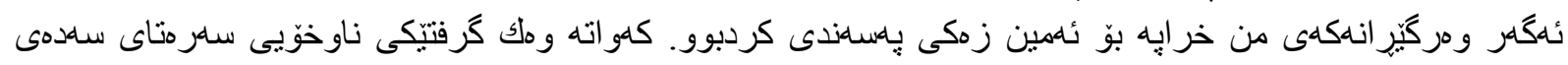

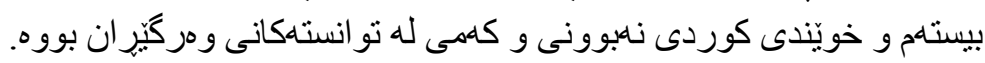

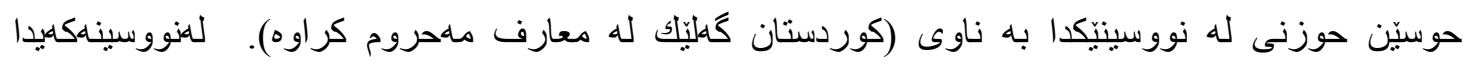

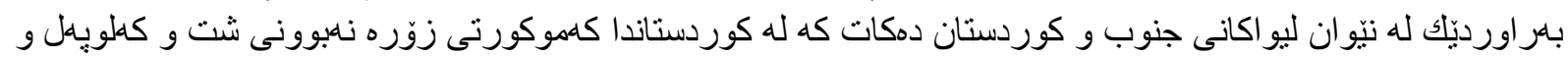

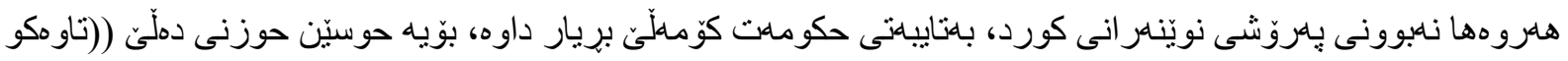

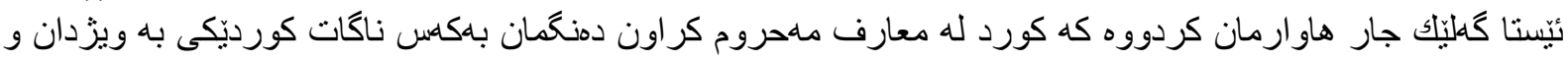

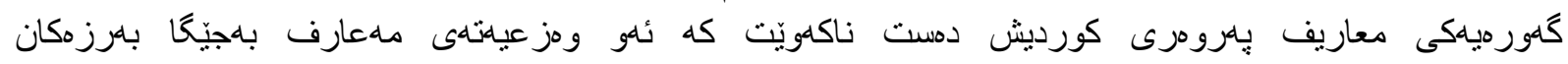

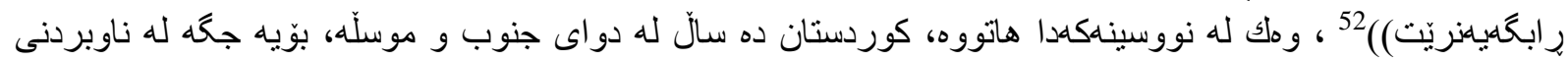

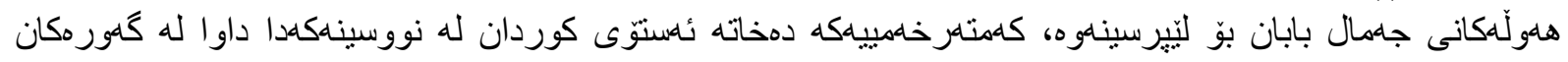

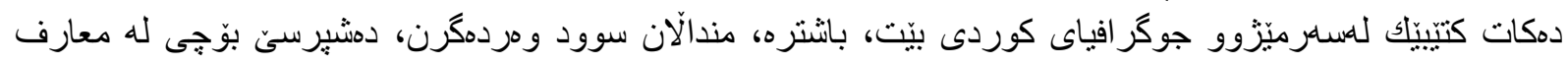
ئسمو انه قهبول ناكريّيت.

\section{هاندانى خويّندن و لابردنى ئاستهنحكهانى بهردهم خويّندن}

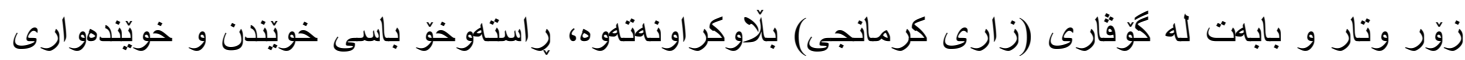

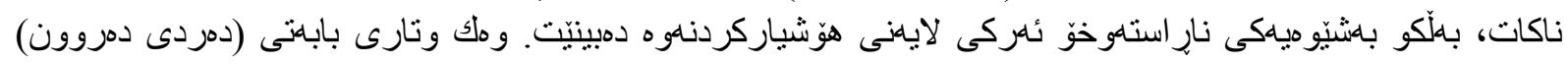

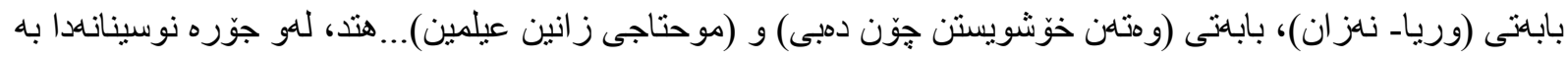

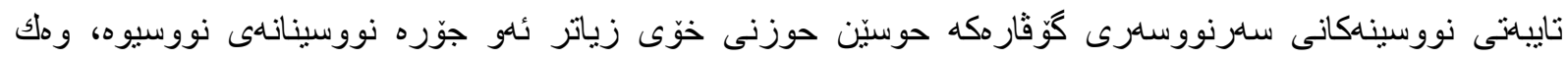

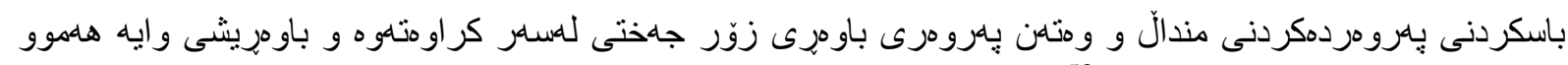

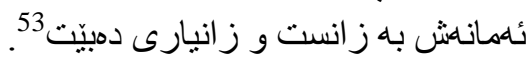




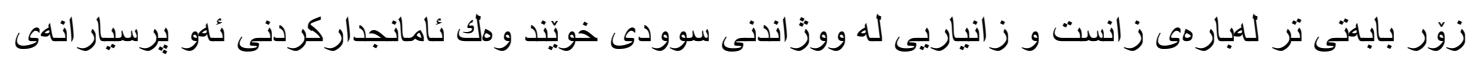

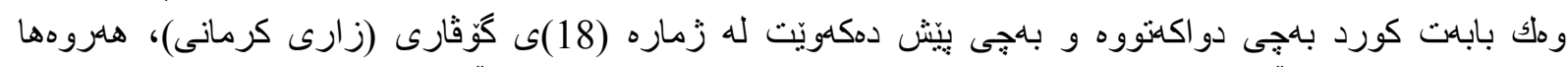

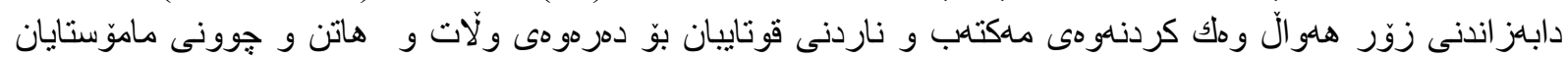

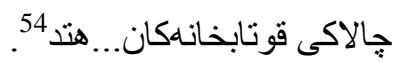

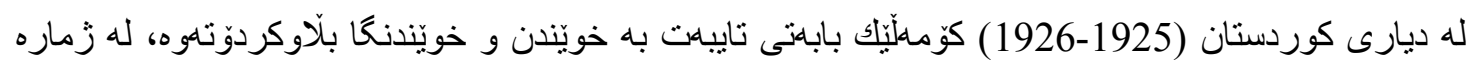

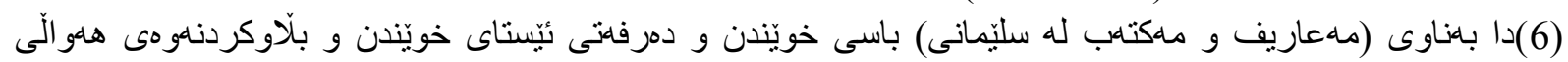

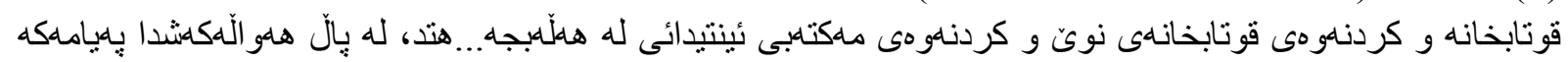

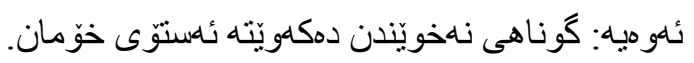

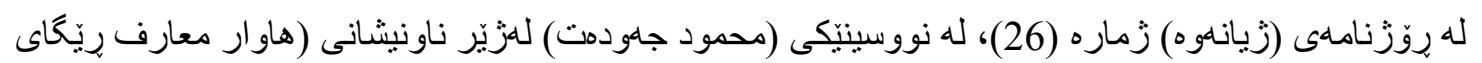

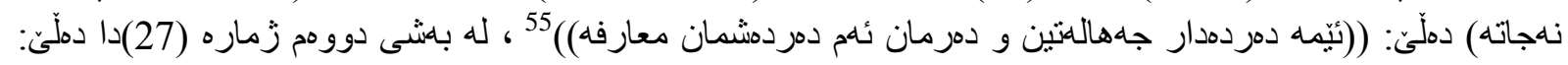

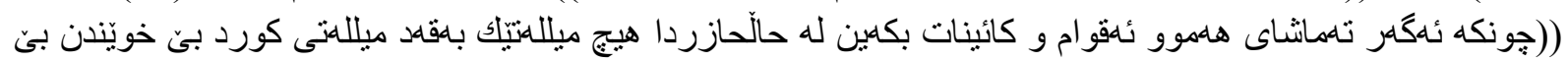

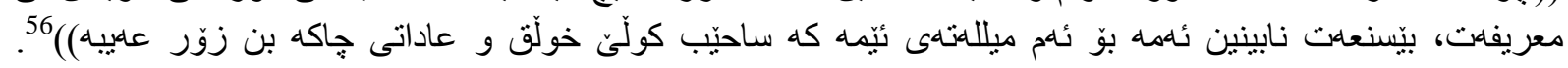

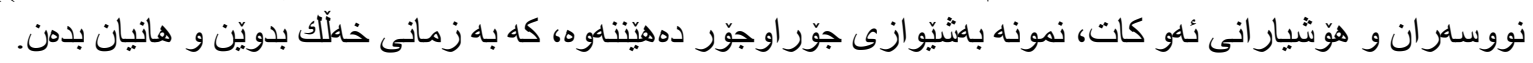

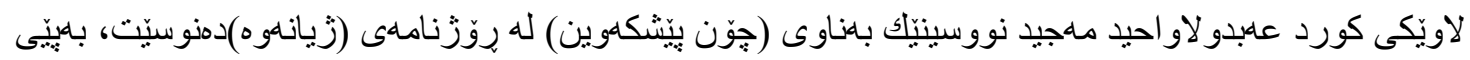

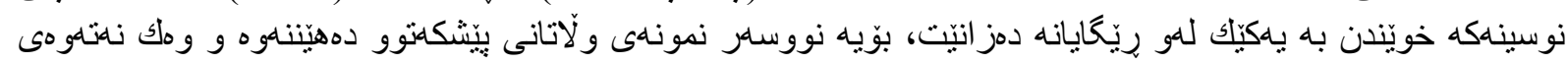

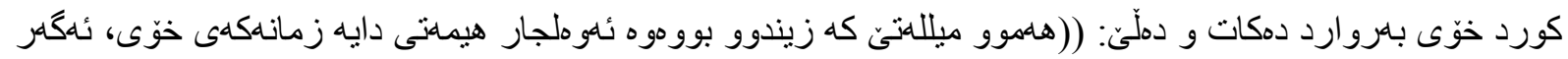

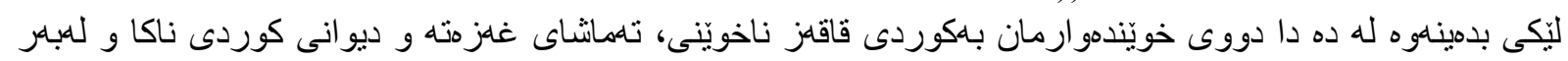

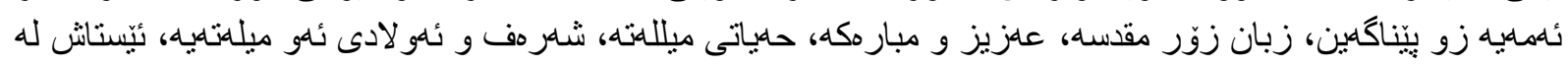

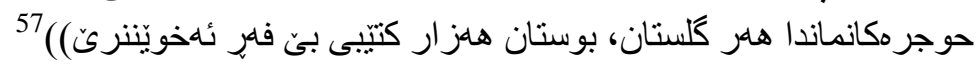

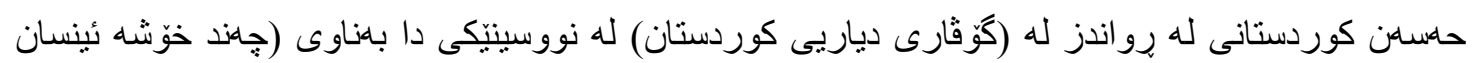

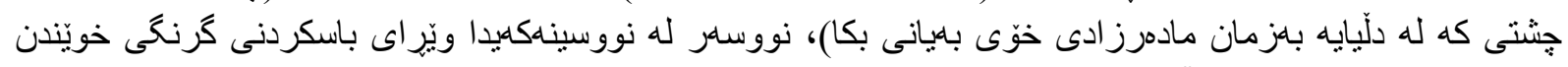

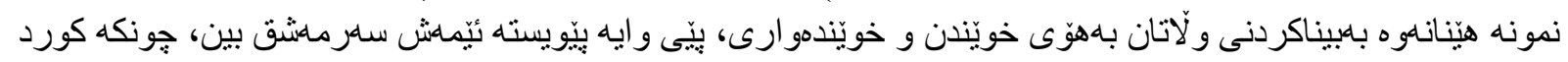

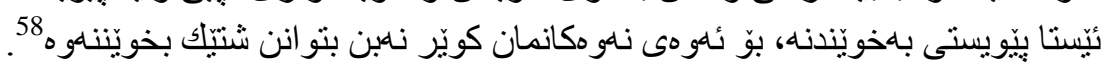

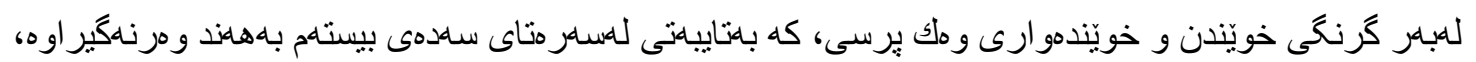

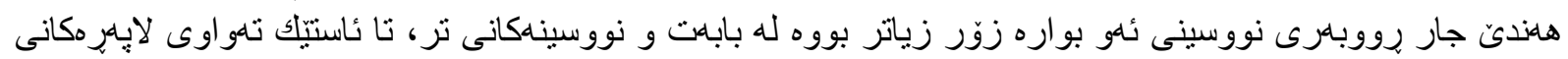

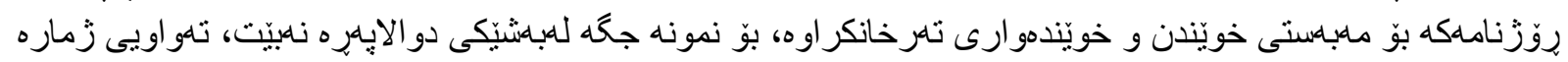

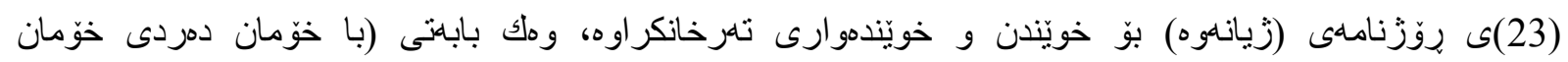

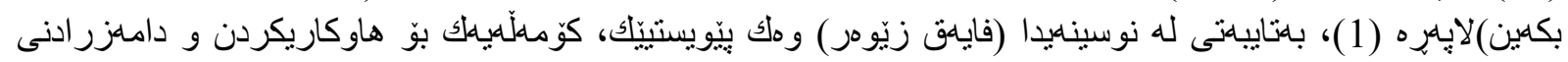

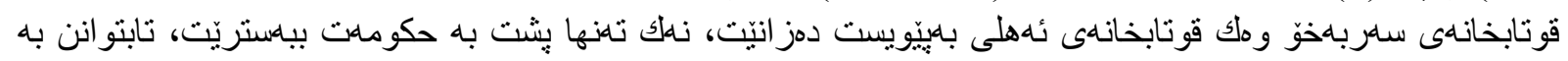

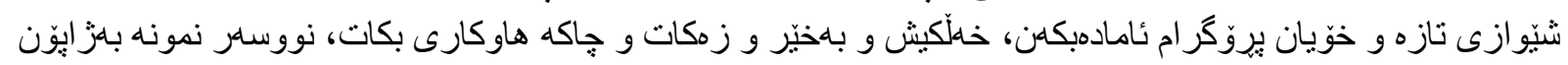

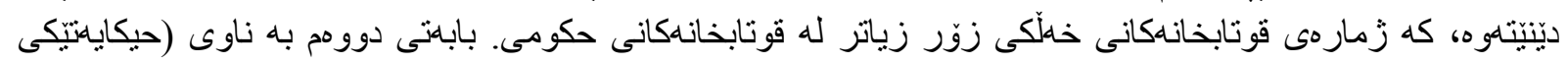

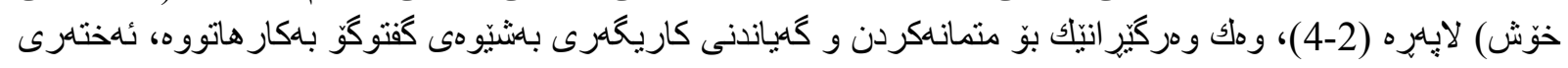

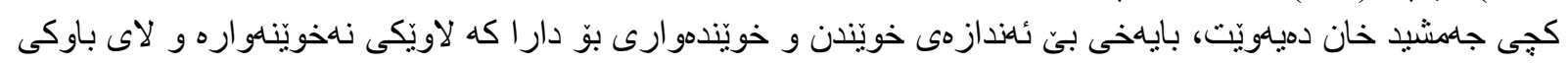

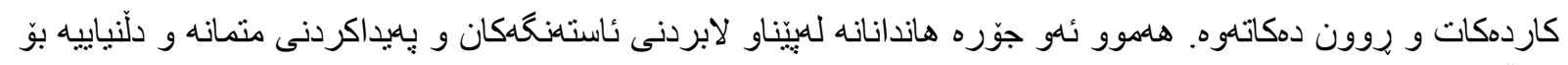
هاو لاتيان.

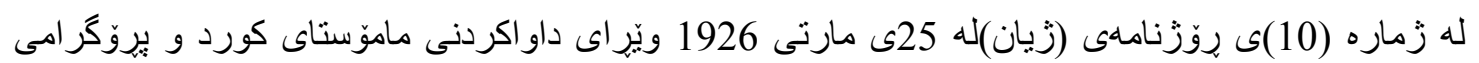

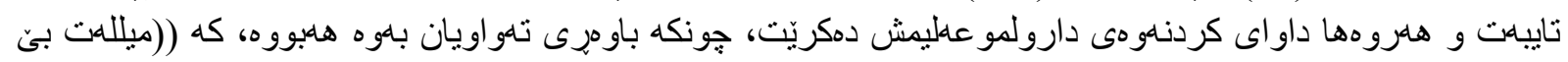

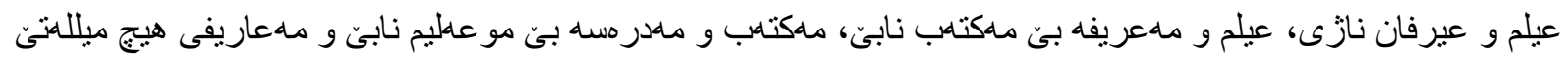

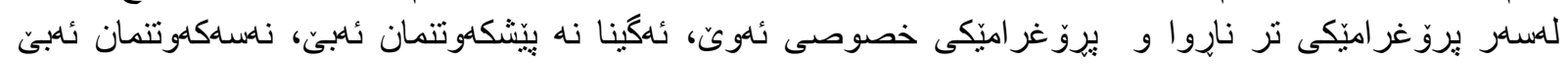

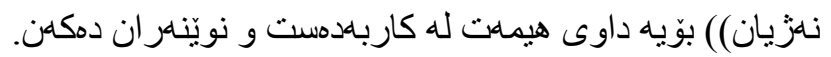




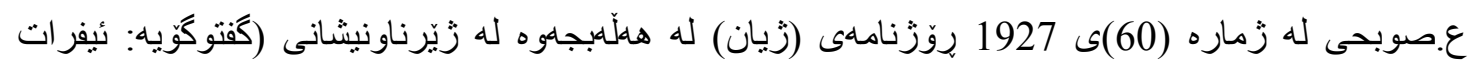

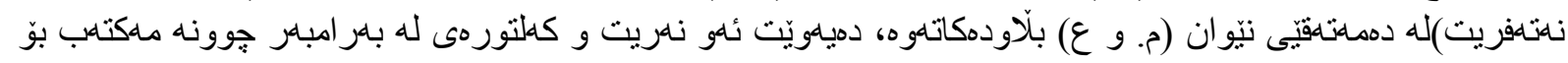

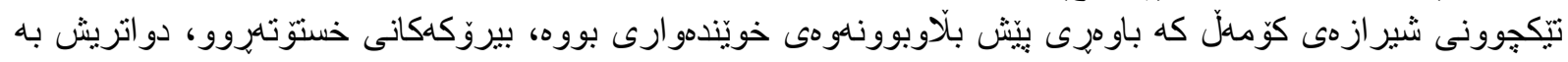

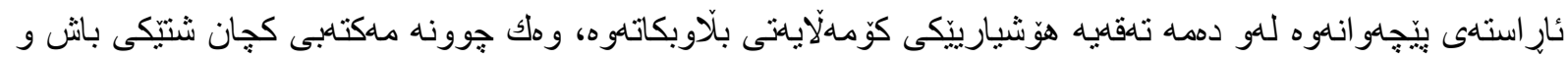
ئاساييه.

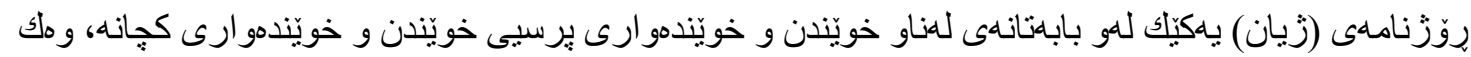

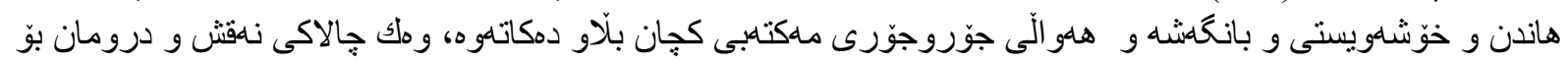

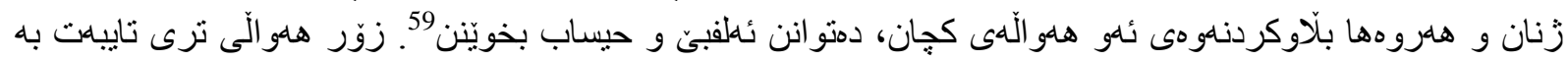

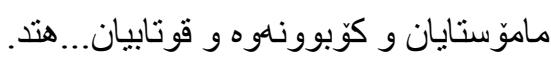

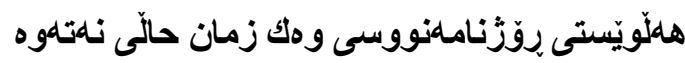

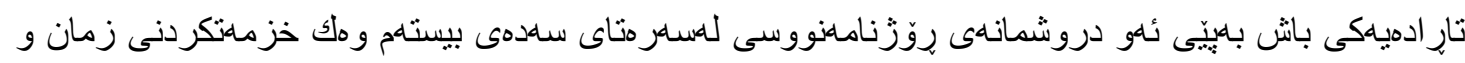

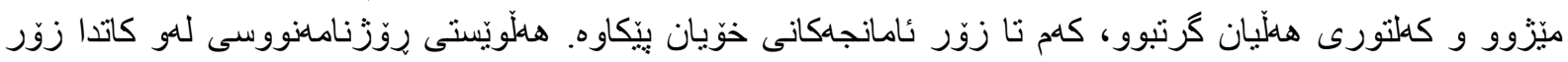

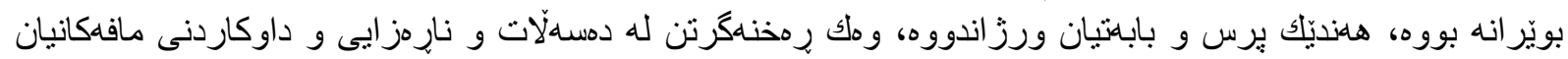

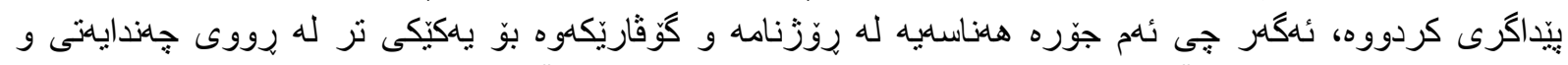

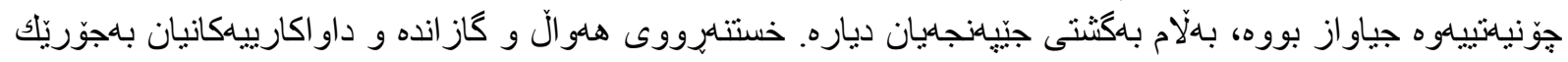

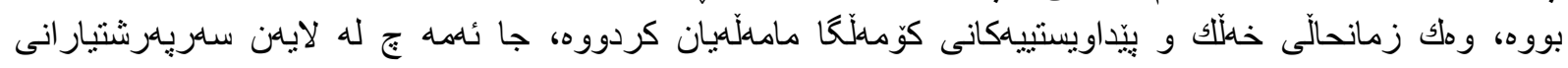

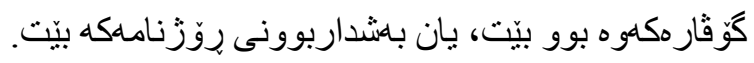

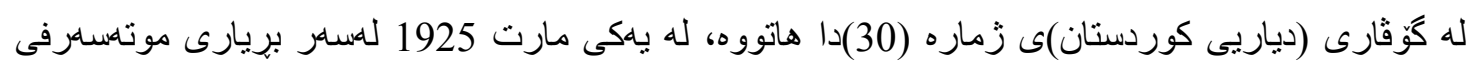

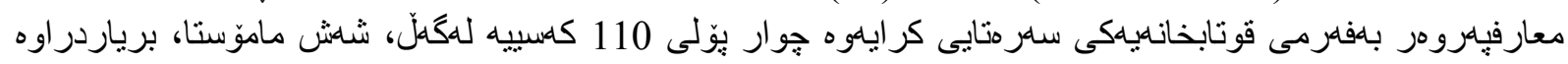

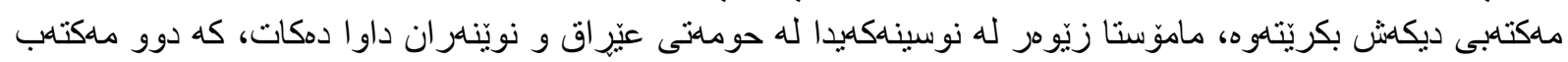

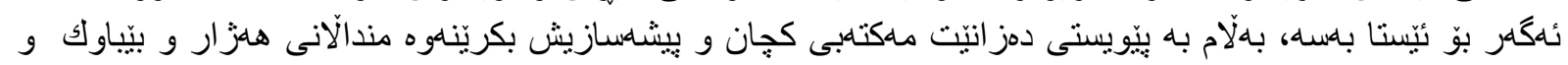

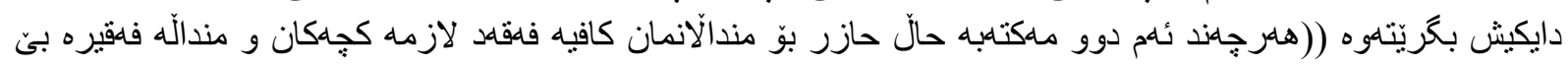

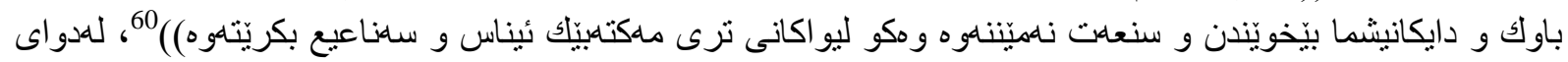

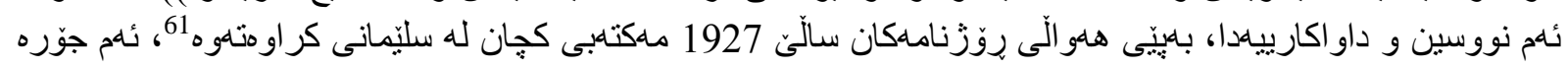

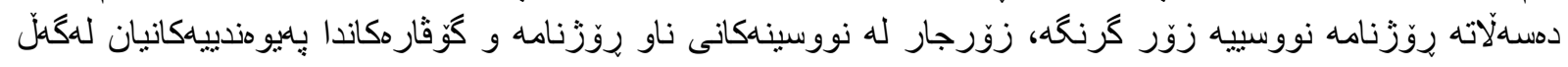

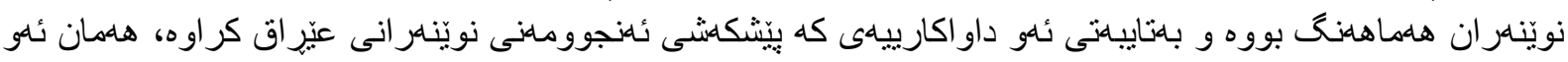

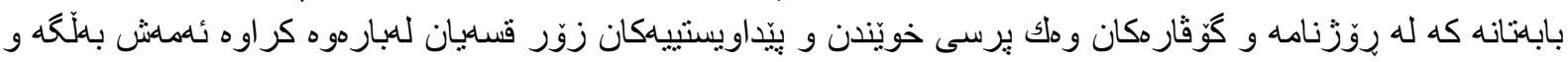

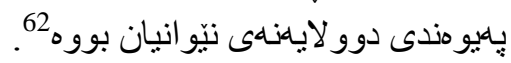

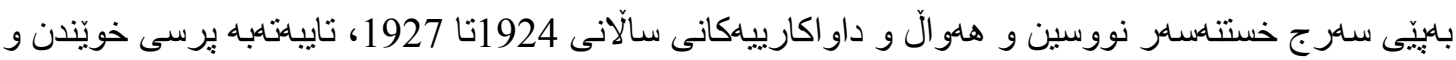

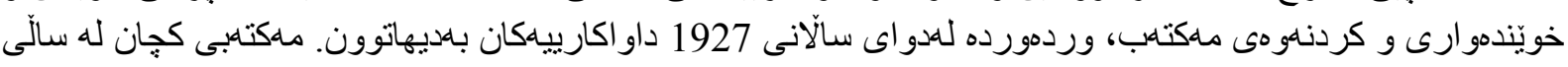

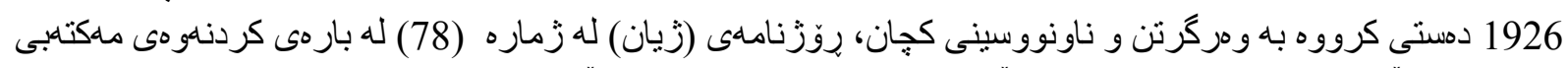

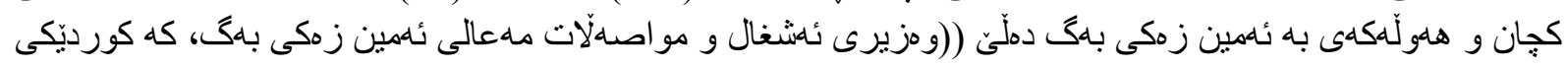

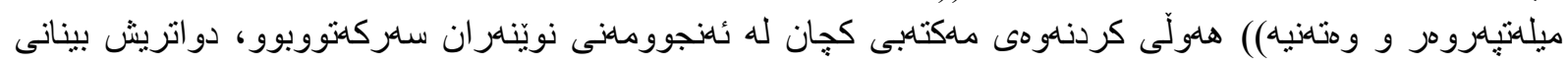

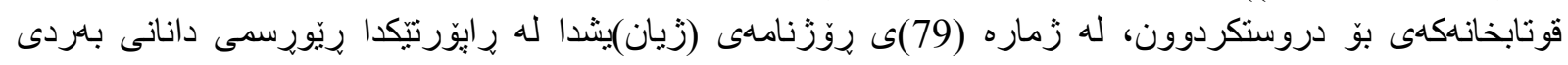

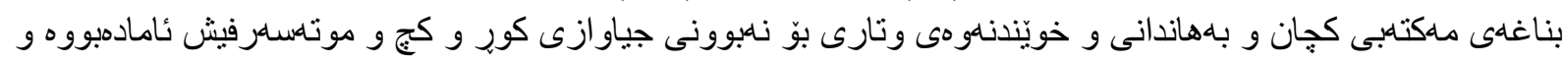

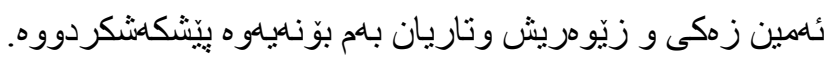

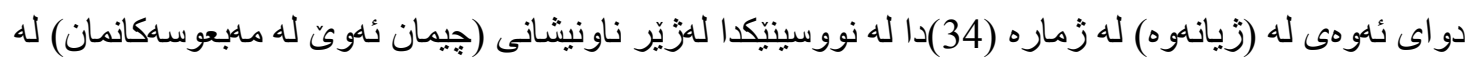

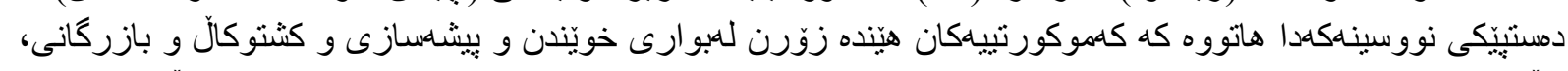

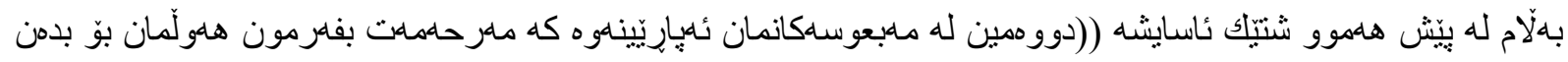

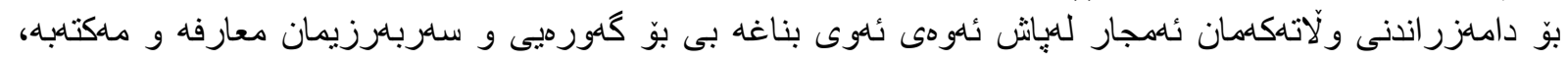




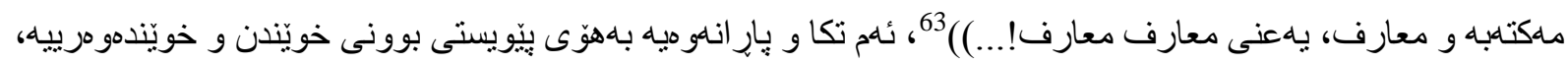

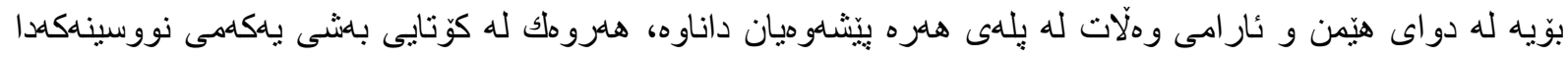

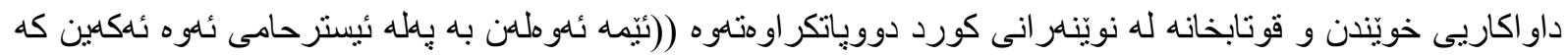

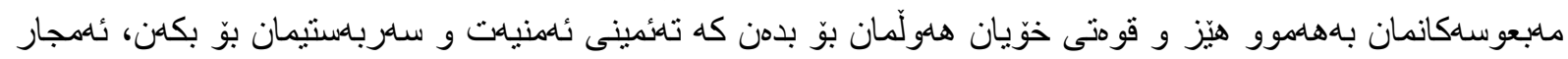

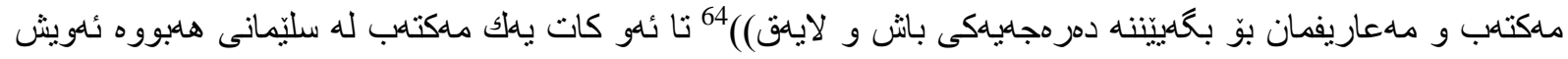

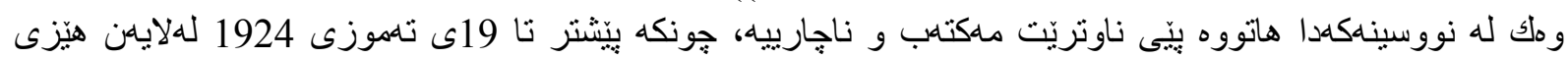

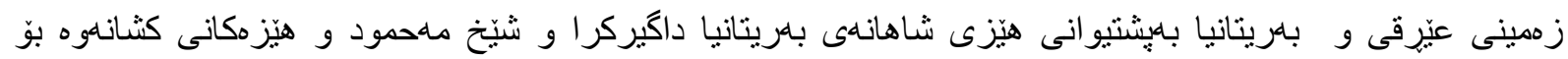

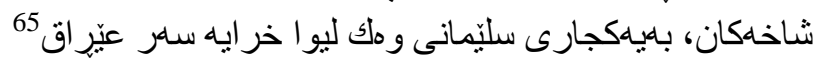

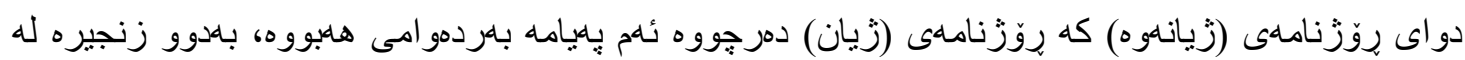

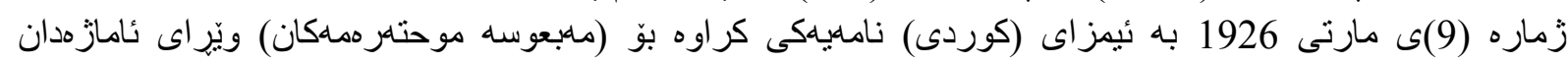

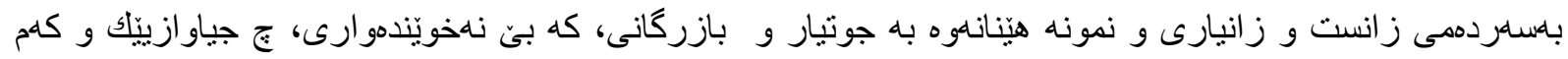

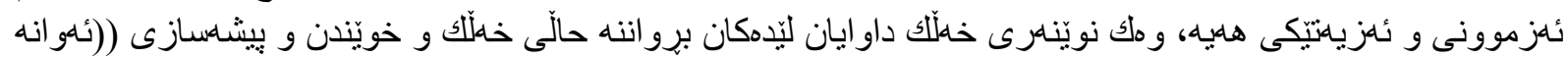

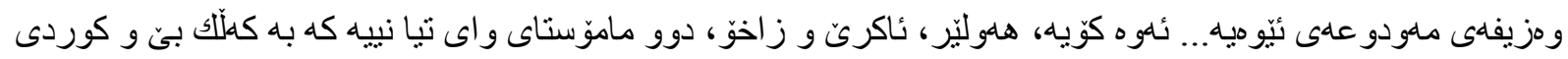

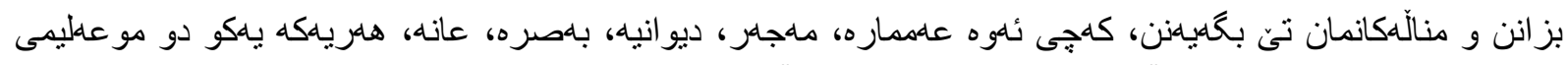

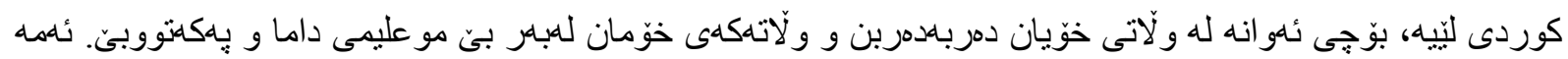

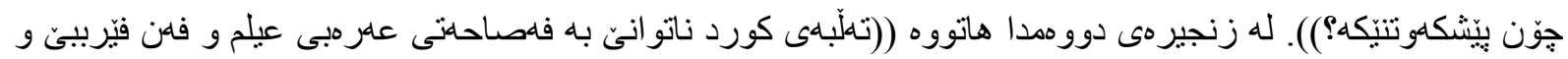

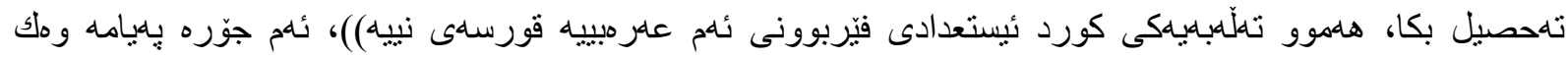

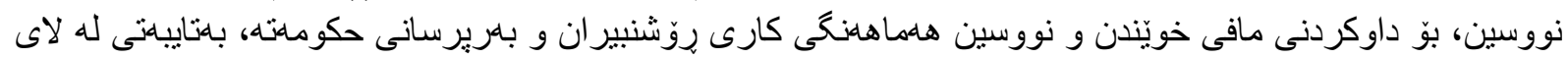

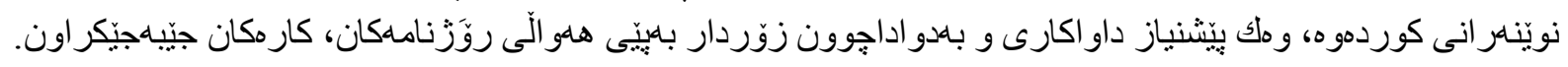

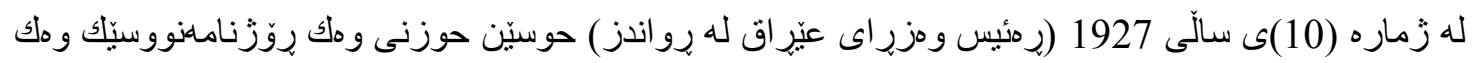

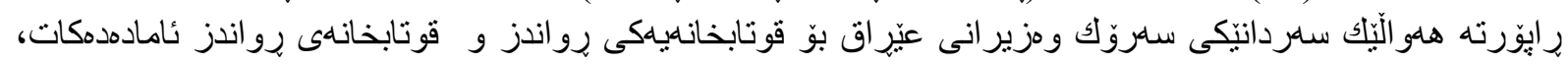

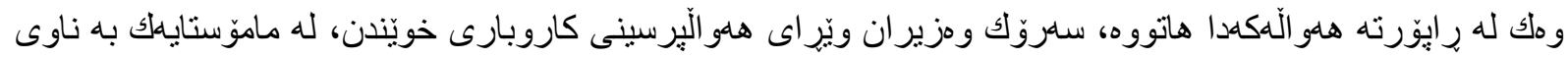

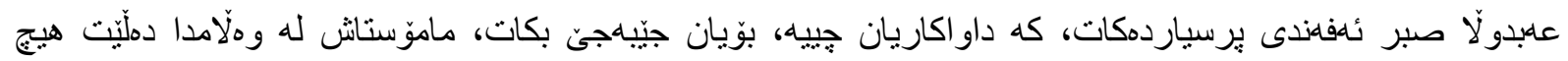

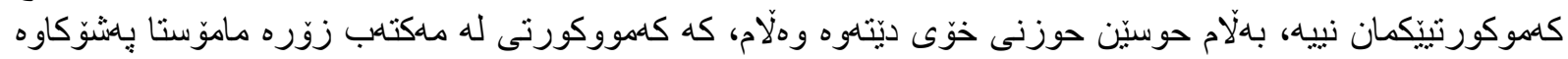

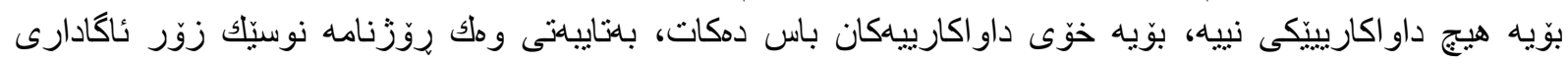

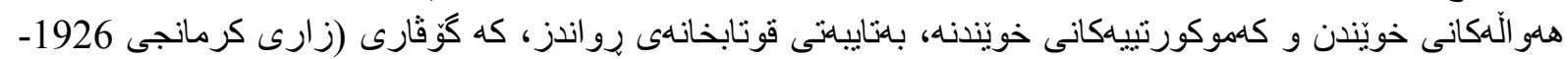

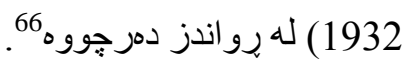

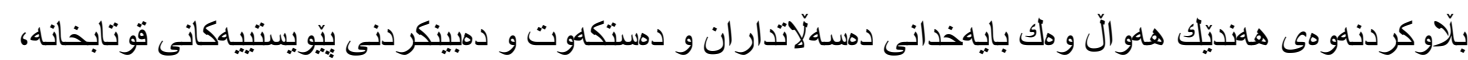

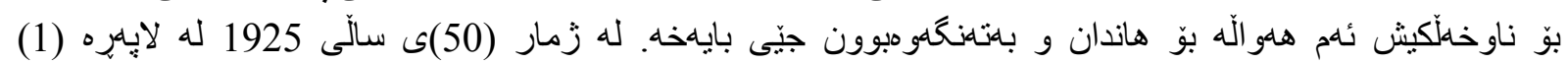

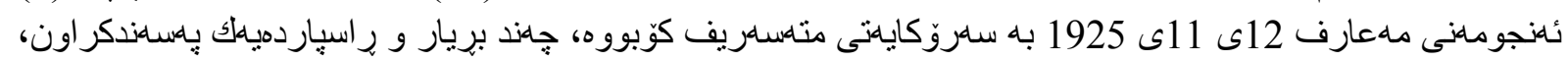

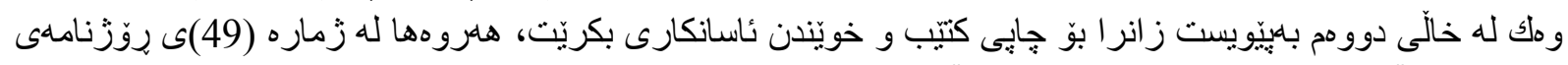

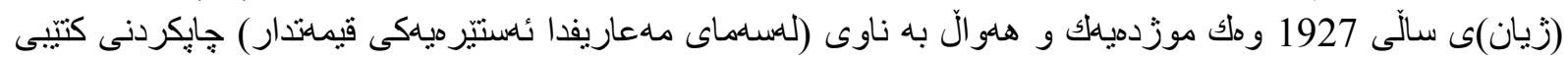

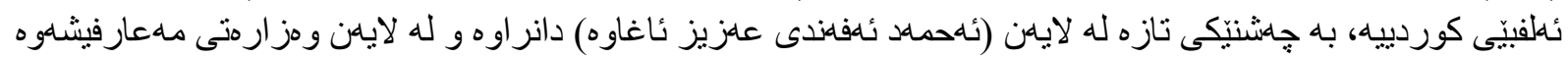

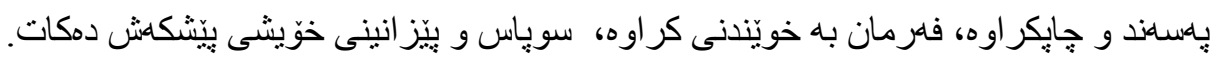

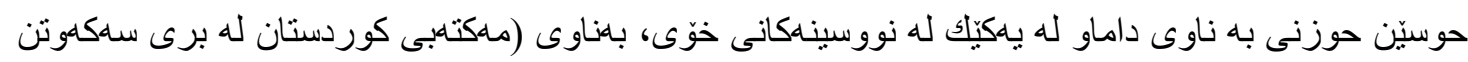

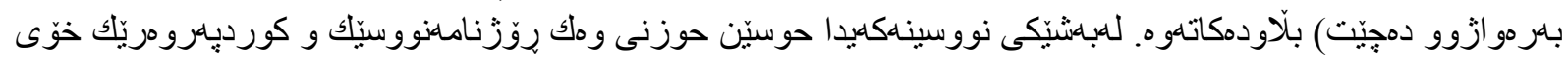

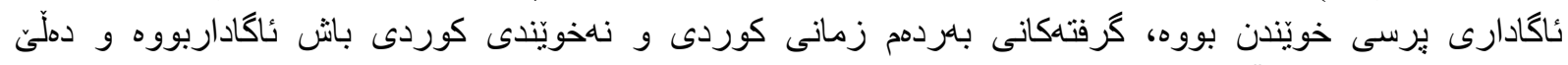

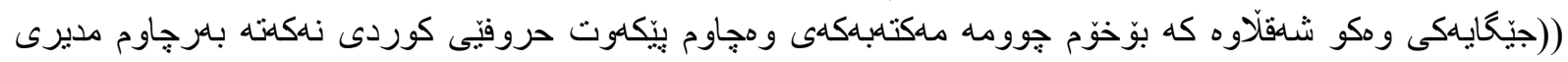

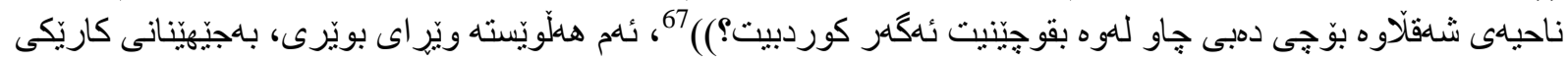

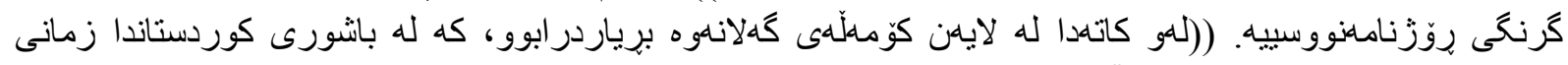

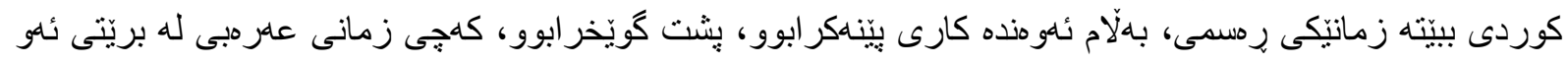




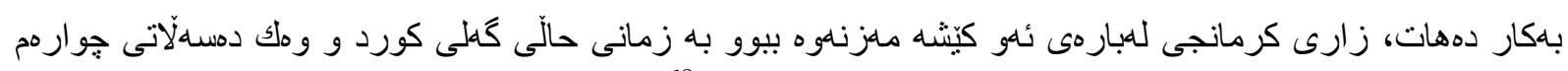

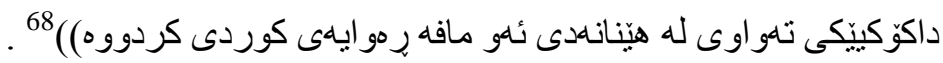

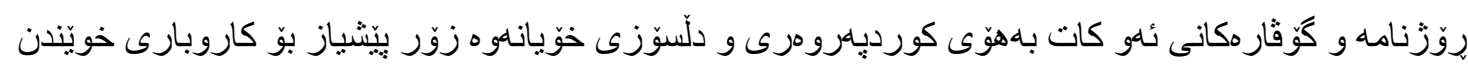

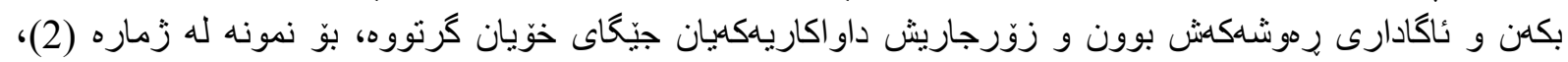

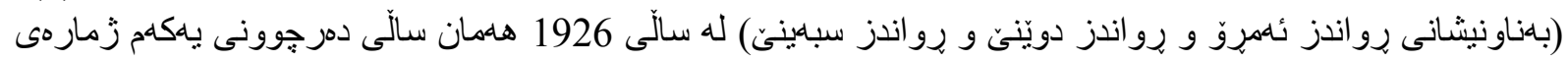

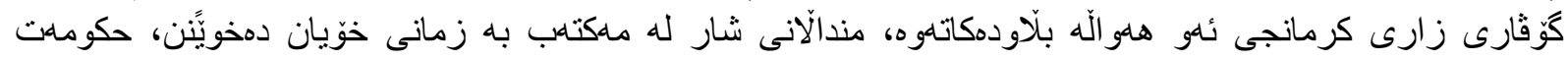

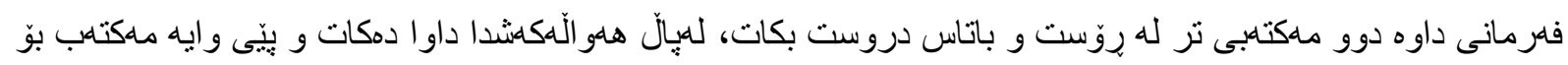

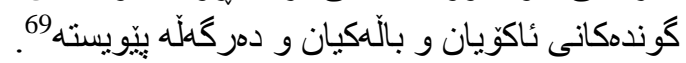

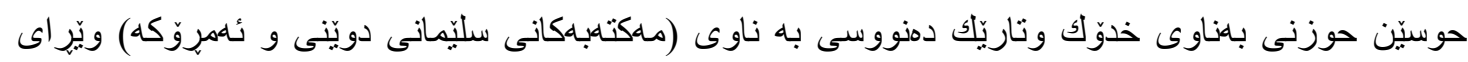

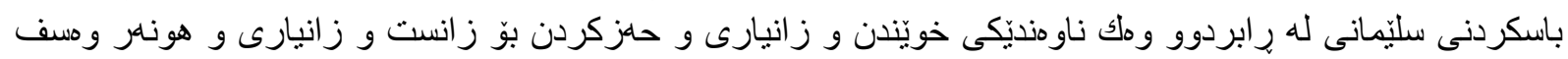

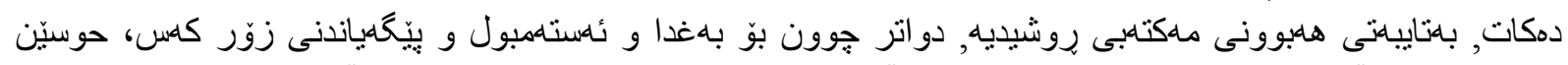

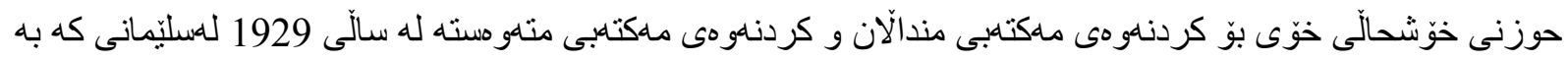

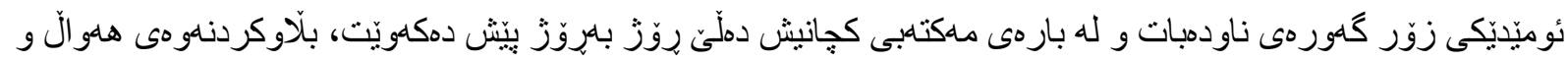

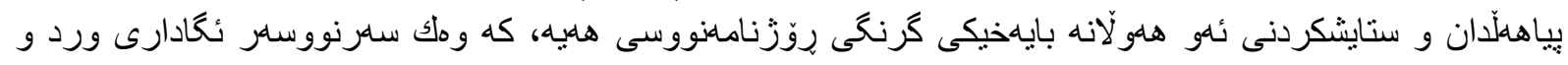

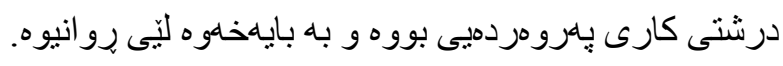

\section{أئنجام}

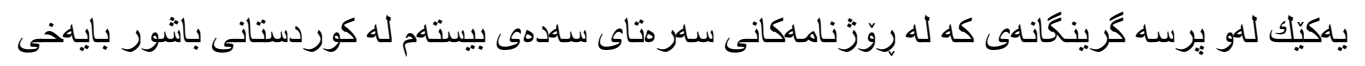

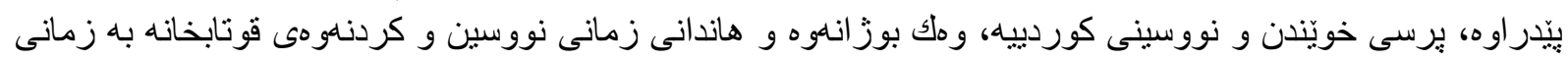

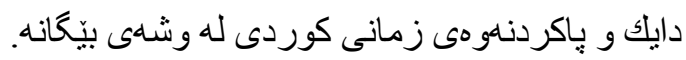

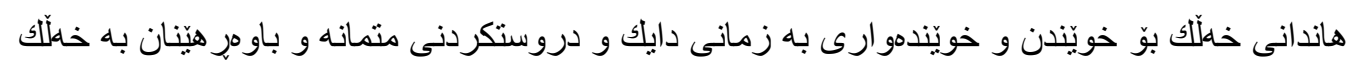

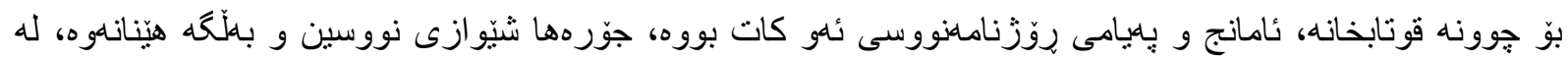

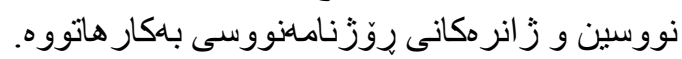

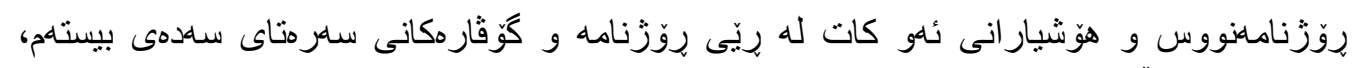

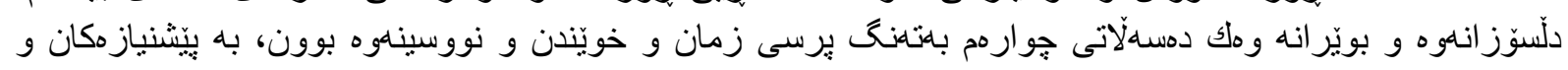

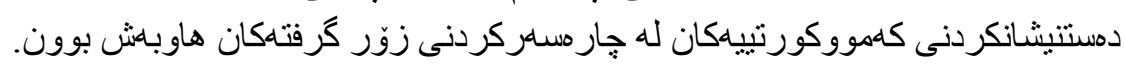

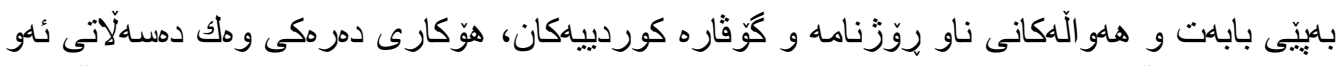

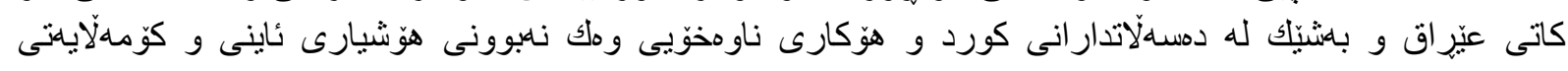

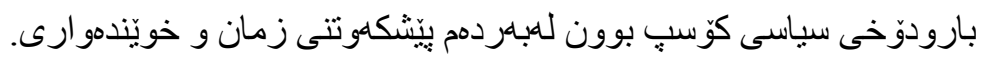

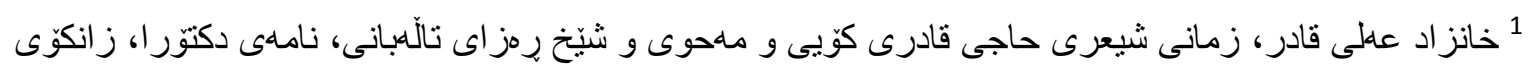

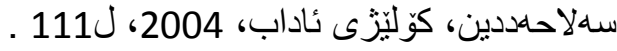

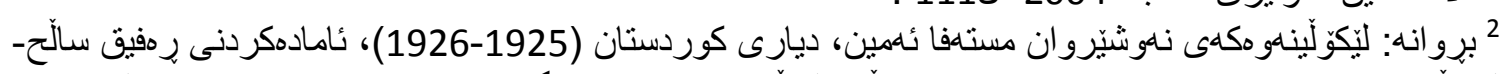

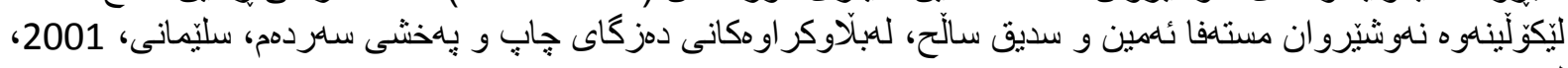

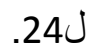

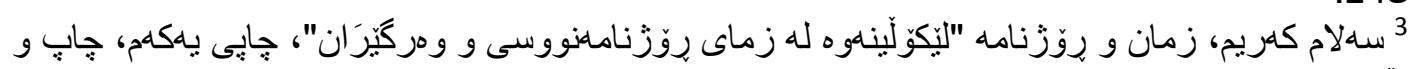

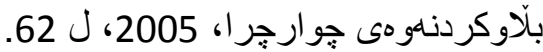

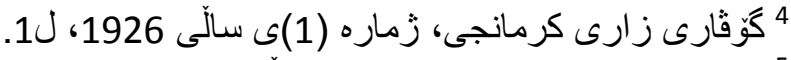

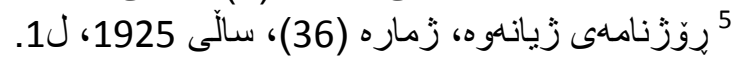




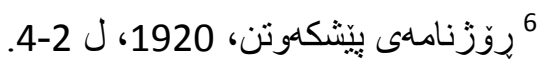

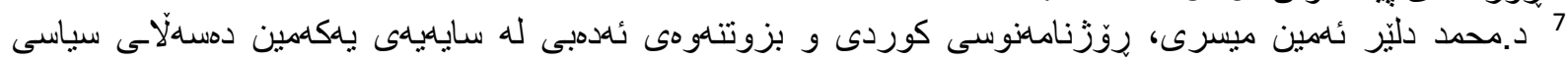

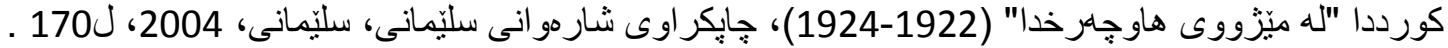

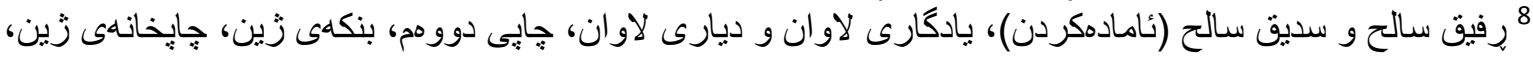

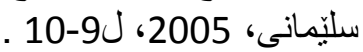

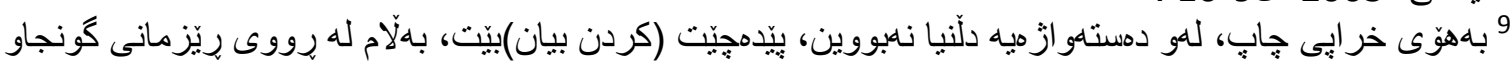

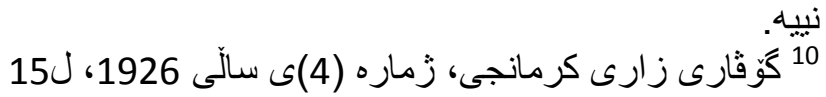

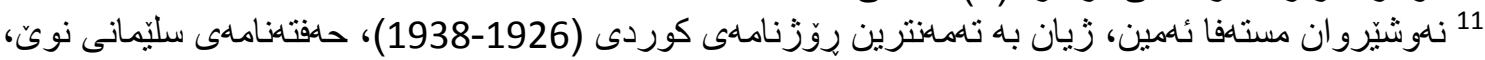

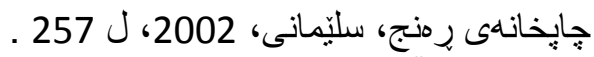

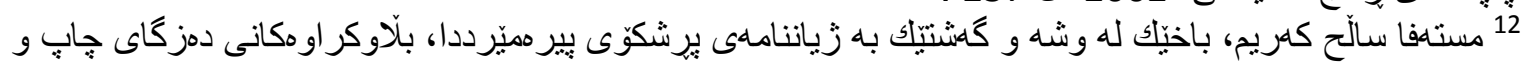

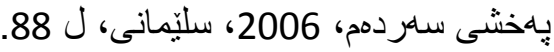

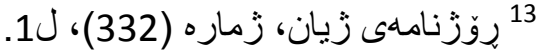

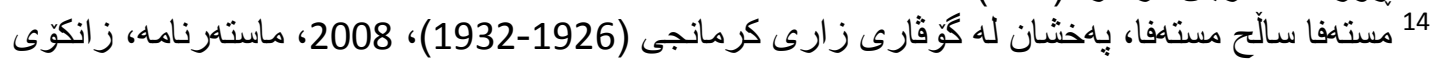

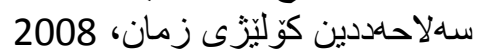

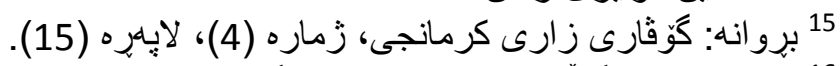

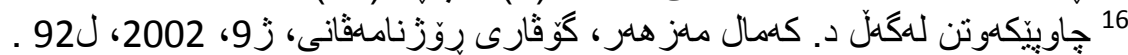

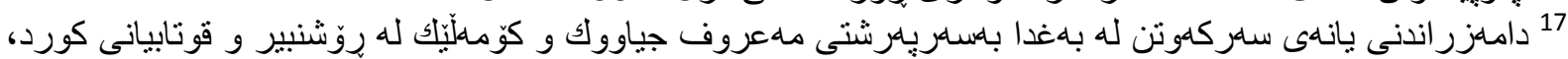

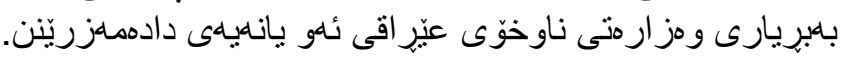

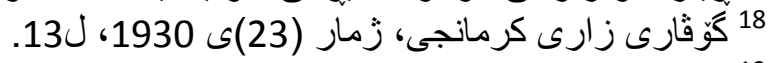

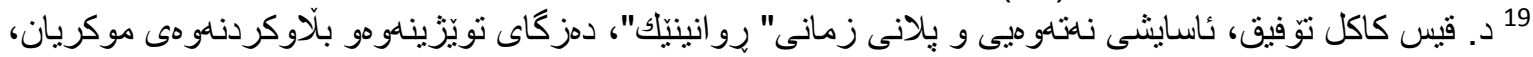

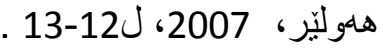

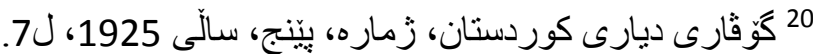

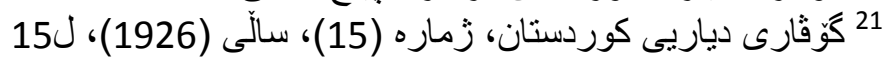

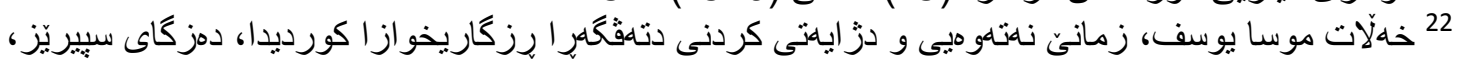

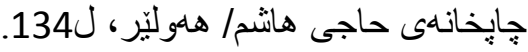
23 23

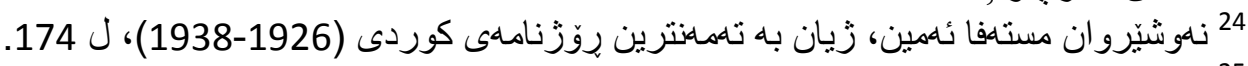

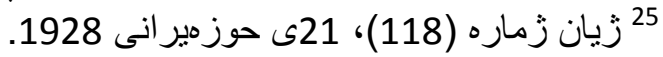

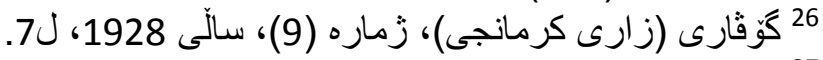

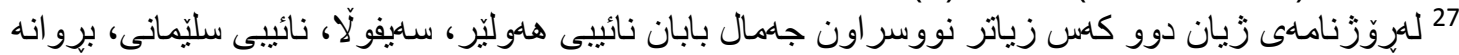

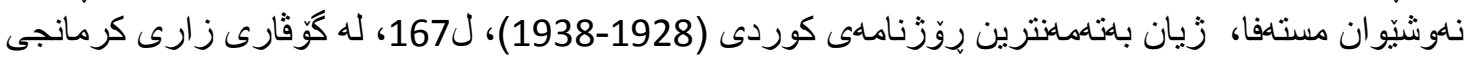

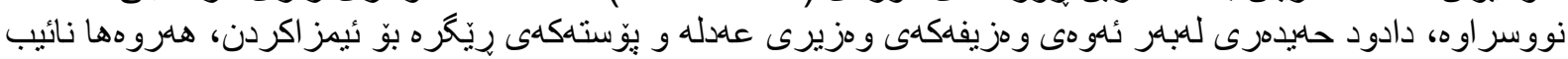

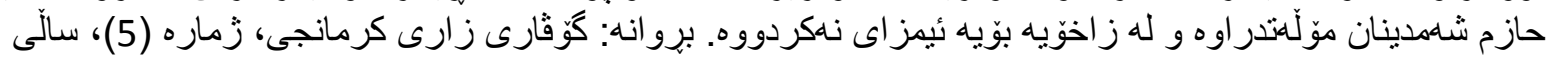

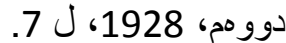

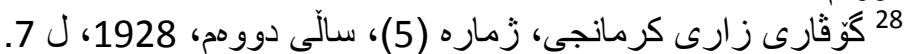

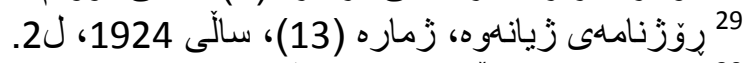

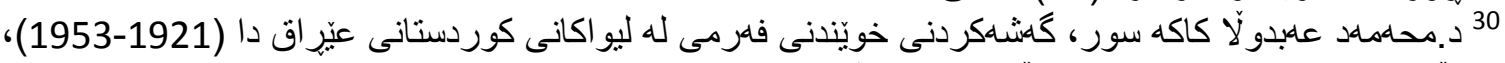

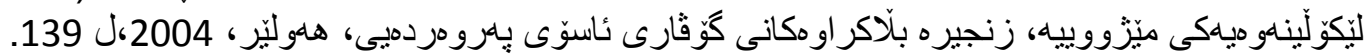
31

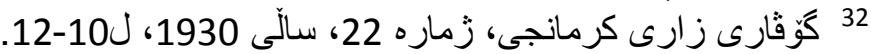

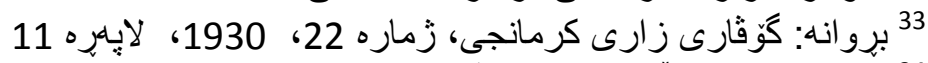

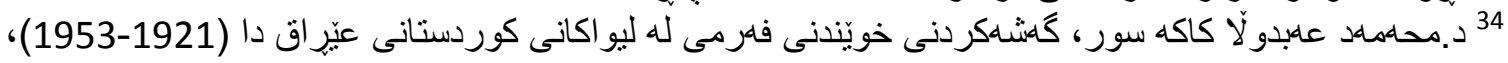
.65-64 J

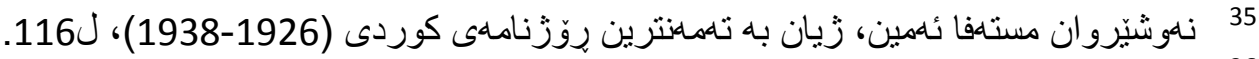
36 هلمان سامرجاوه، ل116. 


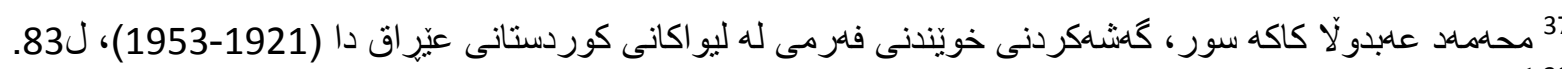

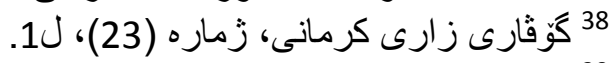

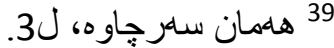

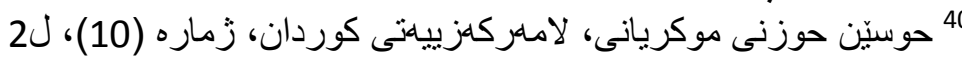
41 42 43

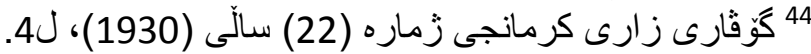

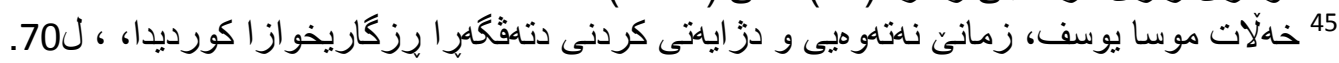

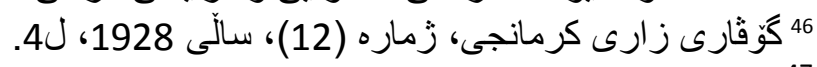

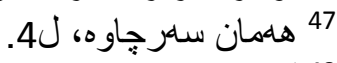

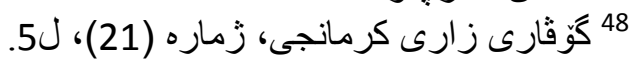

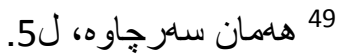

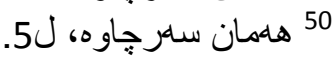
51

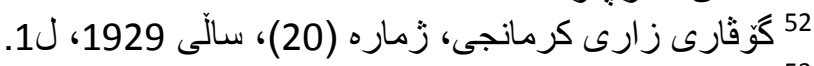

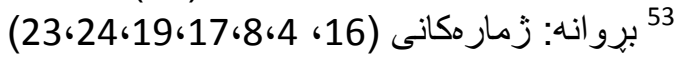

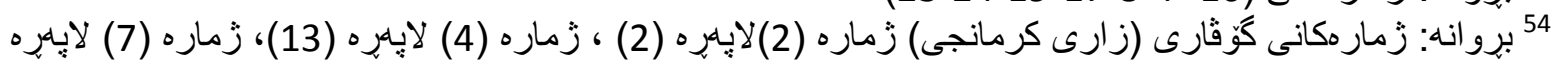

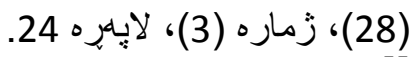

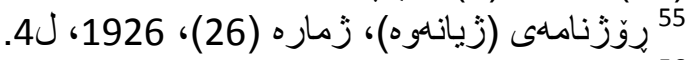

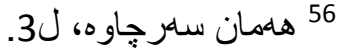

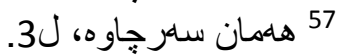

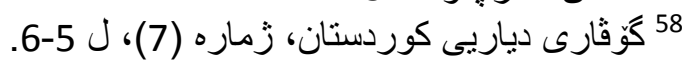

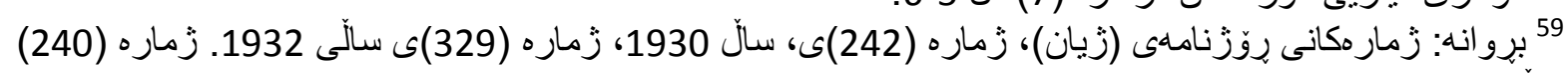

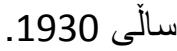

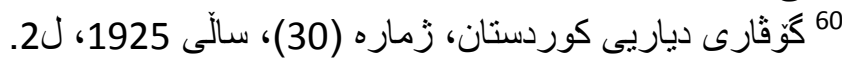

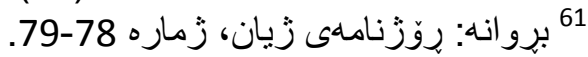

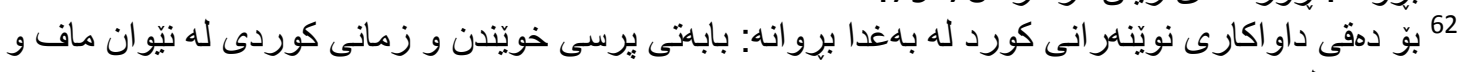

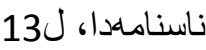

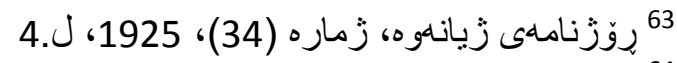

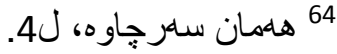

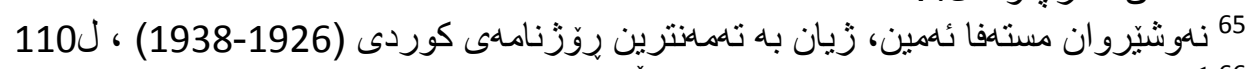

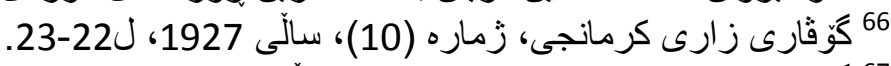

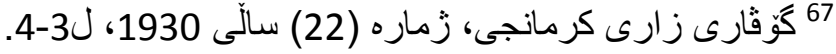

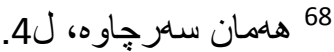

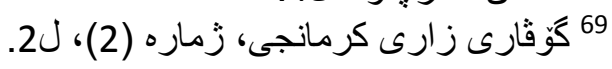

